Estudo para fabricação de refletores automobilísticos utilizando um material compósito termofixo e um material termoplástico

ELISEU WILLIAM DE SOUZA

Dissertação apresentada ao Instituto de Pesquisas Energéticas e Nucleares, Universidade de São Paulo, para obtenção do Título de Mestre em Materiais.

Orientador: Prof. Dr. Gerson Marinucci 


\section{AGRADECIMENTOS}

- A Deus, pelo dom da vida e pelas diversas oportunidades proporcionadas.

- Ao Prof. Dr. Gerson Marinucci, pela orientação, paciência, exemplo, apoio, ajuda e incentivo.

- À minha esposa Belzair e meus filhos Milena e Victor Hugo pela compreensão e pelo apoio.

- À minha mãe Izabel que sempre me incentivou na aplicação aos estudos.

- Ao amigo professor Marcio Claudino Gomes pela importante colaboração neste estudo.

- Aos colegas de trabalho: Wander Burielo de Souza, aos funcionários dos laboratórios do SENAI Mario Amato: Rosangela, Darilene, Kleber, Degmar e Wesley pela colaboração nos ensaios.

- Ao Prof. Dr. Carlos Augusto Xavier pela disponibilização dos moinhos de processamento de materiais cerâmicos.

- À Escola SENAI Mario Amato, todos os demais colegas e ao coordenador do Núcleo de Tecnologia do Plástico, professor Fabio Renato Lopes pela liberação dos equipamentos para a realização dos ensaios.

- À empresa Braskem e ao Lauro Lobato pela colaboração no processamento de material e nos ensaios realizados.

- Ao corpo docente do IPEN pela passagem dos diversos conteúdos. 


\title{
ESTUDO PARA FABRICAÇÃO DE REFLETORES AUTOMOBILÍSTICOS UTILIZANDO UM MATERIAL COMPÓSITO TERMOFIXO E UM MATERIAL TERMOPLÁSTICO
}

\author{
ELISEU WILLIAM DE SOUZA
}

\section{RESUMO}

$\mathrm{Na}$ montagem de um farol automobilístico são utilizados diversos materiais, tais como insertos metálicos nas fixações, vidros nas lâmpadas, materiais poliméricos nas lentes, carcaças, molduras, vedações e refletores, além de vernizes, tintas, película de metal para reflexão do feixe luminoso.

Há cerca de quatro décadas foi iniciada a confecção dos refletores utilizando o BMC (bulk moulding compound), sigla em inglês para composto para moldagem em forma de massa, que é um compósito polimérico termofixo. Este material apresenta inúmeras vantagens sobre o metal, tal como forma e geometria que podem se integrar facilmente ao desenho do carro, elevada produtividade, baixo custo e da elevada resistência térmica. Contudo, apresentam o inconveniente de não poderem ser reciclados.

Uma opção ao BMC tem sido o PEI [poli (éter imida)], que é um material polimérico termoplástico de alto desempenho que apresenta propriedades atrativas para essa utilização. Oferece também elevada produtividade, porém com um custo elevado se comparado ao BMC. Tem a vantagem de pode ser reciclado.

De modo a analisar o potencial dos dois materiais e extrair deles suas vantagens competitivas, bem como determinar suas possíveis limitações, o presente trabalho apresenta os resultados de caracterização mecânica, análise térmica, ensaios de impacto, ensaios de temperatura de deflexão térmica (HDT) e reaproveitamento de resíduos de BMC, incorporando-o ao PVC [poli (cloreto de vinila)], resultando uma nova blenda polimérica.

$O$ estudo conclui que ambos os materiais podem ser utilizados para fabricação de refletores automobilísticos. No entanto, o preço do PEl é maior que o do BMC, o que desestimula sua utilização em produtos de alta escala de produção, como, por exemplo, o produto do presente trabalho. O BMC por sua vez não pode ser reciclado, exigindo um custo adicional para seu reaproveitamento de maneira a evitar seu descarte em aterro sanitário. 


\title{
STUDY FOR MANUFACTURING AUTOMOBILE REFLECTORS USING A THERMOSET COMPOSITE MATERIAL AND A THERMOPLASTIC MATERIAL
}

\author{
ELISEU WILLIAM DE SOUZA
}

\section{ABSTRATCT}

For assembly of an automobile headlight a lot of materials are used such as metallic inserts anchors, glass in the lamps, lens of polymeric materials, bezels, frames, fences and reflectors as well as paints, metallic sheet for reflection of the luminous beam.

About four decades ago begun the manufacturing of BMC reflectors, which is a thermoset composite material. This material presents countless advantages on the metal, such as shape and geometry that can easily integrate the designing of cars, high productivity, low cost and high heat resistance. However, they have the disadvantage of not being able to be recycled.

An option to the BMC has been the PEI [poly (ether imide)], which is a high performance polymeric thermoplastic material which brings attractive properties for the production of reflectors. It also offers high productivity, however with a high cost compared to BMC. It also has the advantage of being recycled.

In order to analyze the potential of both materials and extract their competitive advantages, as well as determine their possible limitations, this study presents the results of mechanical characterization, thermal analysis, impact tests, tests on heat deflection temperature (HDT) and the reuse of BMC waste, incorporating it to PVC [poly (vinyl chloride)], resulting in a new polymeric blend.

The study concludes that both materials can be used for manufacturing automobile reflectors. However, the price of PEI is higher than the one of BMC, which discourages their use in high-scale production products, as the one of this work. The BMC for your time can not be recycled, demanding an extra cost for their reuse, avoiding its disposal in landfill. 


\section{SUMÁRIO}

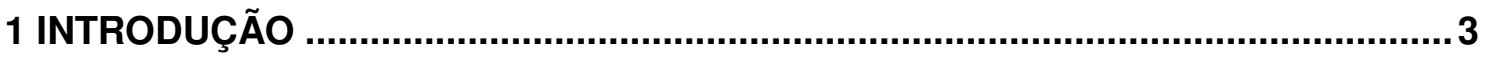

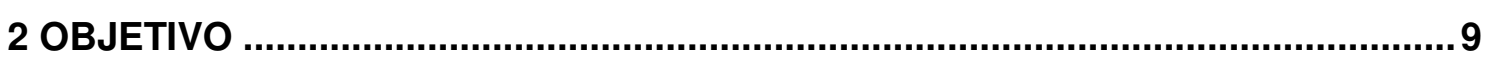

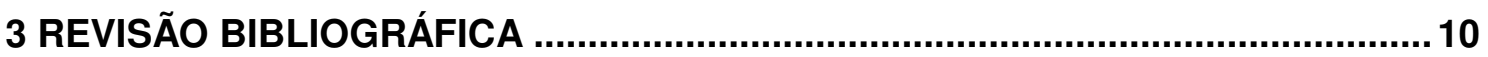

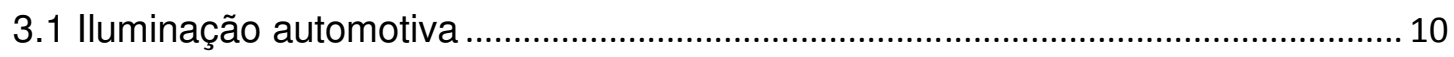

3.2 Materiais termofixos e a indústria automobilística................................................. 12

4 ABORDAGEM TEÓRICA ............................................................................... 14

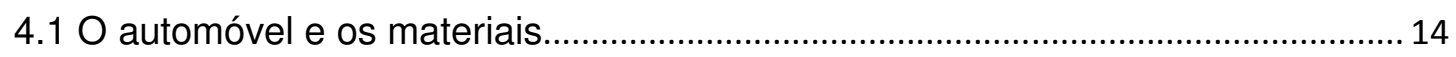

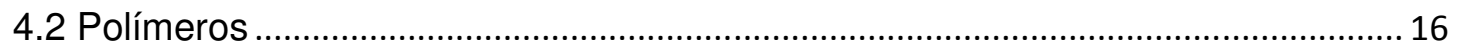

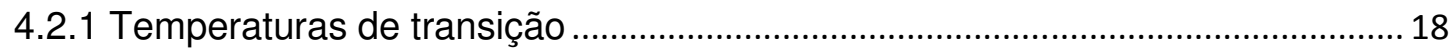

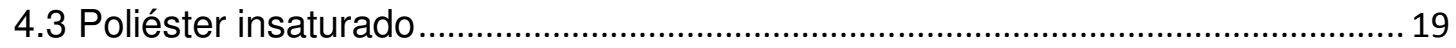

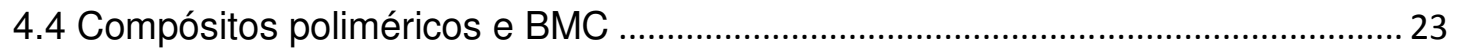

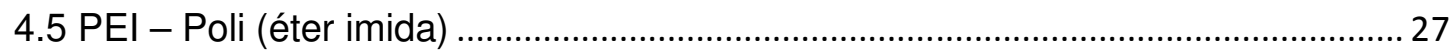

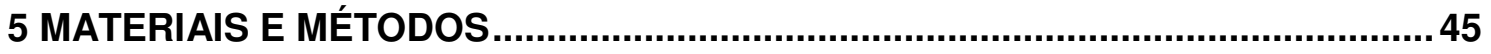

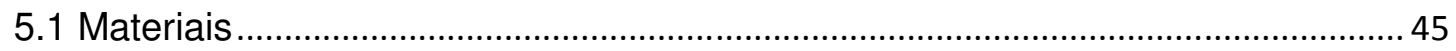

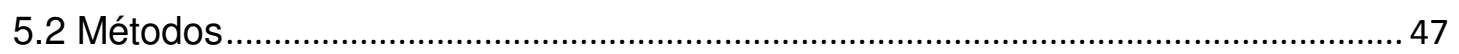

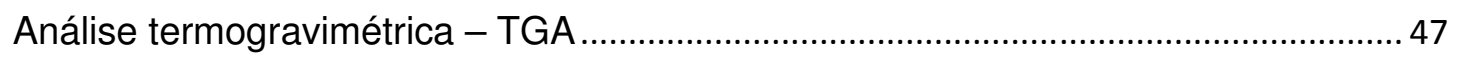

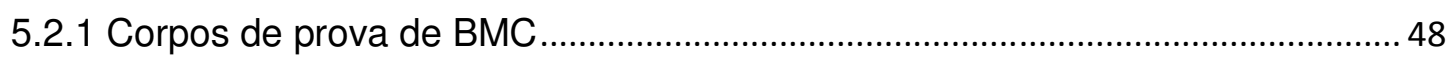

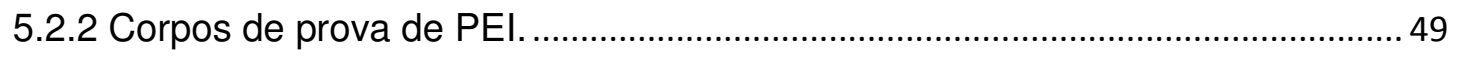

5.2.3 Processos de fabricação dos refletores de PEI e de BMC.................................. 51

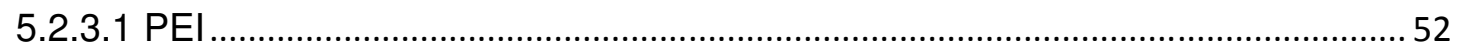

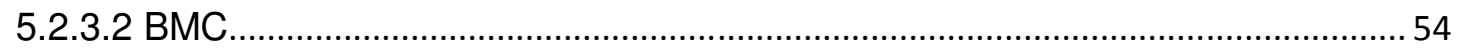

5.2.4 Determinação das frações volumétricas do compósito BMC ............................... 55

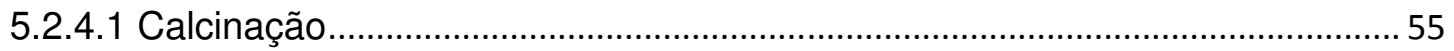

5.2.4.2 Análise quantitativa por espectrometria de fluorescência de raios X........... 56

5.2.5 Ensaio de resistência à tração .............................................................................. 56

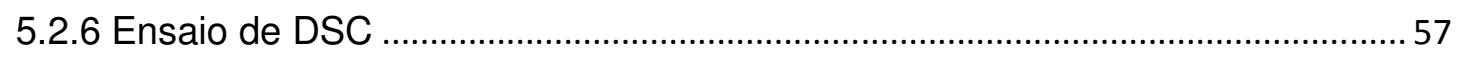

5.2.7 Ensaio de temperatura de amolecimento Vicat ...................................................... 57

5.2.8 Ensaio de temperatura de deflexão térmica - HDT ................................................. 58

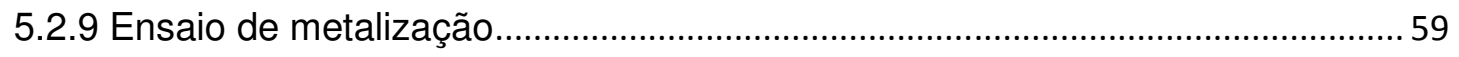

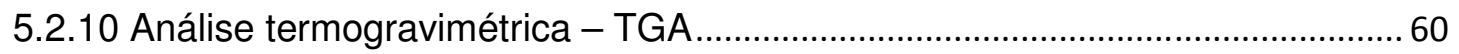

5.2.11 Reaproveitamento de resíduos de BMC.............................................................. 61 
5.2.12 Determinação da distribuição de tamanho de partícula dos resíduos de BMC moído. .65

5.2.13 Análise do BMC em pó via Infravermelho por transformada de Fourier (FTIR) .66

5.2.14 Incorporação do pó de BMC ao PVC e avaliação de propriedades. .67

5.2.14.1 Determinação da resistência à tração do composto de PVC com diferentes teores de BMC.

5.2.14.2 Determinação da resistência ao impacto do composto de PVC com diferentes teores de BMC.

5.2.14.3 Determinação da temperatura de amolecimento Vicat do composto de PVC com diferentes teores de BMC.

5.2.14.4 Determinação dos pontos de gelificação, fusão e degradação térmica do composto de PVC com diferentes teores de BMC

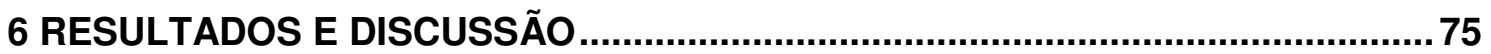

6.1 Ensaio de resistência à tração................................................................................. 75

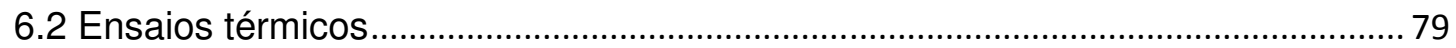

6.2.1 Determinação da temperatura de deflexão térmica (HDT) ……............................ 79

6.2.2 Determinação da temperatura de amolecimento Vicat do BMC ........................... 80

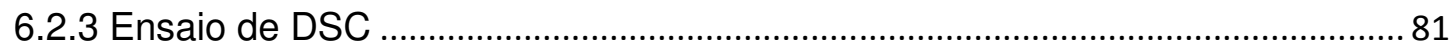

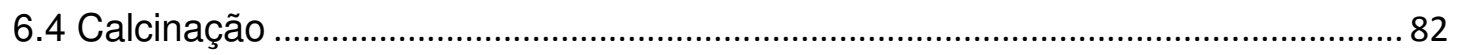

6.4 Análise quantitativa por espectrometria de fluorescência de raios X.................... 83

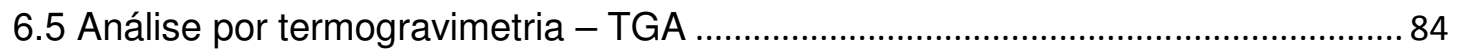

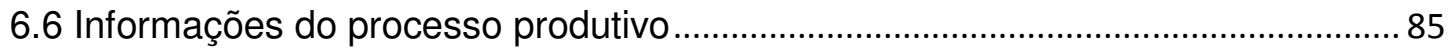

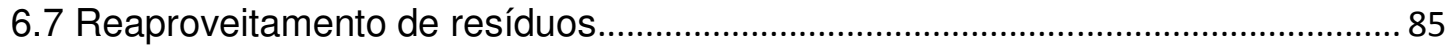

6.7.1 Análise granulométrica dos resíduos de BMC moído........................................... 87

6.7.2 Análise do BMC em pó via Infravermelho por transformada de Fourier (FTIR)88

6.7.3 O uso do resíduo de BMC nas formulações de PVC rígido .................................. 90

6.7.3.1 Resistência à tração dos compostos de $\mathrm{PVC}$ com $\mathrm{CaCO}_{3}$ e $\mathrm{BMC}^{2}$.................. 91

6.7.3.2 Resistência ao impacto dos compostos de $\mathrm{PVC}$ com $\mathrm{CaCO}_{3}$ e $\mathrm{BMC}$.............. 94

6.7.3.3 Determinação da temperatura de amolecimento Vicat do composto de PVC

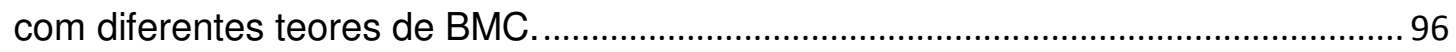

6.7.3.4 Determinação das condições de gelificação do composto de PVC com

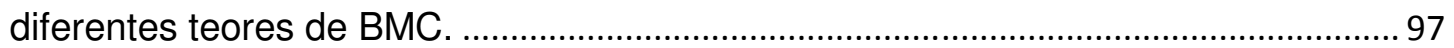

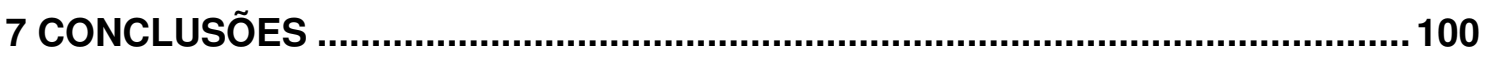

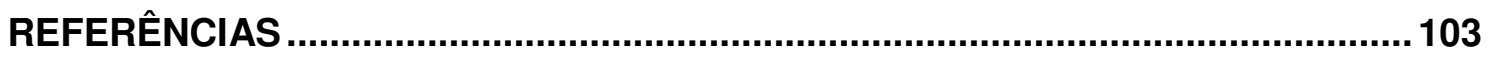

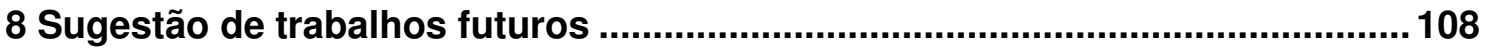




\section{INTRODUÇÃO}

O automóvel só atingiu a atual condição graças às constantes pesquisas realizadas no sentido de melhorar seu desempenho, considerando não só o tipo de combustível, mas também os materiais mais adequados à sua construção, tornando-o mais leve, mais resistente e mais durável.

Um componente que representa a evolução do automóvel é o farol. Os faróis localizam-se na parte frontal e têm a função de iluminar a via percorrida nos períodos de baixa visibilidade, como em momentos noturnos ou mesmo em dias nublados. Além disso, o veículo também precisa ser visível quando em movimento para proporcionar segurança aos usuários da via.

Os primeiros faróis, Figura 1.1 [Arteb, 2004], eram feitos de metal e como fonte de luz queimavam vela. O uso da vela era satisfatório para esse tipo de veículo pelo fato de o mesmo não alcançar velocidades superiores a $15 \mathrm{~km} / \mathrm{h}$.
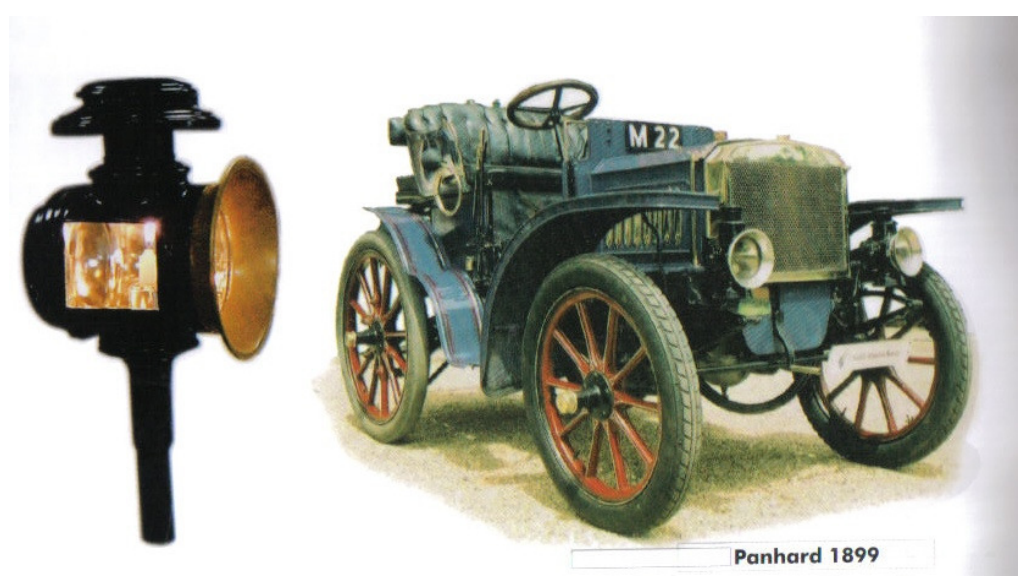

Figura 1.1 - llustração de um veículo que utilizava queima ou vela como fonte de luz [Arteb, 2004].

O uso da vela foi substituído pelo querosene ou óleo, principalmente pelo fato do automóvel alcançar maiores velocidades, que foram muito comuns nos primeiros automóveis do início do século XX e permaneceram nessa condição até serem substituídas pelo gás acetileno, baseado no uso das lanternas dos mineiros. $\mathrm{O}$ acetileno era usado porque resistia ao vento e a 
chuva e essa adaptação aos automóveis, embora tenha sido satisfatória, durou aproximadamente dez anos, período em que a concentração e multiplicação da luz usando refletores alcançaram significativos avanços.

A eficiência desse tipo de farol queimando acetileno ou óleo era muito limitada, porém permitia alguma melhora na iluminação da via para facilitar a movimentação do automóvel. Outro inconveniente nesse tipo de farol, ilustrado na Figura 1.2 [Arteb, 2004], era a possibilidade de queima do refletor em função da pouca distância entre a chama e o ponto focal.

Os fabricantes e os condutores de veículos conviveram com esse problema até a descoberta da lâmpada elétrica incandescente para automóveis em 1905 e a inclusão da mesma nos faróis poucos anos mais tarde. O problema nesse caso era a curta durabilidade da lâmpada pelo fato dos filamentos "queimarem" com certa facilidade.
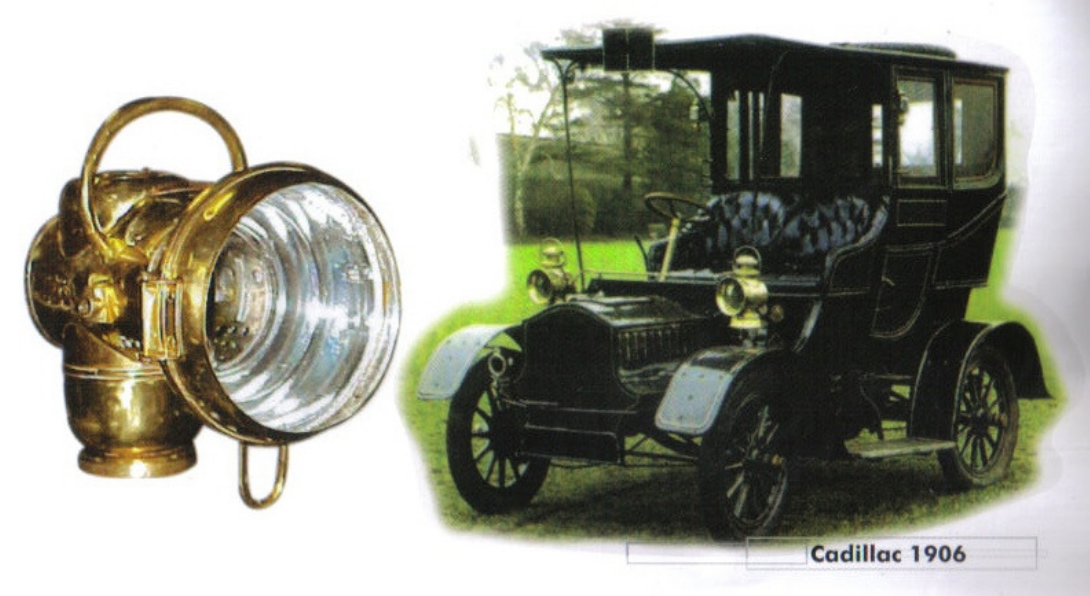

Figura 1.2 - Exemplo de veículo utilizando lanterna de acetileno [Arteb, 2004].

Nessa etapa do desenvolvimento dos faróis, foi notada a importância dos refletores, que eram estampados, prateados e polidos para aumentar 0 poder de reflexão. Essas iniciativas realmente melhoraram o desempenho dos faróis, tanto que o aumento da luz comprometia a visão dos veículos que trafegavam em sentido contrário, o que motivou as primeiras regulamentações resultando mais tarde no uso de faróis com uso de lâmpadas de dois filamentos, que permitia o ajuste do uso do farol. 
Um passo importante ocorreu na década de 20, onde foi feito o isolamento da parte interna e externa, ou seja, os faróis passaram a ser selados. $O$ fato de a lâmpada estar isolada do meio externo possibilitou maior durabilidade da mesma e eficácia do farol. A Figura 1.3 [Arteb, 2004] ilustra esse tipo de farol.
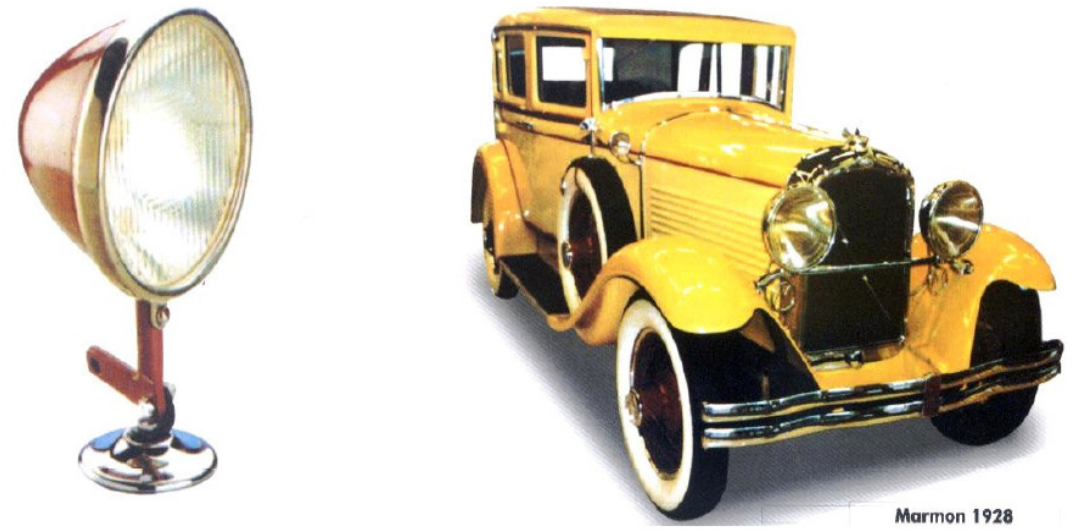

Figura 1.3 - llustração de um veículo utilizando farol selado [Arteb, 2004].

Esses faróis eram construídos de modo que uma grande lâmpada de vidro projeta o feixe de luz para um refletor parabólico metálico espelhado por uma camada de alumínio brilhante. A importância de o farol ser selado era dada de ele conter um gás inerte.

Um farol automobilístico atual é constituído por peças confeccionadas com diferentes materiais e essas peças possuem funções distintas. Todas as peças constituintes são importantes, mas a lâmpada e o refletor se destacam, pois são imprescindíveis para o funcionamento do farol. A própria história do desenvolvimento do automóvel, associada a seus componentes, é acompanhada pelo desenvolvimento dos materiais. No caso dos faróis, uma etapa marcante foi a substituição dos refletores metálicos por poliméricos.

Nos anos 60 a maioria dos faróis automobilísticos era confeccionada usando refletores metálicos, mas esses eram limitados em termos de reflexão da luz e as lentes precisavam corrigir as falhas oriundas da reflexão e direcionar da melhor maneira possível o feixe de luz, sem considerar ainda as 
dificuldades em relativas à estética do farol. A crise do petróleo ocorrida em 1973 foi um fator marcante para a melhoria na aerodinâmica dos veículos, pois, como já era de conhecimento, a redução do coeficiente de arraste proporcionava uma considerável economia de combustível.

A transição da produção de refletores metálicos para refletores poliméricos não foi uma tarefa muito fácil, mesmo porque as modificações das lentes como fator de correção das deficiências dos feixes refletidos eram caras. Essas deficiências ocorriam porque a produção envolvia sucessivas conformações por prensas e a reprodutibilidade desse processo não era constante.

Em 1971 a empresa Lucas Electrical Company apresentou o BMC, um composto para moldagem na forma de massa especificamente desenvolvido para uma nova geração de refletores. A importância desse novo produto foi muito grande porque eliminava as deficiências dos refletores metálicos além de proporcionar aos projetistas uma liberdade muito maior de forma, possibilitando a obtenção de geometrias mais complexas e funcionais além de permitir o desenvolvimento de novos produtos.

Os refletores atuais são projetados com uso do computador, de modo que cada ponto da superfície pode refletir a luz numa direção definida e isso permite uma grande eficiência do uso da luz gerada pela lâmpada, possibilitando faróis menores e mais eficazes.

A substituição do metal pelo polímero representou um importante passo na funcionalidade do farol uma vez que esse material tem moldabilidade muito maior. A Figura 1.4 [Monk, 1985] ilustra o quanto foi significativa essa transição da produção de refletores metálicos para refletores plásticos. Como toda transição, há um intervalo para que a mudança ocorra e durante muito tempo ainda se utilizou refletores metálicos. Esse uso foi cada vez mais reduzido e hoje em dia existem empresas que produzem refletores metálicos como peças de reposição para automóveis mais antigos.

As lanternas dos atuais automóveis são produzidas com materiais poliméricos como, por exemplo, a blenda de policarbonato - PC com poli(acrilonitrila butadieno estireno) - ABS, e são muito importantes na sinalização do automóvel, porém essa parte do veículo não foi considerada no presente estudo, por se tratar de um material de menor solicitação térmica. 


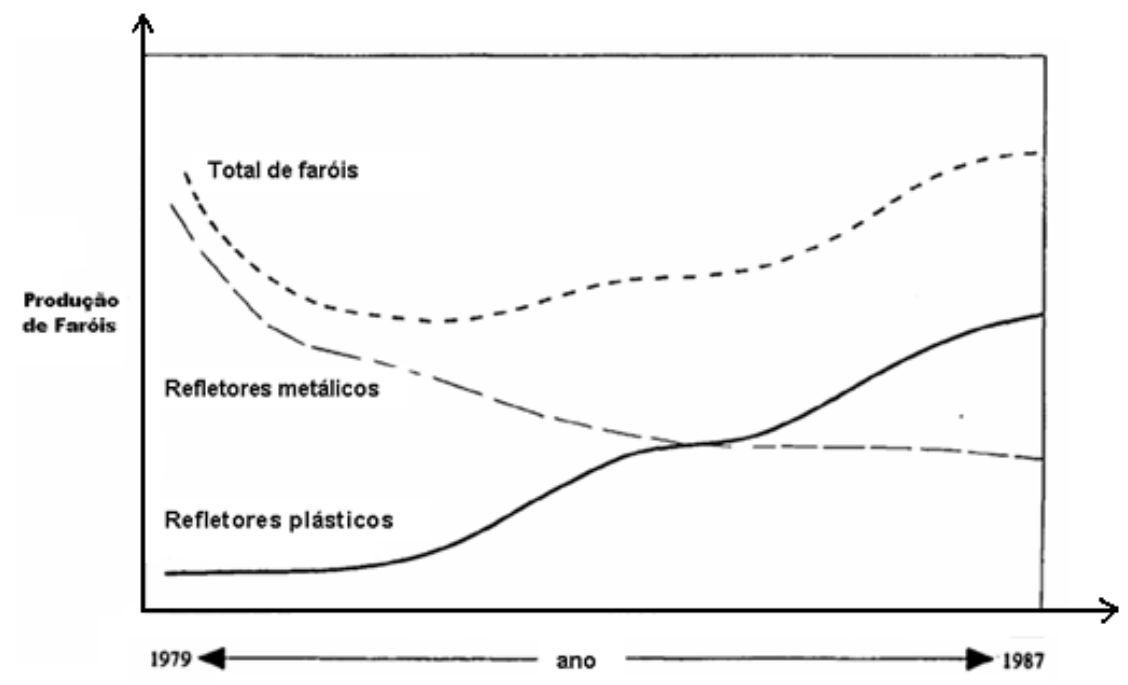

Figura 1.4 - Transição dos refletores metálicos para refletores plásticos [Monk,1985].

$\mathrm{O}$ uso do $\mathrm{BMC}$ em refletores contribui bastante para o aperfeiçoamento desse componente, contudo uma das dificuldades encontradas pelas empresas foi justamente a limitação térmica dos polímeros. $O$ fato desse material ser preparado a partir de formulações com diferentes teores de poliéster insaturado, carbonato de cálcio e reforços de fibra de vidro, possibilitou o desenvolvimento de formulações que se mantinham estáveis depois de longos períodos expostas a temperaturas de $200^{\circ} \mathrm{C}$.

A Figura 1.5 [Arteb, 2004] mostra um exemplo de farol cujo refletor é confeccionado com BMC, material polimérico termofixo, que favorece não só a funcionalidade do farol, como também o aspecto estético e também a produtividade.

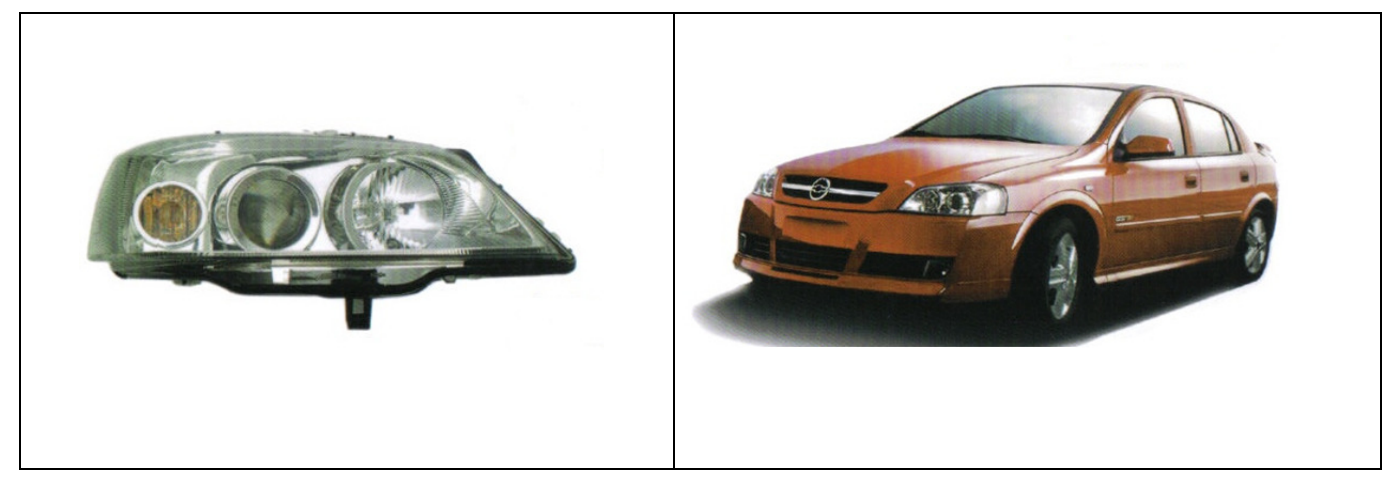

Figura 1.5 - llustração de veículo utilizando refletor produzido com BMC [Arteb, 2004]. 
O PEI - poli (éter imida) é um exemplo de polímero termoplástico utilizado na confecção de refletores automobilísticos e esse foi uma opção de algumas montadoras para alguns de seus veículos tais como Ford, Toyota, Daihatsu, BMW, Mercedes, Volvo, Volkswagem, Peugeot e Renault conforme a Figura 1.6 [Sabic,2009].

Os avanços alcançados no desenvolvimento na produção do automóvel o tornaram bastante favorável à vida moderna, sendo esse em muitos casos um símbolo de estilo de vida. Porém, com essas condições favoráveis, vieram também as preocupações ambientais, pois na confecção de um automóvel são utilizados metais, vidros e polímeros e o fator reciclagem acaba sendo uma questão de muita relevância. Somente nos Estados Unidos, 15 milhões de veículos chegam ao final de sua vida útil e mais de $75 \%$ deles são reciclados, sendo que mais de 5 milhões de toneladas de resíduos provenientes do setor automobilístico são moídas e destinadas aos aterros sanitários.

No Brasil, em 2006 foram produzidos mais de dois milhões de veículos e um automóvel moderno possui em torno de $150 \mathrm{~kg}$ de material plástico e apenas parte desse material é reciclado, daí a importância de se catalogar os materiais utilizados na fabricação de veículos para torná-los recicláveis e menos agressivos ao meio ambiente.

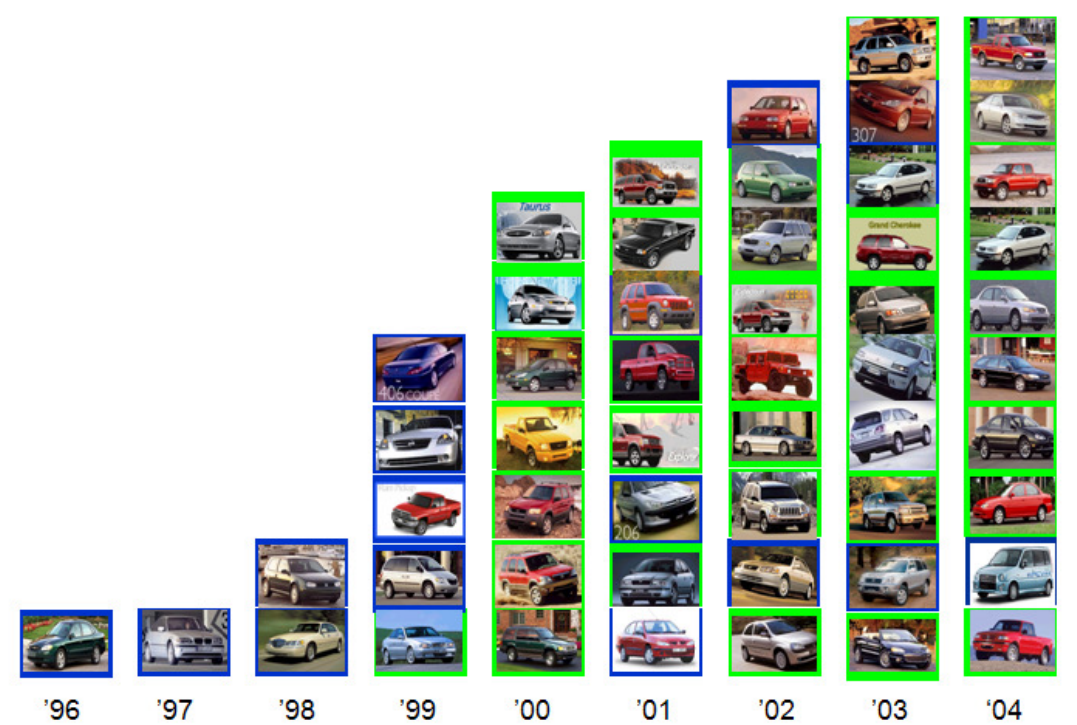

Figura 1.6 - Veículos que utilizam o PEI na confecção de refletores [Sabic, 2009] 


\section{OBJETIVO}

Este trabalho tem como proposta o estudo do BMC e do PEI, dois dos principais materiais poliméricos utilizados na indústria automobilística para confecção de refletores para faróis. O estudo é feito a partir da avaliação das propriedades térmicas e mecânicas, da aderência da camada de metal de acordo com cada material. Visando a uma opção para o problema de reaproveitamento do material termofixo, foram realizados testes analisando a incorporação do BMC no PVC. 


\section{REVISÃO BIBLIOGRÁFICA}

3.1 Iluminação automotiva

A iluminação automotiva é um sistema de grande importância num automóvel que apresenta as funções de sinalizar a parte traseira, frontal e laterais do veículo. A finalidade desse sistema é proporcionar segurança, indicando a presença, posição, tamanho, direção e intenções do condutor. No caso específico do farol automobilístico a principal função é iluminar a pista a ser percorrida pelo veículo para que o condutor tenha perfeita visão das condições de tráfego e perceba os possíveis obstáculos. Além de iluminar a pista, a iluminação de um veículo permite a sinalização de mudança de direção e informação de possíveis problemas de manutenção. Essas funções são desempenhadas pelos faróis e lanternas, os quais segundo os manuais de tecnologia automotiva incluem farol de luz baixa, farol de luz alta, farol de neblina, farol auxiliar de luz alta, luz intermitente (indicador de direção), lanterna de estacionamento, lanterna de contorno/delimitação (veículos largos), farol diurno (quando exigido por lei, em países específicos) [Bosch, 2000].

A grande maioria dos faróis automotivos atuais utiliza como fonte de luz as lâmpadas incandescentes, pois atendem às normas vigentes, além do que apresentam uma relação custo benefício bastante satisfatória. Outra fonte de luz já existente em alguns faróis é a lâmpada a descarga de gás que pode ser classificada como uma possível tecnologia substitutiva às lâmpadas incandescentes. Essa última tecnologia é usada em alguns automóveis produzidos no Japão, América do Norte e Europa e só não é muito utilizada atualmente pelo fato de ser composta de alguns componentes eletrônicos bastante caros.

Um encontro promovido pelo Centro de Referência Técnica Automotiva (CERTA) na cidade de São Paulo, em junho de 2009 reuniu profissionais da indústria automobilística, representantes de centros de reciclagem e entidades ligadas a elas para debater a reciclagem de veículos no Brasil, que atualmente possui legislação que regulamenta apenas a reciclagem de pneus e baterias. $O$ propósito principal do encontro foi estimular a formação de propostas de leis para disciplinar a atividade no país, a exemplo da Europa que possui uma diretiva que estabelece que até 2015 os materiais usados na confecção de um 
automóvel deverão ser reutilizados ou reciclados. Considerando a informação apresentada, é interessante que os materiais usados nas diversas partes que compõem um automóvel sejam conhecidos, inclusive as partes que apresentam mais de uma opção para sua composição, como é o caso dos refletores que podem ser confeccionados tanto em material termofixo quanto com material termoplástico.

Apesar do desenvolvimento alcançado nos automóveis as pesquisas não param, pois na concepção das empresas os resultados atuais ainda podem ser melhorados significativamente, principalmente com a crescente preocupação com os impactos ambientais causados tanto nas diversas etapas de produção quanto pelas influencias geradas na locomoção e o descarte ao final de sua vida útil. Um exemplo relacionado ao desenvolvimento dos faróis automotivos são as novas formas de gerar luz.

Atualmente a maioria dos faróis automotivos utiliza lâmpadas incandescentes, porém alguns protótipos já foram concebidos utilizando uma nova tecnologia baseada em diodos emissores de luz (LEDs). Esse tipo de tecnologia só tornou-se viável por conta do avanço na emissão de luz proporcionado por esses semicondutores. A grande vantagem dos LEDs está no fato destes gerarem uma luz branca com uma intensidade elevada e também terem maior durabilidade e menor custo de manutenção. Além das vantagens atribuídas os LEDs, esses ainda aquecem muito menos que as lâmpadas incandescentes o que possibilita aos projetistas criarem faróis de tamanho reduzido, que é uma tendência natural das formas geométricas dos automóveis modernos [Martins, 2005].

Numa possível redução dos custos, as lâmpadas LEDs representam a possibilidade de mudança não só do estilo do automóvel e forma de produzir luz automotiva como também a possibilidade de mudança nos materiais que integram o farol. Nesse caso a solicitação térmica não seria tão intensa e a o refletor poderia ser construído de um material menos resistente ao calor do que o BMC.

É fato que a mudança do material de construção dos refletores, que inicialmente eram de material metálico e passou para material polimérico, é um caminho irreversível pelas vantagens proporcionadas por esse último material. Portanto, os esforços se concentram em adequar o material polimérico aos 
desenvolvimentos almejados pelos fabricantes de veículos. Os refletores em sua maioria não só no Brasil, mas em todos os países que fabricam automóveis, são produzidos com compósito polimérico termofixo principalmente pela resistência térmica que o material oferece.

\subsection{Materiais termofixos e a indústria automobilística}

Numa pesquisa de mercado realizada em 2009 [Plástico Industrial, 2009], foi traçado o perfil das empresas que moldam compósitos termofixos e algumas informações ligadas ao setor automobilístico. Segundo a publicação, a produção de compósitos no Brasil foi dividida nas seguintes proporções: construção civil $18 \%$, químico e petroquímico 10,95\%, máquinas e equipamentos com 10,95\%, automotivo $9,7 \%$, esporte e lazer $9 \%$, açúcar e álcool $8,2 \%$, elétrico $7,55 \%$, náutico $6,15 \%$, eletroeletrônicos $3,40 \%$, eletrodomésticos $2,75 \%$, aeronáutico/aeroespacial $1,35 \%$ e outros $12 \%$.

Apesar da quantidade de compósito polimérico termofixo processado no Brasil destinado ao mercado automobilístico não ser um número tão expressivo, o segmento automotivo está entre os mais representativos em termos de faturamento das empresas transformadoras. O reaproveitamento das sobras de processo é feito por apenas $34,2 \%$ das empresas, o que é muito relevante em termos de comprometimento com o meio ambiente com a deposição de material em aterros. A pesquisa apontou ainda que o volume de material termofixo tenha aumentado, trazendo maior preocupação com relação às questões ambientais.

A Figura 3.1 [Mazumdar, 2002] ilustra o consumo de compósitos no mercado americano no ano de 1999 e a projeção para o ano 2000. O gráfico permite a visualização dos segmentos que utilizam compósitos e qual o volume de consumo de cada um deles. É possível identificar que o segmento de maior consumo é justamente $o$ de transporte, que abrange também o mercado automobilístico. 


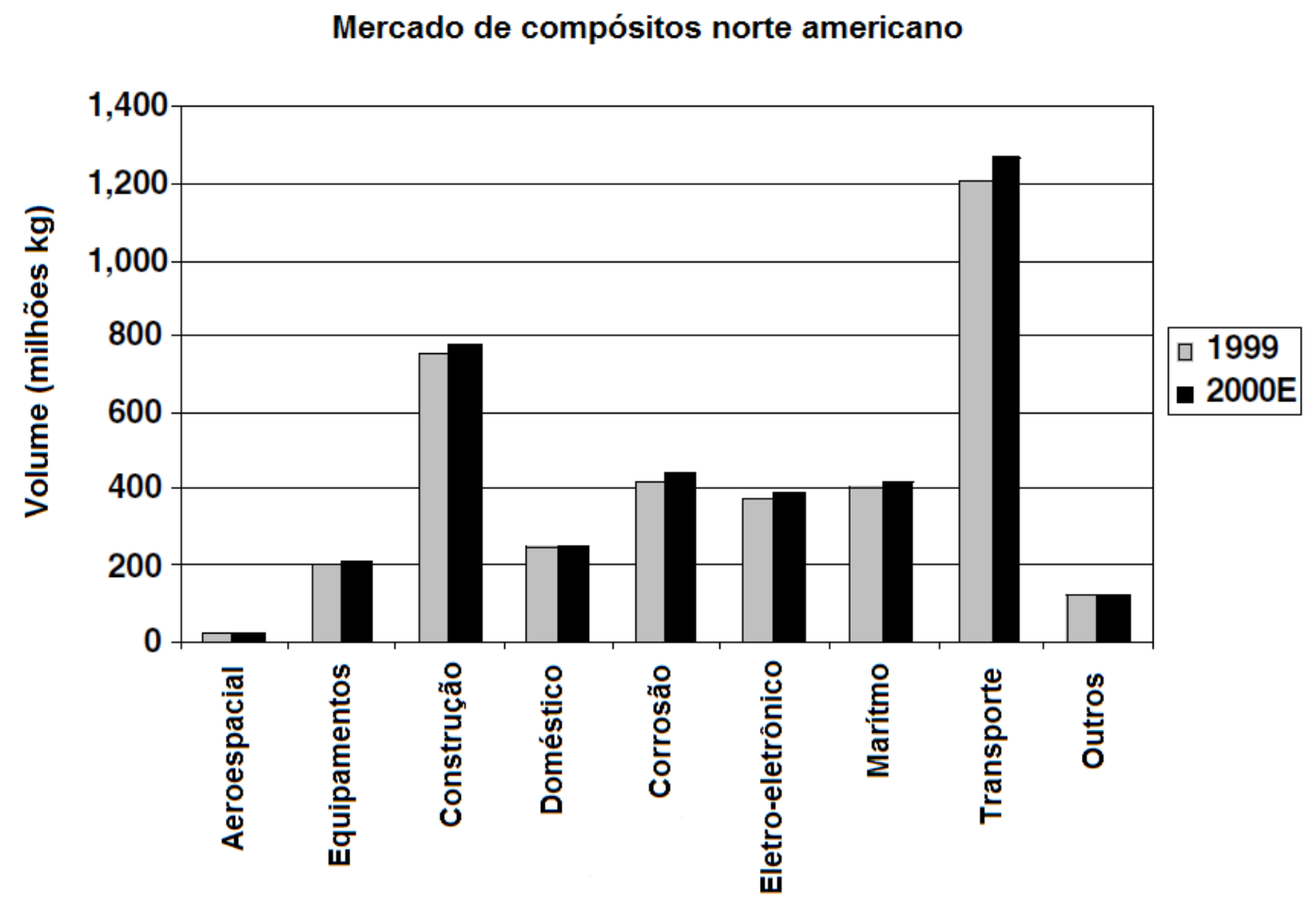

Tipo de Indústria

Figura 3.1 - Volume de compósitos em vários segmentos industriais no ano de 1999 e a projeção para 2000 [Mazumdar, 2002]

Os compósitos poliméricos termofixos, em suas diversas aplicações, não apresentam restrições significativas com relação ao desempenho independente da solicitação. O grande problema está na questão ambiental com relação à reciclabilidade dos materiais usados na confecção do veículo. Os investimentos no sentido de tornar os veículos menos agressivos ao meio ambiente tem sido consideráveis em diferentes lugares do mundo, quer no desenvolvimento de energias limpas ou menos poluidoras, quer seja no uso de materiais mais leves, mais resistentes e que possam ser reciclados.

No mercado automobilístico brasileiro o uso de material termofixo tem grande potencial de crescimento, principalmente nos veículos de pequeno porte, haja vista que em veículos pesados tais como ônibus, caminhões, tratores e utilitários o uso é mais expressivo. A indústria automobilística corre contra o tempo, no sentido de usar em seus produtos matérias primas recicláveis e isso tem contribuído para as pesquisas e desenvolvimento de termoplásticos que possuam maior resistência térmica e melhores propriedades mecânicas. 


\section{ABORDAGEM TEÓRICA}

\subsection{O automóvel e os materiais}

A evolução dos sistemas tecnológicos automotivos pode ser dividida em três períodos: o primeiro caracterizado por automóveis grandes e potentes, inicia-se no começo da década de 60 e vai até meados da década posterior, quando aconteceu a crise mundial do petróleo. O segundo período é marcado pela solicitação dos consumidores de possuírem automóveis potentes, porém que fossem econômicos; esse período foi marcado pelo desenvolvimento de automóveis pequenos, o que possibilitou economia de aço e principalmente economia de combustível. O terceiro período inicia-se na década de 90, caracterizado pelo término da crise do petróleo e pela exigência dos consumidores de automóveis mais complexos e de maior porte que apresentassem melhor desempenho e fossem menos poluentes.

O desenvolvimento do automóvel é acompanhado pela evolução dos materiais pelo fato de torná-lo menos agressivo ao meio ambiente e mais confortável. A redução de massa proporcionada pelo uso de materiais leves nos veículos tem uma importante relação com a economia de combustível dos veículos e essa depende do tipo de veículo.

A redução de peso de um veículo automotor proporciona além da economia de energia, ganhos ambientais pelo fato de conservar melhor as estradas diminuindo as intervenções com manutenção tanto das vias de circulação quanto dos veículos, diminuição na liberação de $\mathrm{CO}_{2}$ amenizando o aquecimento global por conta de diminuir os fatores que contribuem para 0 efeito estufa.

O uso de materiais poliméricos num automóvel tem crescido e também os tipos de polímeros e os pontos onde esses materiais são aplicados também. A Figura 4.1 [Andrady, 2003] mostra a evolução e uso de materiais plásticos nos automóveis. O aumento de polímeros nesse segmento foi conseguido em função de uma série de fatores positivos tanto na área de materiais quanto na área de processos. Um desses fatores foi a Segunda Guerra Mundial que provocou uma busca bastante acirrada pelo desenvolvimento de novos 
materiais e produtos e muitos materiais oriundos dessas descobertas passaram a ser utilizados em veículos automotores.

O automóvel na condição de objeto técnico-mecânico se destaca justamente pela sua complexidade, pois reúne atualmente além do metal, pelo menos 50 tipos de materiais plásticos, vidros, produtos têxteis, tinta e outros mais. Esses materiais são associados por meio de diferentes tecnologias, processos de produção, tratamento e montagem. Não somente polímeros, mas outros materiais não ferrosos têm sido utilizados cada vez mais nos automóveis, ou seja, muitos desses materiais podem ser reciclados e isso tem uma influência bastante positiva no valor agregado dos produtos. Tanto que o volume de material reciclado sendo baixo tem apresentado taxas de crescimento e essa evolução é acompanhada diretamente pelos materiais usados nas diversas partes do automóvel.

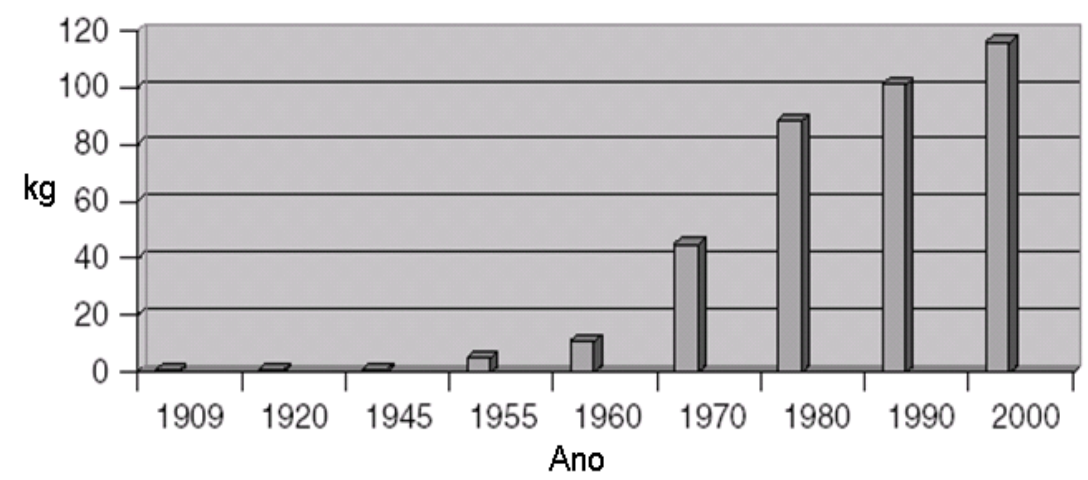

Figura 4.1 - Quantidade de material plástico em quilograma num veículo. [Andrady, 2003].

No sistema de iluminação externa de um veículo, mais especificamente num farol ou lanterna, são utilizados os seguintes materiais plásticos: nas lentes policarbonato (PC) ou poli (metacrilato de metila) (PMMA) mais conhecido como acrílico e nas carcaças blendas de acrilonitrila-butadienoestireno com policarbonato (ABS/PC) ou polipropileno com talco (PP) e nos refletores poli (éter imida) (PEI) ou composto em forma de massa para moldagem (BMC).

Existe entre os fabricantes de automóvel a preocupação da utilização de materiais que sejam menos agressivos ao meio ambiente e que sejam auto- 
sustentáveis, pois as pressões dos órgãos ambientais são cada vez maiores e é cada vez mais nítida a questão que a perenidade das empresas passará inicialmente pela responsabilidade com o meio ambiente.

\subsection{Polímeros}

Os polímeros são materiais macromoleculares formados por unidades químicas simples que se repetem. As macromoléculas poliméricas normalmente são compostas por hidrocarbonetos, porém podem conter em sua estrutura outros elementos químicos como, por exemplo, o oxigênio, nitrogênio, flúor ou o cloro.

A palavra polímero origina-se do grego onde o prefixo poli significa muito e o sufixo mero significa partes. Os polímeros são utilizados pela humanidade há muito tempo, porém na condição de polímeros naturais, uma vez que o primeiro polímero sintético foi descoberto na década de 1910. A vedação de vasilhames e selagem de documentos são exemplos de aplicações dos polímeros naturais na antiguidade. Mesmo na atualidade, os polímeros naturais são utilizados, como, por exemplo, a borracha natural e o celofane.

As substâncias capazes de dar origem aos polímeros são chamadas de monômeros, que dependendo da estrutura podem apresentar diferentes características e conseqüentemente diferentes mecanismos de reação. Um exemplo clássico para entender a transformação do monômero em polímero é a polimerização do etileno, ilustrado na Figura 4.2 que após a reação passa a ser denominado de polietileno. Esse polímero, apesar de apresentar a estrutura mais simples, é atualmente o que apresenta maior volume de produção no mundo.

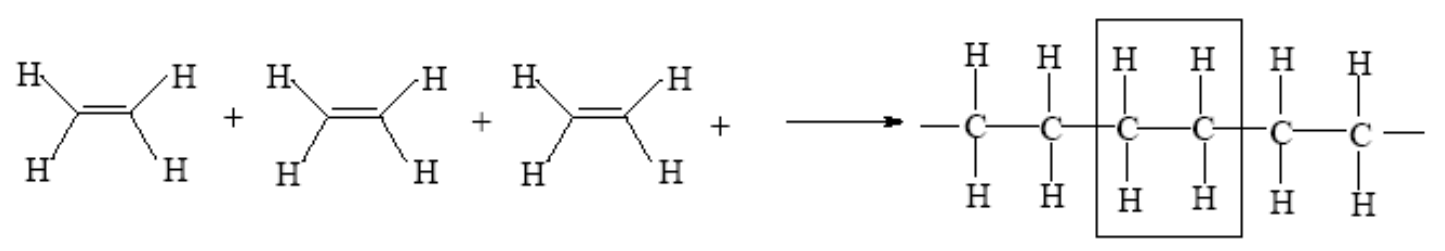

Monômero

Unidade repetitiva

Figura 4.2 - Reação de polimerização do etileno. 
A reação apresentada é chamada de polimerização e nessa reação acontece a síntese do polímero. À temperatura ambiente, o etileno na condição de reagente é um gás e o polietileno na condição de produto à temperatura ambiente é sólido.

As ligações químicas que se estabelecem entre os elementos que constituem as macromoléculas são covalentes e essas são formadas durante a reação de polimerização a partir de ligações existentes entre na estrutura dos monômeros. O controle dos parâmetros da reação de polimerização é muito importante porque terá influência direta sobre o tamanho das macromoléculas e sobre as propriedades do polímero. Dentre esses parâmetros os principais são temperatura, pressão, tempo e o tipo de reator.

Existem diferentes critérios para classificação dos polímeros. A Figura 4.3 mostra uma dessas classificações que permite visualizar alguns critérios de classificação de materiais poliméricos.

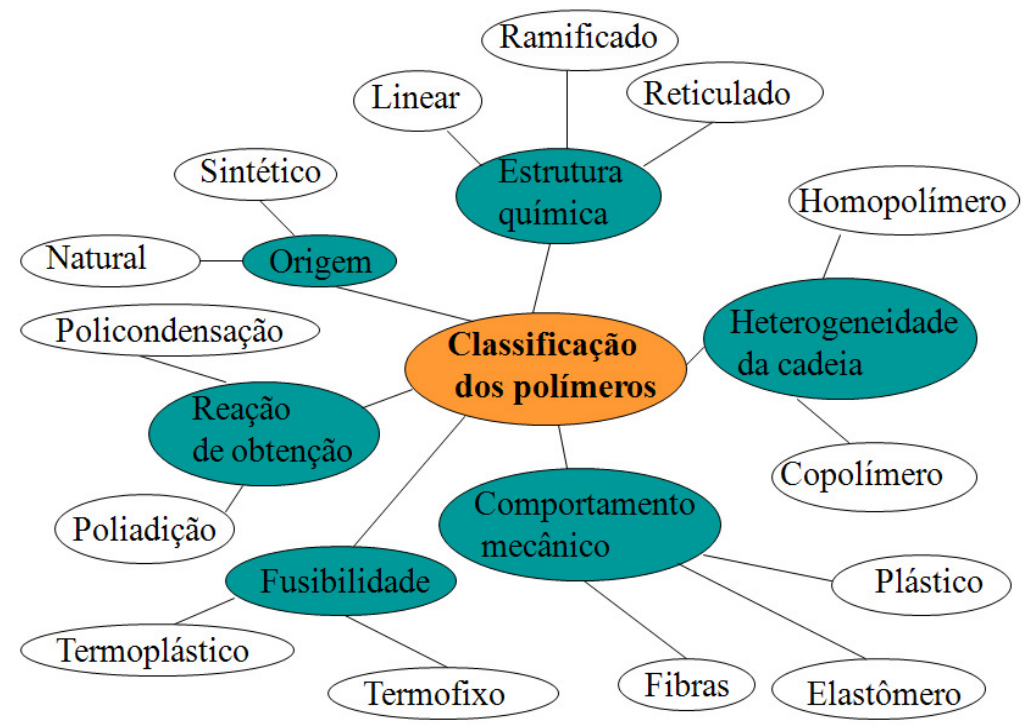

Figura 4.3 - Classificação simplificada dos polímeros.

Os materiais poliméricos apresentam temperaturas de transição de acordo com suas estruturas e essas são de muita importância para 0 entendimento das propriedades térmicas, mecânicas e físicas. Não há como referir-se a essas temperaturas sem citar as regiões presentes nas estruturas poliméricas. Essas estruturas podem ser amorfas ou semi-cristalinas.

Uma estrutura polimérica será amorfa quando as diversas macromoléculas apresentarem-se totalmente desorganizadas, ou seja, quando 
não existir eqüidistância entre essas macromoléculas por um período que caracterize um cristal. O fato dos polímeros serem constituídos essencialmente de moléculas grandes impossibilita a formação de uma estrutura totalmente cristalina. Portanto por mais organizado que seja um polímero sempre haverá regiões desorganizadas.

\subsubsection{Temperaturas de transição}

Os polímeros sendo materiais constituídos por macromoléculas formadas essencialmente de elementos químicos não metais que apresentam propriedades muito distintas quando comparado com os metais e as cerâmicas. Uma dessas propriedades são as temperaturas de transição que servem para explicar uma série de comportamentos dos materiais poliméricos. Por meio das temperaturas de transição é possível entender porque à temperatura ambiente alguns polímeros são rígidos e outros são macios e elásticos.

Existem basicamente três tipos de temperaturas de transição, descritas a seguir:

- Temperatura de transição vítrea $(\mathrm{Tg})$ é a temperatura acima da qual as macromoléculas poliméricas da fase amorfa adquirem mobilidade; abaixo dessa temperatura os polímeros apresentam-se rígidos, ou seja, não há mobilidade entre as moléculas porque as mesmas ficam "congeladas".

- Temperatura de fusão cristalina $(T m)$ é a temperatura onde as macromoléculas da fase cristalina começam a se movimentar em função do aumento da solicitação térmica e os cristais deixam de existir.

- Temperatura de cristalização (Tc) é a temperatura onde os cristais se formam por conseqüência do resfriamento do polímero. 


\subsection{Poliéster insaturado}

O poliéster insaturado é material polimérico termofixo que possui ligações cruzadas entre diferentes moléculas após a cura. $\mathrm{O}$ cientista $\mathrm{H}$. Staudinger foi primeiro a investigar o mecanismo de ligações cruzadas das resinas de poliéster insaturado em 1934, porém a primeira patente da polimerização do poliéster insaturado em moldes só foi recebida em 1936.

Os poliésteres foram historicamente os primeiros polímeros de condensação estudados nos trabalhos pioneiros de Carothers em 1930, materiais que mais tarde foram produzidos comercialmente. As resinas de poliéster insaturado são mais comumente conhecidas como resinas poliéster, mas pelo fato de serem materiais processados in situ podem ser chamados de resinas reativas.

É importante ressaltar que existem outros tipos de poliéster na família dos polímeros, porém esses outros exemplos são de materiais termoplásticos, como é o caso do PET poli (etileno tereftalato), material oriundo do ácido tereftálico e do etileno glicol. As resinas de poliéster insaturado são as mais utilizadas nos compósitos poliméricos termofixos e apresentam a vantagem de poderem ter diferentes formulações, adequando o material à aplicação.

As matérias primas principais para a produção do poliéster insaturado são ácidos carboxílicos saturados, ácidos carboxílicos insaturados, glicóis e monômeros. Dentre essas matérias primas, estão o ácido fumárico, anidrido maleico, ácido isoftálico, propileno glicol, etileno glicol e o estireno. Cada um dos componentes da resina de poliéster insaturado tem uma finalidade específica.

A reação principal para a obtenção do poliéster insaturado é uma reação de esterificação onde um ácido carboxílico reage com um glicol formando grupos ésteres. Esse tipo de reação, segundo a classificação de Carothers é uma reação de condensação que pode ser entre monômeros bi ou poli funcionais que acontecem com a eliminação de moléculas pequenas. A quantidade de insaturações dependerá do teor de ácido insaturado. Esse fator é relevante, pois as propriedades do poliéster insaturado dependem dentre outros fatores da quantidade de insaturações presentes nas cadeias poliméricas. 
O poliéster insaturado é um polímero de relativamente baixo grau de polimerização, com peso molecular entre 1500 e 3000 unidades de massa atômica. Para redução da viscosidade do poliéster é utilizado um monômero, que atua como solvente, normalmente o estireno, em concentrações de 30 a $50 \%$. A necessidade de se incorporar o solvente pode ser justificada pela facilidade de movimentação das moléculas facilitando, portanto, a formação das ligações cruzadas e também por participar das ligações formadas após a polimerização. O teor de estireno não pode exceder um determinado limite porque pode haver formação de segmentos de moléculas de poliestireno, comprometendo as propriedades do poliéster. A Figura 4.4 [Chanda, 2006] apresenta uma reação típica para obtenção do poliéster insaturado. Quase todos os poliésteres insaturados comerciais têm solventes em suas composições e o estireno não é o único solvente adicionado ao poliéster insaturado. Outros exemplos de solventes comuns são os seguintes: vinil tolueno, dialil ftalato e metil metacrilato.

Para que a reação aconteça, ao poliéster deve ser adicionado um iniciador, normalmente peróxidos, que são substâncias altamente reativas e atuam como "catalisadores". Essas substâncias são responsáveis pela ruptura de uma das ligações covalentes das insaturações de moléculas isoladas e a conseqüente formação das ligações cruzadas entre diferentes moléculas. Nessa reação haverá também a interconexão de moléculas do poliéster com o estireno.

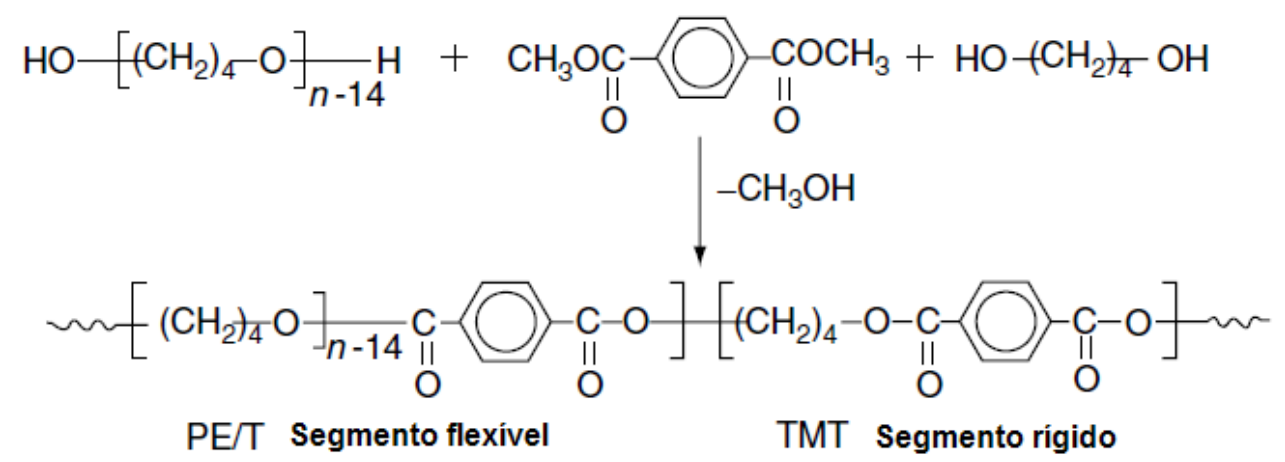

Figura 4.4 - Formação do poliéster insaturado ou copolímero em bloco [Chanda, 2006]. 
A Figura 4.5 [Chanda, 2006] exibe um modelo típico do poliéster insaturado antes da reação de polimerização onde é possível notar- se que as matérias primas formam uma mistura normalmente miscível, porém a reação ainda não aconteceu porque não ocorreu ligação entre os diferentes componentes da mistura. Nessa condição, o estado físico da mistura estará com aspecto de um líquido viscoso, ou até mesmo pastoso, o que depende do tipo de processamento a que esse material será submetido. Se for, por exemplo, resinas de poliéster para laminação é importante que a viscosidade seja relativamente baixa.

Um fator importante que deve ser considerado é que as reações do poliéster insaturado quando misturado aos iniciadores e aceleradores são exotérmicas e isso envolve certos cuidados no manuseio do material, principalmente se os iniciadores forem para a chamada cura a frio. Se a quantidade de material for muito grande haverá proporcionalmente um aumento na energia liberada e isso compromete as propriedades do material, gerando problemas como trincas e conseqüentemente prejuízo nas propriedades mecânicas e térmicas. Uma forma de se diminuir esses efeitos é adição de cargas à resina, que são substâncias de enchimento com o objetivo principal de aumentar o volume do material, mas que tem a capacidade de dissipar a energia térmica desprendida da reação. Quanto melhor o controle da exotermia da reação, melhores serão as propriedades apresentadas pelo poliéster insaturado.

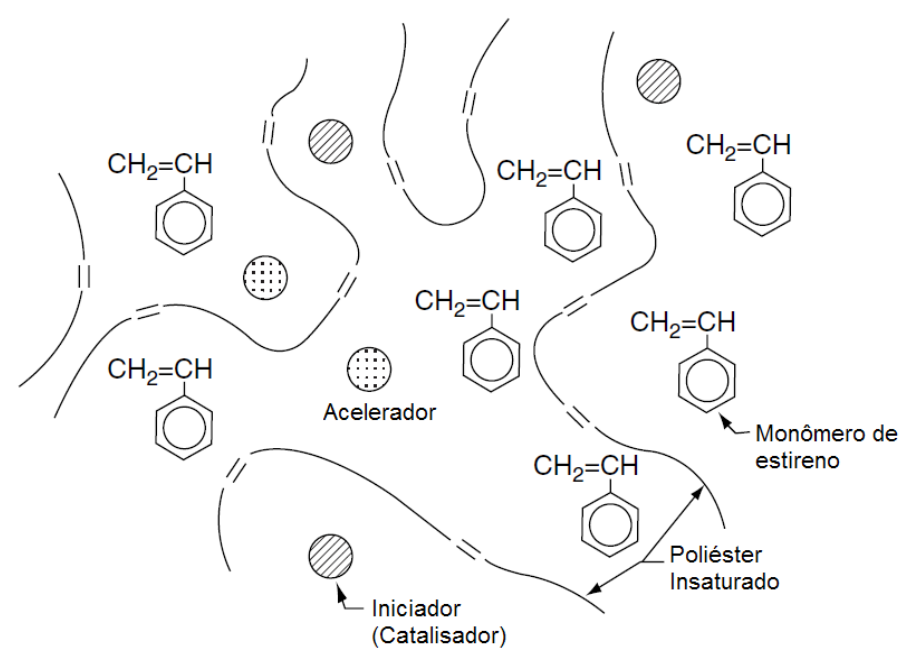

Figura 4.5 - Resina de poliéster antes da reação [Chanda, 2006]. 
Após a reação, mudará o estado físico da resina e também as propriedades, em função da formação de novas ligações. A Figura 4.6 [Chanda, 2006] exibe um modelo de estrutura presente num poliéster após a cura.

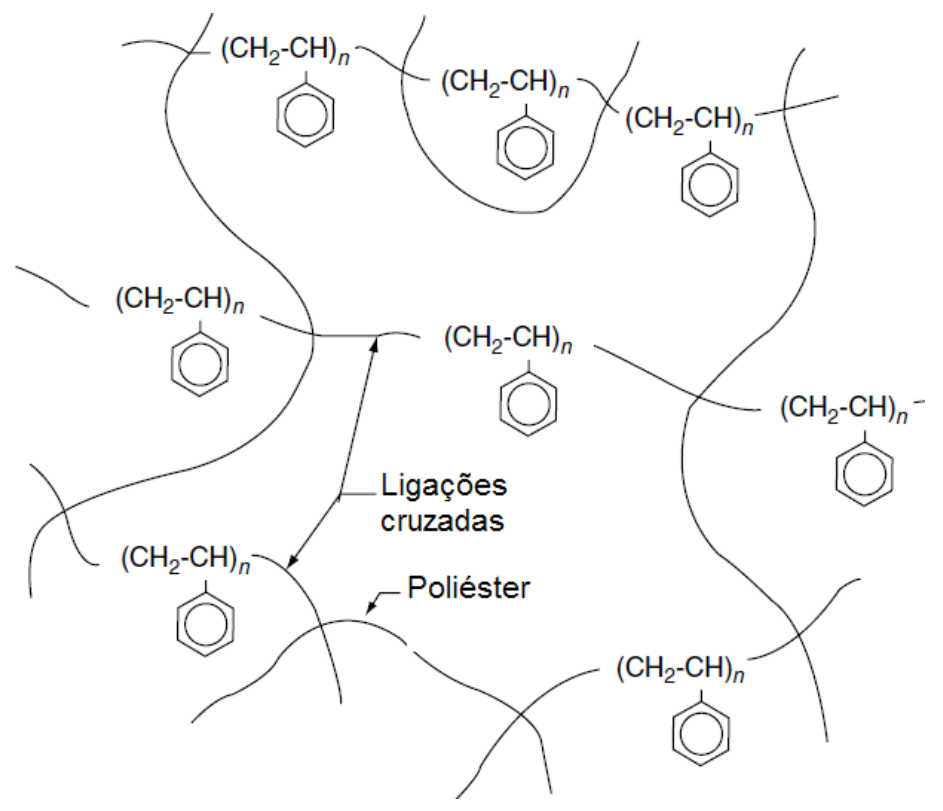

Figura 4.6 - Poliéster insaturado após a reação, o n do estireno está normalmente entre 2 e 3 [Chanda, 2006].

Para que o poliéster insaturado possa ser formulado e processado existem componentes, com finalidades específicas. Dentre esses, os mais usuais e suas respectivas funções são:

- Inibidores - Numa resina de poliéster insaturado é muito comum a formação de radicais livres formados espontaneamente pela luz solar, aquecimento ou substâncias contaminantes. Os radicais formados serão responsáveis pela formação das ligações cruzadas (crosslinking) no material prejudicando a qualidade da resina, pois o ideal, é que a cura ocorra somente quando for adicionado o iniciador. Para evitar esse problema, são adicionados ao material substâncias que reagem com os radicais livres formados, evitando uma reação prematura do material [Strong,1996]. Os inibidores podem ter o efeito retardante, que perde essa ação apenas quando é adicionado o iniciador à resina ou função estabilizante, que eliminará os radicais livres apenas abaixo de certas temperaturas. Essa característica do material justifica o fato do BMC que é um compósito de poliéster insaturado com fibras de vidro e outras 
substâncias em algumas situações serem armazenados em temperaturas entre 5 e $10{ }^{\circ} \mathrm{C}$.

- Aceleradores - O poliéster insaturado tem inúmeras aplicações e em algumas situações há necessidade da reação acontecer com maior velocidade como, por exemplo, nos casos de moldagem por injeção. Nesses casos, são adicionados ao material, substâncias que têm a propriedade de aumentar significativamente a velocidade de reação. Essas substâncias chamadas de aceleradores ou promotores de cura são baseadas em sais de metais como o cobalto, manganês, cobre ou aminas terciárias.

Os aceleradores têm a função de ativar os iniciadores, porém não podem ser misturados sem a resina porque a reação de baixíssima energia de ativação é muita violenta podendo ocorrer até mesmo princípio de incêndio

\subsection{Compósitos poliméricos e BMC}

O poliéster insaturado puro tem propriedades limitadas para uma série de aplicações, principalmente quando as solicitações são mecânicas. Para incremento das propriedades, o poliéster é usado na forma de compósito.

Um compósito polimérico é formado por duas fases principais: o componente matricial é a fase polimérica e o componente estrutural é a fase formada por um reforço, como por exemplo, a fibra conforme ilustrado na Figura 4.7.

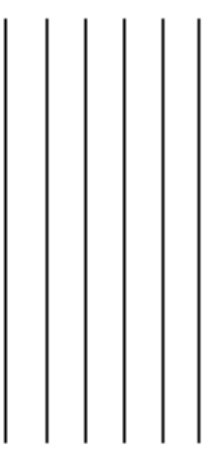

Fibras

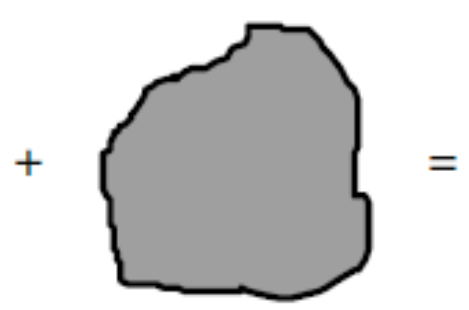

Resina

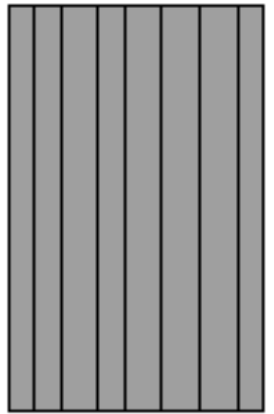

Compósito

Figura 4.7 - Formação de um compósito usando resina e fibras [Mazumdar, 2002]. 
A proporção entre o componente matricial e o componente estrutural determina as propriedades dos compósitos, daí a importância de se medir o teor de fibra de vidro presente num compósito. A fibra de vidro é o componente estrutural mais comum e de menor custo, mas existem outros tipos como, por exemplo, a fibra de carbono e a fibra aramida. Num compósito estrutural, o elemento de reforço (fibra) garante resistência mecânica e pode chegar a frações volumétricas de $70 \%$. Alguns compósitos podem ser isolantes elétricos, mas dependendo do tipo de fibra esse poderá ser condutor elétrico, sem nenhuma finalidade de competir com os metais. Dependendo do compósito as fibras podem ser curtas ou continuas, conforme ilustrado na Figura 4.8.

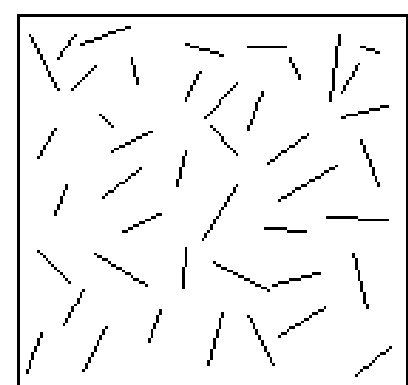

Compósito com fibras curtas

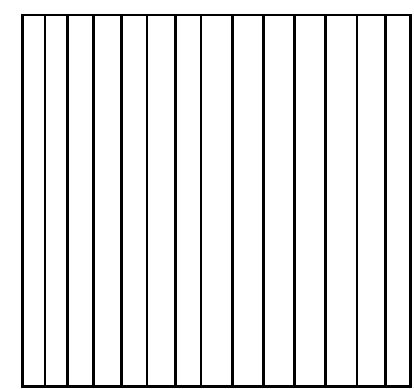

Compósito com fibras continuas

Figura 4.8 - Compósito usando resina com fibras curtas e resina com fibras longas.

Os compósitos poliméricos termofixos e termoplásticos em geral podem ser transformados em produtos por meio de diferentes processos de transformação, sendo os principais citados na Figura 4.9 [Mazumdar, 2002]. 


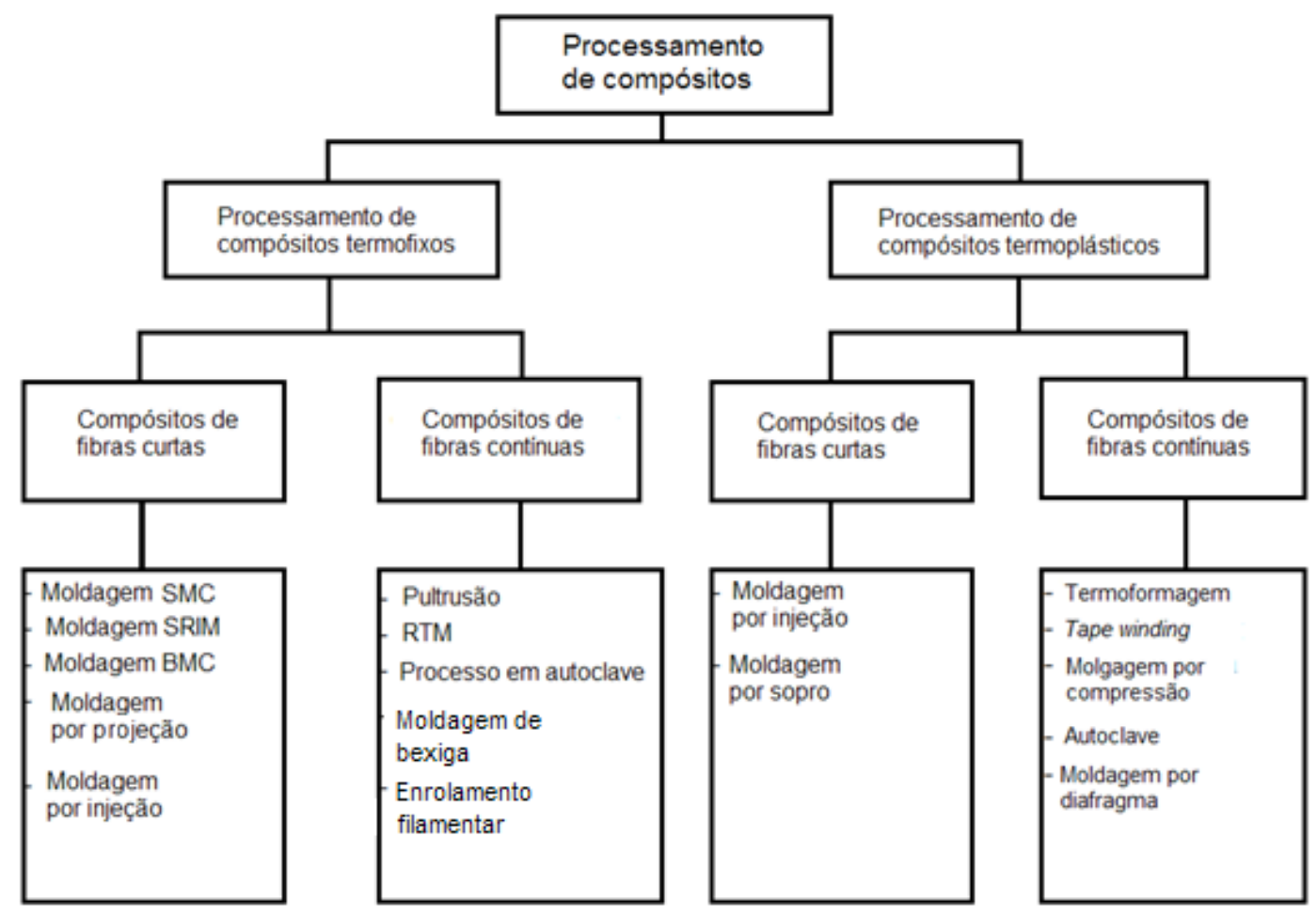

Figura 4.9 - Classificação das técnicas de processamento de compósitos [Mazumdar, 2002].

Nos compósitos, a resistência também depende da interação entre esses dois componentes. O componente matricial recebe o esforço e o transfere para o elemento estrutural por meio da interface, o que resulta numa condição importante para a integridade estrutural do material. O componente estrutural mais comum no caso dos compósitos poliméricos é a fibra de vidro, tanto que é comum encontrar a expressão "fabricado de fibra", fazendo referência a um compósito que consiste de fibras de vidro. Há também as fibras naturais que estão sendo gradativamente testadas e introduzidas na fabricação de compósitos, como por exemplo, as fibras de curauá, juta e cisal.

Para a produção do compósito de BMC existe a necessidade de se determinar o teor de cada componente da formulação, pois é possível se variar significativamente os teores e tipos de matérias primas usados na produção desses compósitos, quer seja na quantidade quer seja no tipo e tamanho das fibras de vidro utilizadas. Uma grande vantagem desse tipo de material vem do fato de se conseguir diferentes propriedades e atender as mais diversas 
solicitações. A Tabela 4.1 [KIA, 1993] apresenta uma possível formulação de $\mathrm{BMC}$.

Tabela 4.1 - Formulação típica de BMC [KIA, 1993].

\begin{tabular}{lc}
\hline & Formulação de BMC \\
\hline Pasta & \\
Componente da formulação & Teores (partes por cem de resina - PCR) \\
\hline Resina poliéster & 50 a 100 \\
Aditivo termoplástico & 0 a 50 \\
Monômero de estireno & 0 a 5 \\
Catalisador & 0 a 2 \\
Cargas & 50 a 300 \\
Pigmento & 0 a $\ldots .$. \\
Composto & 10 a $25 \%$ \\
Pasta & 75 a $90 \%$ \\
Fibra de vidro & \\
\hline
\end{tabular}

Os dois primeiros componentes compõem a fase matricial do compósito, o carbonato de cálcio atua como carga, a fibra de vidro é o componente estrutural e os demais são aditivos.

De acordo com a Aliança Européia para SMC, instituição que agrega também o BMC, esse tipo de compósito é considerado como um composto inorgânico mais do que um polímero orgânico, (caso seja feito com fibra de vidro) uma vez que a maior parte dos materiais que o constitui são materiais inorgânicos. Em algumas formulações o índice de componentes orgânicos está entre 18 e $25 \%$, o que sugere uma preservação dos recursos naturais.

O volume anual de plásticos reforçados com fibra de vidro na Europa, por exemplo, é de aproximadamente um milhão de toneladas e o SMC e o $\mathrm{BMC}$ representam a maior parte desse total. O maior consumo de SMC/BMC é 
destinado aos segmentos de transporte, eletro-eletrônico, construção civil e outros [European, 2007].

As aplicações do BMC estão associadas a severas solicitações, onde há necessidade de estabilidade dimensional, resistência mecânica e térmica. No caso da fabricação de refletores, as vantagens do material estão associadas à: resistência térmica a temperaturas superiores a $200{ }^{\circ} \mathrm{C}$, baixa ou quase inexistente contração, possibilidade de geometrias complexas quando comparado com refletores metálicos e resistência à corrosão. A relação resistência mecânica/peso, a boa isolação térmica e elétrica, bom acabamento superficial e custo de ferramental relativamente baixo também são muito favoráveis a esse tipo de compósito.

\subsection{PEI - Poli (éter imida)}

As poliimidas são os mais antigos e mais conhecidos plásticos de alto desempenho. Em 1953 a Du Pont depositou a primeira patente de fabricação de uma poliimida a partir do ácido piromelítico e diaminas alifáticas e em 1959 com diaminas aromáticas. A presença de anéis aromáticos na estrutura é uma importante característica dos polímeros de alto desempenho e muitas das propriedades desses polímeros são justificadas por essa característica. Esses anéis aromáticos são ligados por um ou dois átomos e não há presença de grupos parafínicos ou ramificações, o que faz com que a energia para movimentação ou destruição da estrutura seja relativamente elevada.

Semelhante aos demais materiais de alto desempenho, o PEI é um material que apresenta elevada resistência mecânica e térmica numa larga faixa de temperatura, boa estabilidade dimensional, baixa emissão de fumaça, resistência a abrasão e auto retardamento de chama [Gnauck e Frundt,1992].

O peso molecular relativamente alto torna as poliimidas infusíveis e insolúveis. Por esse motivo, os primeiros tipos de poliimidas eram materiais termofixos, porém mais recentemente surgiram materiais derivados das poliimidas que são processados como materiais termoplásticos. A adição de outras matérias primas na síntese das poliimidas como, por exemplo, composto com grupos cetona ou éter permitiu a obtenção de poliimidas termoplásticas. A 
partir desses materiais surgiram produtos tais como lâminas poliméricas de alta resistência térmica, obtidas a partir de sinterização de pós.

A empresa General Eletric, atual Sabic, na década de 60 comercializou as poli (éteres imidas) PESI que foram materiais que antecederam o poli (éter imida) PEI. Outros materiais termoplásticos desenvolvidos nessa época foram a poli (bis maleinimida) e as poli (amida imidas) PAI pela Amoco. As primeiras aplicações das poliimidas foram nos segmentos militares e de aviação, porém atualmente as aplicações são gerais.

O PEI é obtido a partir de uma reação polimerização por condensação de diaminas e dianidridos e pode ser definido como polímero termoplástico amorfo, de alto desempenho principalmente com relação às propriedades mecânicas, térmicas, elétricas, ópticas e químicas, além de ser inerentemente anti-chama. Apresenta elevada resistência química a gasolina, bases diluídas, soluções salinas, alcoóis, ácidos minerais e hidrocarbonetos alifáticos, mas tem a desvantagem de ser atacado por bases fortes e compostos parcialmente halogenados [Costa, 2006].

A empresa Sabic, por exemplo, é fabricante de diferentes produtos termoplásticos, dentre eles o PEI conhecido pelo nome comercial de Ultem. Para identificação desses de materiais a empresa disponibiliza para o mercado diferentes versões onde normalmente existe uma alteração na formulação, proporcionando diferenças de propriedades, aumentando o leque de aplicações.

Esses diferentes tipos de formulações, a partir de uma resina base, são chamados de grades, os quais são identificados com códigos que permitem identificar quais as suas possíveis formulações. Por exemplo, o PEI fabricado pela Sabic das séries 1000 e 2000 é um material sem fibra de vidro para aplicações gerais, enquanto que os materiais das séries 3000 e 4000 possuem fibra de vidro em suas composições e os da série 5000 apresentam resistência química melhorada. Existem outras séries desenvolvidas para fins específicos.

No presente estudo foi abordado o PEI, que é o material termoplástico comumente empregado na fabricação de refletores de faróis automobilísticos. A Figura 4.10 ilustra algumas aplicações do $\mathrm{PEI}$ dentre elas refletores metalizados [Sabic, 2009]. 


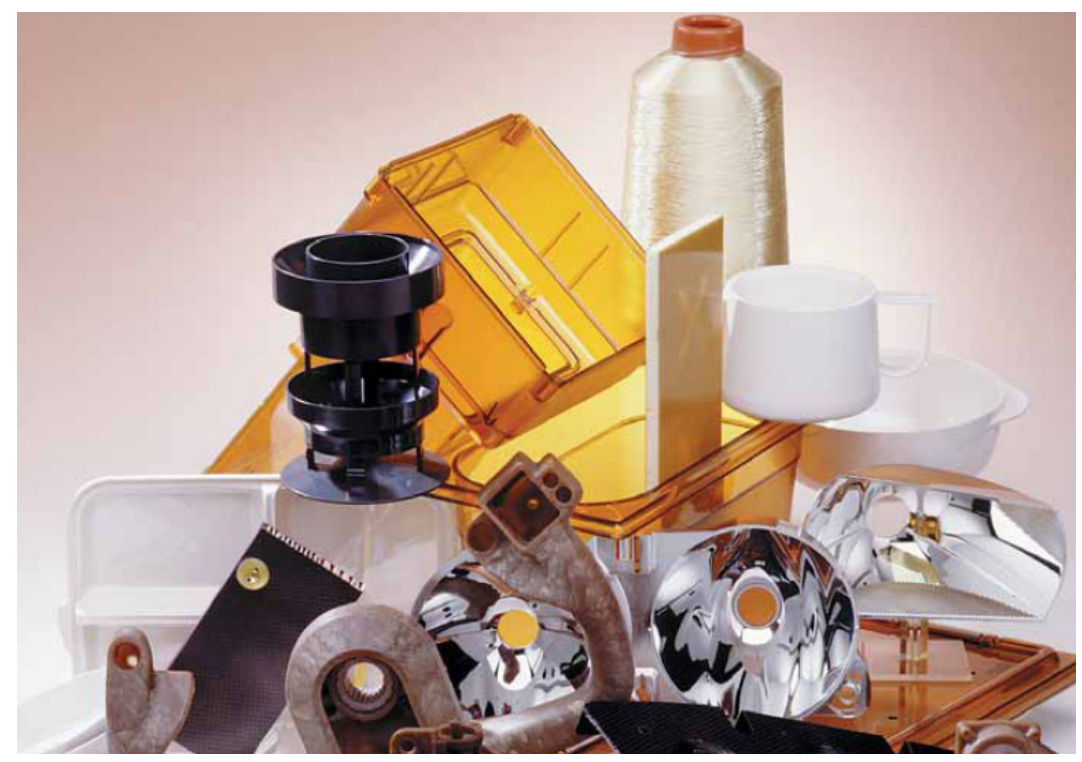

Figura 4.10 - Aplicações do PEl [Sabic, 2009].

Considerando as possíveis formulações (grades), o PEI apresenta ainda elevada resistência térmica (temperatura de transição vítrea de $217{ }^{\circ} \mathrm{C}$ ), inerente resistência a chama, excelente módulo e resistência mecânica em elevadas temperaturas, boa resistência a produtos químicos como, por exemplo, fluidos de freios, hidrocarbonetos halogenados, alcoóis e soluções aquosas, excelente estabilidade dimensional, baixa fluência e baixo coeficiente de expansão térmica, excelente processabilidade com tolerâncias de moldagem bastante restritas. A esse material pode ser adicionado tanto fibras de vidro quanto fibras de carbono, permitindo a fabricação de compósitos termoplásticos. Apesar de apresentar boa resistência química é parcialmente solúvel em solventes halogenados.

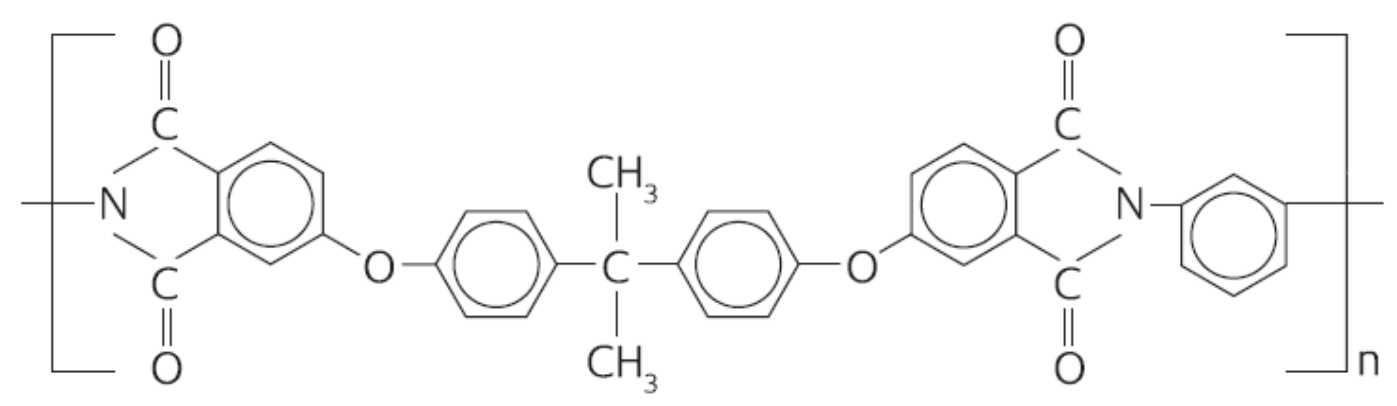

Figura 4.11 - Estrutura geral do poli (éter imida). 
Para o processamento do PEI há necessidade de secagem sendo que as temperaturas de fusão/processo estão entre 340 e $425{ }^{\circ} \mathrm{C}$. Os processos de transformação mais comuns para o PEI são a injeção e a extrusão. As peças confeccionadas com PEI não requerem recozimento, o que é uma vantagem significativa em termos de produtividade. O PEI pode ser aplicado nos segmentos médico, doméstico, aeronáutico, iluminação automobilística, elétrico e telecomunicações.

O principal motivo da utilização do PEI para confecção de refletores de farol automobilístico é a resistência térmica, pois as lâmpadas utilizadas na grande maioria dos faróis são incandescentes, envolvendo o meio num ambiente de alta temperatura. Assim, a proximidade da lâmpada com o refletor gera uma solicitação térmica no material.

Um parâmetro importante que estabelece a resistência do material a essa solicitação é a temperatura de deflexão térmica (HDT), que avalia o quanto o material resiste a um aumento controlado de temperatura sob determinada aplicação de pressão sem se deformar. A Figura 4.12 ilustra um equipamento usado no ensaio de determinação da temperatura de deflexão térmica de um polímero.

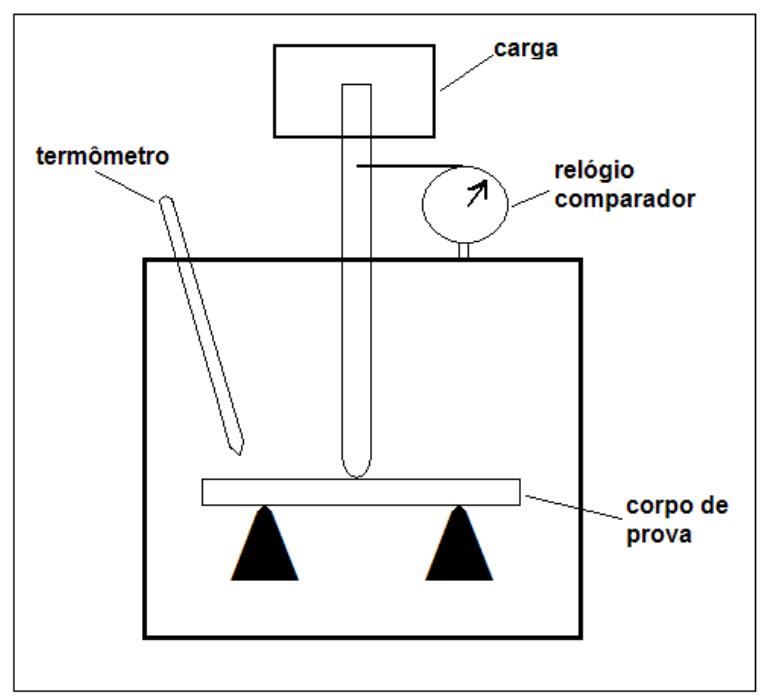

Figura 4.12 - llustração de um equipamento de HDT.

A Figura 4.13 [Sabic, 2009] mostra que à medida que a pressão é aumentada sobre o material, menor é a temperatura na qual o mesmo irá se deformar. Esse conhecimento é importante para se determinar os limites de 
resistência à deformação do material em função da temperatura, pois no caso de um refletor a mínima deformação poderá alterar os ângulos em que os raios de luz serão emitidos e provocar problemas no adequado funcionamento do farol.

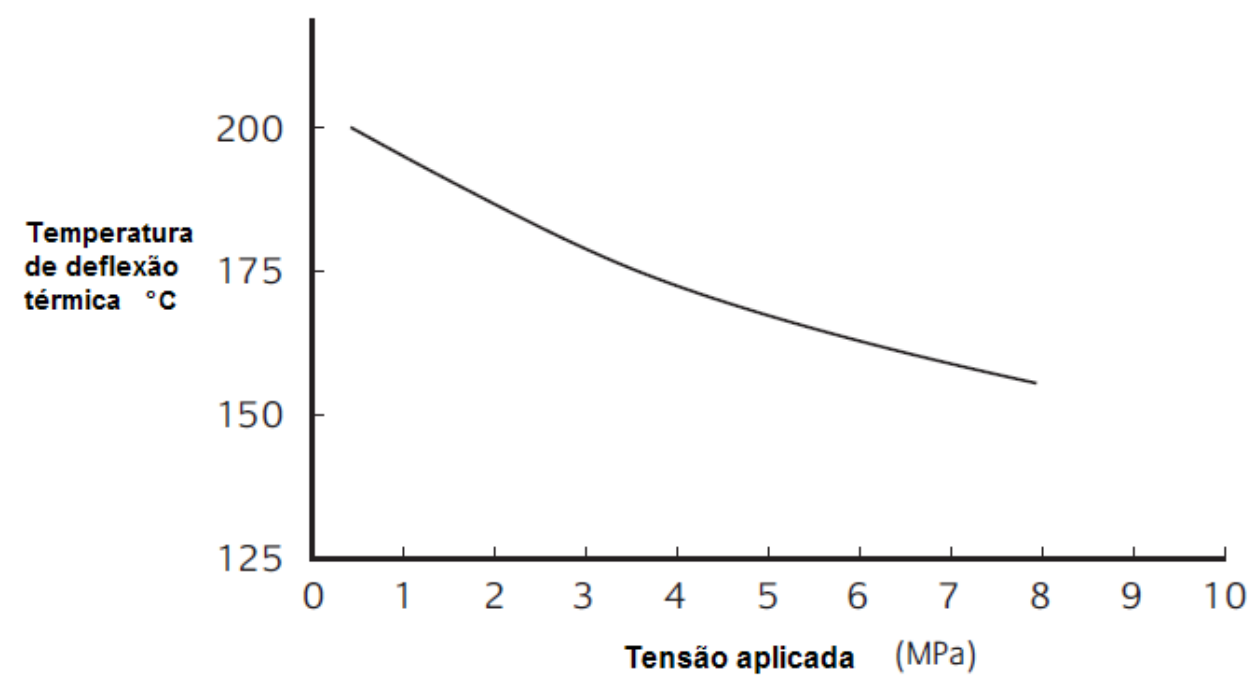

Figura 4.13 - Tensão aplicada em função da temperatura de deflexão térmica [Sabic, 2009].

Embora a temperatura de deflexão térmica seja um parâmetro importante para a aplicação proposta do presente trabalho, esse não é o único parâmetro considerado para que o PEI seja usado em suas outras aplicações.

Existem materiais como o PPS e o PET que apresentam temperatura de deflexão maior que a do $\mathrm{PEI}$ e não são usados para confecção de refletores. $\mathrm{O}$ PPS e o PET não são usados para confecção de refletores porque não reúnem as mesmas propriedades do PEI como, por exemplo, processabilidade e possibilidade de metalização. O PEI também exibe boa resistência a tração mesmo com variações expressivas de temperatura conforme exibido na Figura 4.9 [Sabic, 2009]. 


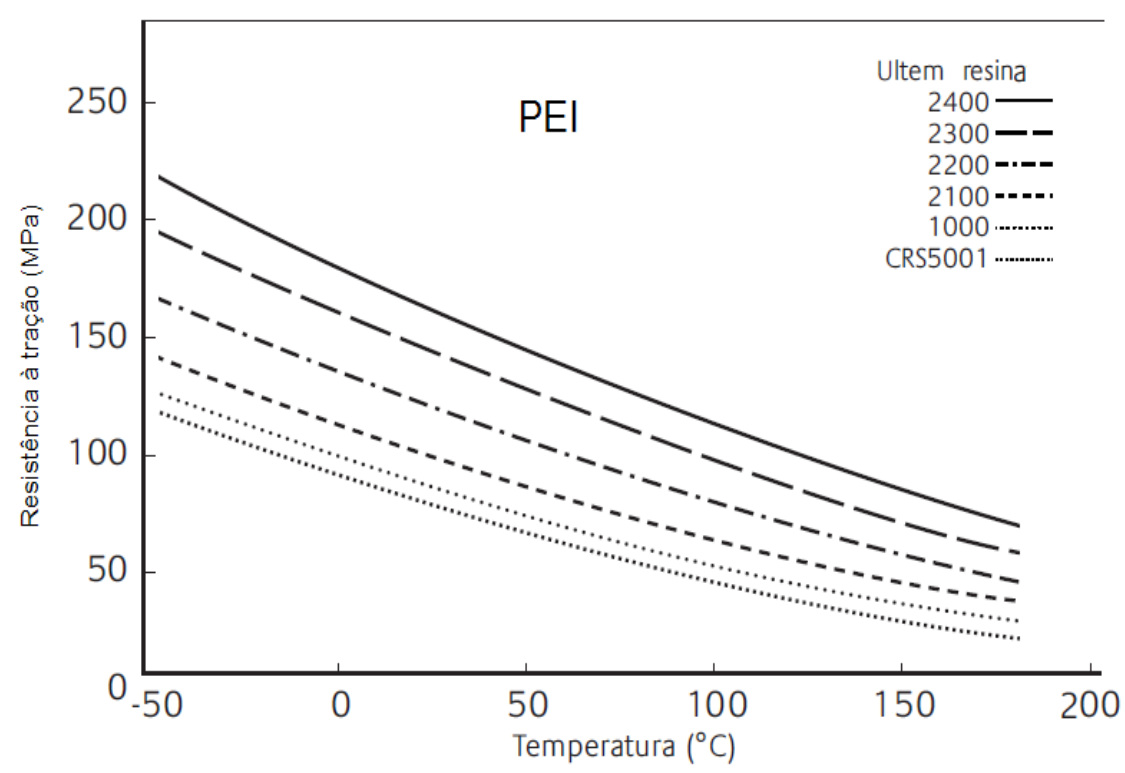

Figura 4.13 - Resistência a tração em função da temperatura [Sabic, 2009].

O gráfico mostrado na Figura 4.13 traz uma informação muito importante. A temperatura de $-50{ }^{\circ} \mathrm{C}$ o material apresenta elevada resistência à tração e com o aumento gradativo da temperatura essa resistência diminui quase que linearmente, o que não acontece com muitos outros termoplásticos.

A diferença de resistência entre os tipos de PEI é justificada pelas variações nas formulações do material, como é o caso do Ultem 2400 que possui fibra de vidro em sua composição, ao contrário da série 1000 e 1100 que não apresentam fibra de vidro. Atualmente no mercado de refletores, o PEI responde por apenas $10 \%$ do consumo, justificado possivelmente pelo alto preço da matéria prima.

A Tabela 4.2 [Harper, 2004] apresenta algumas propriedades de diferentes polímeros termoplásticos que permitem uma comparação com as propriedades do $\mathrm{PEI}$. 
Tabela 4.2 - Comparativo de propriedades de termoplásticos [Harper, 2004].

\begin{tabular}{lccccccc}
\hline & $\begin{array}{l}\text { Temperatura } \\
\text { de deflexão } \\
\text { térmica a } \\
1,82 \mathrm{MPa} \\
\left({ }^{\circ} \mathrm{C}\right)\end{array}$ & $\begin{array}{c}\text { Resistência } \\
\text { à tração } \\
\text { Material }\end{array}$ & $\begin{array}{c}\text { Módulo } \\
\text { de tração } \\
\mathrm{GPa}\end{array}$ & $\begin{array}{c}\text { Resistência } \\
\text { ao impacto } \\
\mathrm{J} / \mathrm{m}\end{array}$ & $\begin{array}{c}\text { Densidade } \\
\mathrm{g} / \mathrm{cm}^{3}\end{array}$ & $\begin{array}{c}\text { Rigidez } \\
\text { dielétrica } \\
\mathrm{MV} / \mathrm{m}\end{array}$ & $\begin{array}{c}\text { Constante } \\
\text { dielétrica } \\
60 \mathrm{~Hz}\end{array}$ \\
\hline ABS & 99 & 41 & 2.3 & 347 & 1.18 & 15.7 & 3.0 \\
CA & 68 & 37.6 & 1.26 & 210 & 1.30 & 16.7 & 5.5 \\
PTFE & & 17.1 & .36 & 173 & 2.2 & 17.7 & 2.1 \\
LDPE & 43 & 11.6 & .17 & $\mathrm{NB}{ }^{*}$ & 0.92 & 18.9 & 2.3 \\
HDPE & 74 & 38.2 & & 373 & 0.95 & 18.9 & 2.3 \\
PI & & 42.7 & 3.7 & 320 & 1.43 & 12.2 & 4.1 \\
PP & 102 & 35.8 & 1.6 & 43 & 0.90 & 25.6 & 2.2 \\
PS & 93 & 45.1 & 3.1 & 59 & 1.05 & 19.7 & 2.5 \\
PVC-rigid & 68 & 44.4 & 2.75 & 181 & 1.4 & 34.0 & 3.4 \\
PMMA & 92 & 72.4 & 3 & 21 & 1.19 & 19.7 & 3.7 \\
Nylon 6/6 & 90 & 82.7 & 2.83 & 53 & 1.14 & 23.6 & 4.0 \\
PBT & 54 & 52 & 2.3 & 53 & 1.31 & 15.7 & 3.3 \\
PC & 129 & 69 & 2.3 & 694 & 1.20 & 15 & 3.2 \\
PEEK & 160 & 93.8 & 3.5 & 59 & 1.32 & & \\
PEI & 210 & 105 & 3 & 53 & 1.27 & 28 & 3.2 \\
PES & 203 & 84.1 & 2.6 & 75 & 1.37 & 16.1 & 3.5 \\
PET & 224 & 159 & 9.96 & 101 & 1.56 & 21.3 & 3.6 \\
PSU & 174 & 73.8 & 2.5 & 64 & 1.24 & 16.7 & 3.5 \\
\hline$*$ Não Quebra & & & & & & &
\end{tabular}

Como pode ser observado na Tabela 4.2, o PEI apresenta, à exceção do PET e do PC na resistência ao impacto, propriedades melhores que todos os outros polímeros, o que favorece sua utilização em produtos onde os requisitos da tabela são exigidos. 
4.6 Materiais usados na confecção de refletores automobilísticos

As empresas que produzem refletores, atentas à questão da reciclabilidade, procuram soluções alternativas para o problema. No caso dos refletores, além do BMC e do $\mathrm{PEI}$, existe a possibilidade do uso poli (éter sulfona) - PES e do polímero de cristal líquido - LCP, esse último não utilizado ainda comercialmente.

Esses materiais apresentam entre si particularidades tanto com relação as propriedades apresentadas como em relação a processabilidade e reciclabilidade o que acaba refletindo diretamente no custo, fator relevante no momento das decisões e estratégias adotadas pelas empresas.

Foi realizado um amplo estudo utilizando materiais termoplásticos [Rosa, 2008] com base em dados de uma empresa produtora de faróis automobilísticos. Nesse estudo, foi traçado um comparativo entre os materiais candidatos à confecção de refletores, no caso, o BMC, o PEI, o PES e o LCP.

A Tabela 4.3 [Rosa et al, 2008] lista os fatores que impactam diretamente no custo dos refletores (valores aproximados no ano de 2004), onde é possível comparar valores e se conhecer porque o custo do BMC é inferior aos demais materiais mesmo apresentando o maior custo por hora por máquina. Os demais materiais (PEI, PES e LCP), todos termoplásticos, não apresentam custo de verniz base pelo fato de não necessitarem de uma camada de verniz antes da metalização, e não apresentam rejeição no envernizamento, além disso, possuem maior número de peças aprovadas, porém o custo de cada um desses materiais é muito superior ao BMC. 
Tabela 4.5 - Comparativo de custo para produção de refletores automobilísticos [Rosa et al, 2008].

\begin{tabular}{|c|c|c|c|c|c|}
\hline \multicolumn{6}{|c|}{ Avaliação do custo da peça acabada } \\
\hline Propriedades avaliadas & & BMC & PEI & PES & LCP \\
\hline Densidade & $\mathrm{g} \mathrm{cm}^{-3}$ & 2,00 & 1,27 & 1,37 & 1,81 \\
\hline Rejeição & $\%$ & 1,50 & 5,00 & 5,00 & 8,00 \\
\hline Preço & $\mathrm{RS} / \mathrm{kg}$ & 4,86 & 22,00 & 22,00 & 24,00 \\
\hline Máquina - custo/h & $\mathrm{RS} / \mathrm{h}$ & 270,00 & 150,00 & 150,00 & 150,00 \\
\hline Tempo de ciclo & s & 60,00 & 48,00 & 45,00 & 40,00 \\
\hline Peças aprovadas $h$ & un $/ \mathrm{h}$ & 104,00 & 138,00 & 150,00 & 160,00 \\
\hline Custo da moldagem $\mathrm{h}$ & RS & 1,44 & 1,29 & 1,29 & 1,29 \\
\hline Custo da metalização/h & RS & 0,65 & 0,65 & 0,65 & 0,65 \\
\hline Custo do vemiz base $/ \mathrm{h}$ & RS & 0,12 & 0,00 & 0,00 & 0,00 \\
\hline Rejeição no envemizamento & $\%$ & 6,00 & 0,00 & 0,00 & 0,00 \\
\hline Rejeição na metalização & $\%$ & 5,00 & 3,00 & 3,00 & 3,00 \\
\hline Limpeza do molde & RS & 0,10 & 0,00 & 0,00 & 0,00 \\
\hline Peças produzidas $\mathbf{h}$. & $\mathrm{un} / \mathrm{h}$ & 60,00 & 75,00 & 80,00 & 90,00 \\
\hline Peso da peça & $\mathrm{kg}$ & 0,358 & 0,227 & 0,245 & 0,324 \\
\hline Custo por peça & RS & 6,92 & 8,59 & 8,97 & 11,45 \\
\hline
\end{tabular}

Os materiais termoplásticos apresentam ainda a vantagem de maior número de peças produzidas por hora e não tem o inconveniente da necessidade de limpeza do molde, e pelo fato desses materiais serem de menor densidade, os refletores são de menor massa, o fator negativo desses materiais é o maior número de peças rejeitadas em comparação com o BMC.

Talvez a comparação do custo unitário das peças não represente uma diferença significativa, porém se for considerada a produção de milhares de automóveis, o valor passa a ser muito relevante nas planilhas de custo das empresas.

\subsection{Metalização}

Uma das etapas de fabricação de um refletor automotivo é a colocação de uma película de metal sobre a peça moldada cuja função é de promover o reflexo da luz gerada pela lâmpada do farol. O reflexo da luz é aumentado e direcionado de acordo com os comandos dados pelo condutor do veículo ao 
funcionamento do farol, no caso luz baixa ou luz alta. Esses comandos seriam impossíveis sem a camada de metal que potencializa a reflexão da luz.

Metalização é o nome dado ao ato de depositar uma fina camada de metal sobre uma superfície. Essa superfície pode ser de plástico, vidro, papel, têxtil ou outros materiais. A camada de metal num processo típico de metalização é bastante fina e para isso o metal deve ser vaporizado, ou seja, fundido e aplicado sobre a superfície. À pressão atmosférica de $1 \mathrm{~atm} 0$ alumínio funde à temperatura de aproximadamente $650{ }^{\circ} \mathrm{C}$ e essa temperatura além de requerer dispendiosas quantidades de energia ainda poderia prejudicar a superfície a ser metalizada. Em função desses fatores, a metalização é realizada em ambiente de pressões negativas, ou seja, é feita a vácuo, o que permite que a temperatura de fusão do alumínio seja bem menor.

A metalização pode ser feita em peças inteiras ou em partes com o auxílio de máscaras que delimitam a área desejada, o que é importante em termos de custo. $O$ processo de metalização em si não é um processo caro e o uso do alumínio contribui para isso, justificando o uso em $90 \%$ dos casos de metalização. Outro aspecto importante da metalização a vácuo usando o alumínio é a possibilidade de se obter cores diferentes com o uso de sais misturados ao próprio alumínio ou até mesmo o verniz pode auxiliar nesse quesito. Além do fator custo, o alumínio gera bons resultados pelo fato de ser vaporizado com facilidade, produzir superfícies bastante brilhantes e não se desprender da superfície ou alterar a cor. A Figura 4.14 [Sabic, 2009] mostra um refletor confeccionado com termoplástico e metalizado.

As principais vantagens da aplicação física de vapor de alumínio são segurança do ponto de vista ambiental pelo fato de não produzir efluentes perigosos e dispensar o tratamento de rejeitos, esse sistema confere a mesma superfície espelhada das peças cromadas e os investimentos são inferiores ao investimento para cromação. 


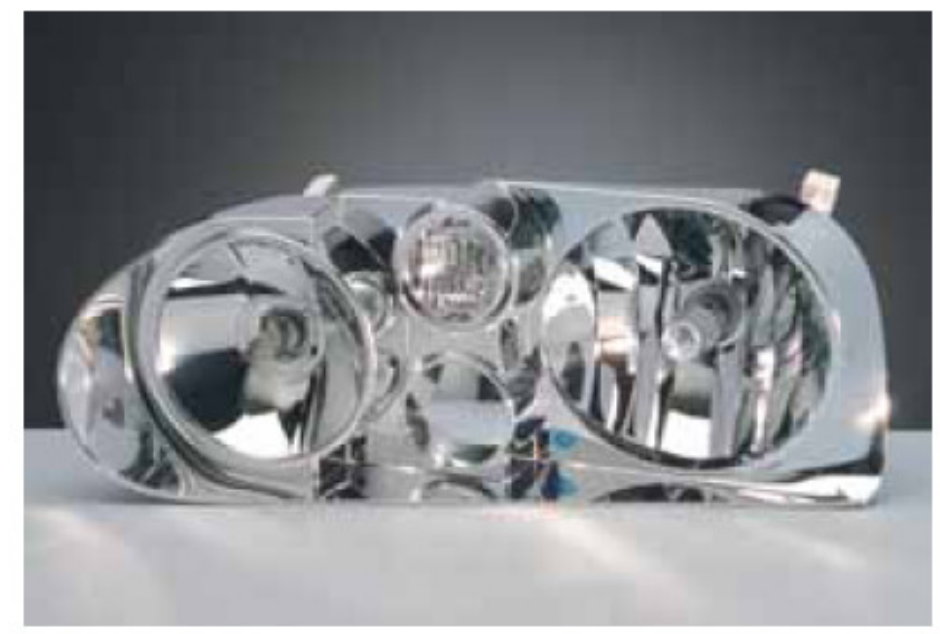

Figura 4.14 - Refletor injetado em PEl e metalizado [Sabic, 2009].

Existem outros processos que permitem a deposição de metal sobe a superfície de uma peça plástica como, por exemplo, a galvanoplastia, mas a metalização a vácuo é mais vantajosa pelo fato de não necessitar que a peça a ser recoberta seja condutora de eletricidade e dispensa acabamentos após a deposição do alumínio.

A cromação é outra alternativa à metalização, mas apresenta alguns problemas principalmente relacionados com questões ambientais, pois pode haver a liberação do cromo hexavalente.

As normas ambientais estão cada vez mais restritivas, como a OSHAOccupational Safety na Health Administration (Agência de Segurança e Saúde Ocupacional do Governo Norte Americano), que determinou que o limite de exposição de partículas de cromo hexavalente é de cinco miligramas de poeira tóxica por metro cúbico de ar, ponderadas por oito horas, o que equivale à cerca de um décimo do limite estabelecido em 1940. Esse limite praticamente levou a indústria automobilística americana uma auto-restrição do uso do cromo hexavalente. Além dos problemas com as questões ambientais o desempenho de peças cromadas pode não ser muito satisfatório quando são submetidas a agentes químicos, principalmente ácidos. Nesse cenário, a deposição do alumínio vaporizado em vácuo é uma excelente opção a cromação.

Apesar dos aspectos citados com relação à cromação, existe um número significativo de empresas que atuam nesse ramo de atividade, ou seja, 
aplicando uma camada de cromo nas superfícies de peças plásticas. Isso se deve a uma tendência verificada nos últimos anos de diversos produtos terem em seus componentes peças metalizadas, como nos segmentos de eletroeletrônicos, cosméticos, mobiliários, sanitários, eletrodomésticos e automobilístico.

Mesmo com as questões ambientais citadas, a Associação Brasileira de Tratamento de Superfície (ABTS) e o Sindicato da Indústria de Superfície, o (Sindisuper) têm buscado uma solução para essa questão procurando formar mão de obra qualificada com apoio de escolas técnicas e desenvolvendo programas de produção mais limpas com apoio do departamento de meio ambiente da FIESP e CETESB [Zaparolli, 2008]. As dificuldades da cromação acabam evidenciando as vantagens da metalização.

O bom resultado da metalização depende da consideração de alguns fatores relacionados à limpeza. A peça a ser metalizada não pode conter pó, óleo, gordura oriunda do contato manual, traços de desmoldante ou qualquer outro tipo de contaminante.

As peças confeccionadas em BMC necessitam receber uma descarga elétrica no estado de plasma que promove alteração na rugosidade da superfície tornando-a irregular, em seguida uma camada de verniz deve ser aplicada para corrigir as rugosidades da peça tornando-a lisa e livre de imperfeições, para finalmente aplicação da camada de metal. Após esse trabalho, uma nova camada de verniz é aplicada com o objetivo de proteger o metal contra a umidade. A Figura 4.15 ilustra a rugosidade e a disposição das camadas do verniz e do metal na superfície de um refletor confeccionado em BMC. 


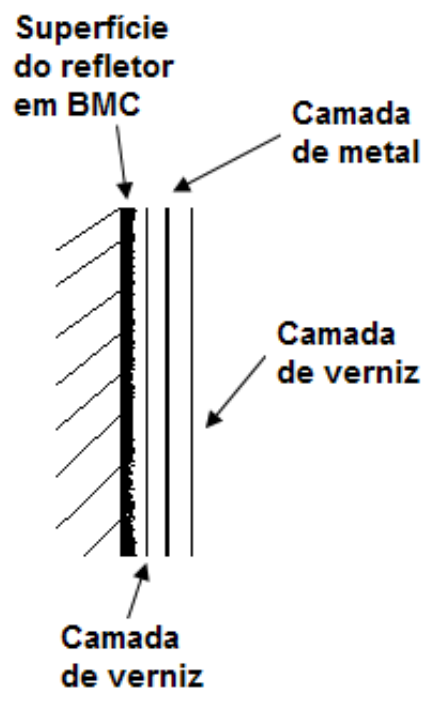

Figura 4.15 - Disposição de camadas de verniz e metal num refletor confeccionado em BMC.

A metalização realça o brilho da peça, o que significa que qualquer imperfeição ou irregularidade superficial mesmo que muito discreta irá interferir nos resultados. Portanto, a função do verniz é corrigir parte dessas possíveis falhas e eliminar os poros ou linhas de fluxo do material formadas durante a moldagem. O PEI não necessita de receber uma camada superficial de verniz pois apresenta boa aderência do metal direto em sua superfície conforme ilustra a Figura 4.15.

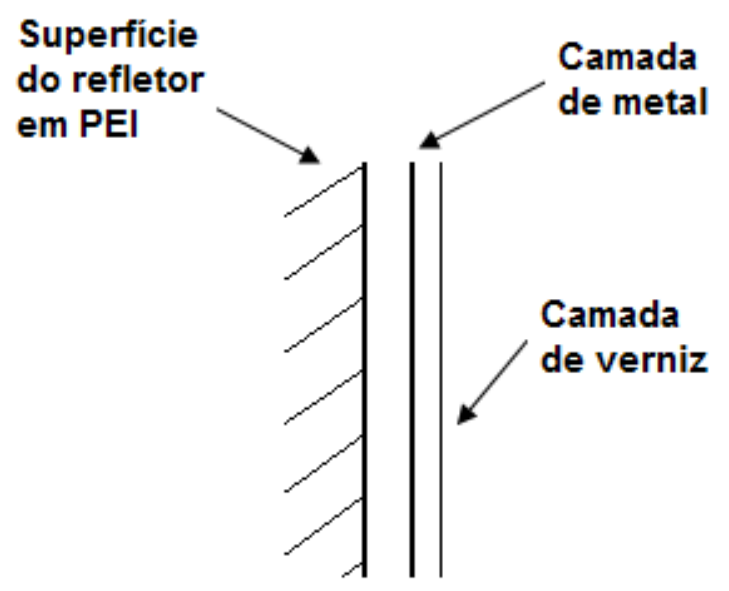

Figura 4.16 - Disposição de camadas de verniz e metal num refletor confeccionado em PEI. 
Os refletores de PEI só recebem a camada de verniz após a metalização Uma provável justificativa para a ausência de verniz no PEl é o fato de ser um material termoplástico isento de fibra de vidro como é o caso do BMC. A presença da fibra de vidro compromete a qualidade da superfície da peça e a metalização não tem por finalidade dar brilho à peça e sim ressaltar com considerável intensidade o brilho já existente.

Materiais plásticos como o $\mathrm{PC}, \mathrm{ABS}, \mathrm{ABS} / \mathrm{PC}, \mathrm{PBT}, \mathrm{PA}$, também podem ser metalizados da mesma forma que o $\mathrm{PEI}$, dispensando a aplicação prévia do verniz. Os vernizes mais utilizados podem ser à base de poliéster, acrílico, epóxi ou poliuretano.

\subsection{Reciclagem de materiais}

Considerando que os materiais do presente estudo são termoplástico e termofixo, respectivamente PEI e BMC, uma curta abordagem sobre reciclagem é feita neste tópico. A reciclagem de materiais é um tema bastante discutido atualmente em função das preocupações com as condições ambientais. A humanidade tem colhido frutos amargos pelo fato de promover a degradação ambiental, consumindo cada vez em maior quantidade os recursos naturais e o resultado prático das diversas discussões acerca do meio ambiente tem sido insuficiente.

Os materiais plásticos têm uma grande importância quando são discutidos os aspectos ambientais, principalmente pelo fato de gerarem quantidades consideráveis de resíduos sólidos, sendo que uma pequena parte do material produzido é reciclada. Em 2006, segundo a Plastivida, que é um instituto sócio-ambiental de plásticos, foram recicladas 520 mil toneladas de termoplásticos, o que equivale a aproximadamente $20 \%$ da produção nacional, sendo que apenas os termoplásticos podem ser reprocessados, enquanto que os termofixos não podem ser reprocessados.

A questão da reciclagem é um fator cada vez mais relevante para diferentes segmentos de produção, dentre eles a indústria automobilística que tem firmado acordos que abrangem as fases de ciclo de vida do veículo, ou seja, não são consideradas apenas a concepção da peça, montagem do veículo e sua funcionalidade frente às solicitações sofridas, mas também 
visando o futuro descarte e reciclagem, inclusive porque o uso de materiais reciclados em muitas aplicações não compromete o desempenho do produto, ou seja, materiais plásticos reciclados apresentam propriedades muito próximas às propriedades do material virgem. $\mathrm{O}$ uso de material reciclado em automóveis tem aumentado nos últimos anos.

$\mathrm{O}$ fato de um produtor de matéria prima desenvolver uma peça em conjunto com uma montadora de veículos visando à obtenção de um produto moderno, e reciclável mostra a importância de haver sinergia e que questões ligadas às condições ambientais não podem ser tratadas isoladamente.

A Tabela 4.5 [Medina, 2002] mostra alguns dos acordos firmados pela montadora Renault em outras frentes relacionadas com os materiais usados na montagem dos veículos. É interessante observar que os acordos envolvem empresas distintas e com objetivos ligados a reciclagem em diferentes partes do veículo, tipo específico de material, momentos do veículo, técnicas de produção, controle de poluição, desenvolvimento de novas tecnologias, enfim um exemplo de possíveis formas de se diminuir os impactos ambientais causados pelos automóveis.

Conforme Andrady, 2003, a reciclagem de materiais termofixos tem sido extensivamente estudada e poucos resultados têm sido alcançados uma vez que o material apresenta características que dificultam o reprocessamento como não poderem ser solubilizados, recompostos ou fundidos mais de uma vez. 
Tabela 4.6 - Acordos em vigor entre a Renault e demais montadoras [Medina, 2002].

\begin{tabular}{|c|c|c|}
\hline Descrição Geral & Parceiros & Objetivos \\
\hline $\begin{array}{l}\text { Assinado em 1992, visa a } \\
\text { reciclagem de carcaças e a troca } \\
\text { de experiências sem } \\
\text { métodos e processos de } \\
\text { reciclaqem. }\end{array}$ & $\begin{array}{c}\text { PSA/ Renault/BMW / } \\
\text { FIAT. }\end{array}$ & $\begin{array}{l}\text { Reciclagem de materiais de } \\
\text { carroceria: veículos fora de } \\
\text { uso. }\end{array}$ \\
\hline $\begin{array}{l}\text { Assinado em 1995, estuda } \\
\text { impactos da poluição e da } \\
\text { desmontagem de veículos sem } \\
\text { a qualidade dos materiais, para } \\
\text { sua integração nos processos } \\
\text { metalúraicos. }\end{array}$ & Renault e Daimler Benz & $\begin{array}{l}\text { Reciclagem de materiais } \\
\text { metálicos }\end{array}$ \\
\hline $\begin{array}{l}\text { Assinado em 1996, no āmbito do } \\
\text { Programa de pesquisa Europeu } \\
\text { sobre Hydro/Gen, } \\
\text { visa obter uma célula combustivel } \\
\text { para um } \\
\text { monospace Peugeot ou Citroen }\end{array}$ & $\begin{array}{l}\text { PSA/ Renault/ Solvay } \\
\text { (Bélgica)/De Nora SpA e } \\
\text { Ansaldo (ltália) }\end{array}$ & $\begin{array}{l}\text { Pesquisa e desenvolvimento } \\
\text { em materiais para } \\
\text { desenvolvimento de novas } \\
\text { fontes de energia }\end{array}$ \\
\hline $\begin{array}{l}\text { Assinado em 1997: cooperação } \\
\text { em reciclagem de veículos. A } \\
\text { Renault recicla veículos Volvo na } \\
\text { França, Bélgica, Espanha e } \\
\text { Portugal e a Volvo recicla os da } \\
\text { Renault na Suécia, Noruega, } \\
\text { Finlândia e Dinamarca. }\end{array}$ & Renault / Volvo & $\begin{array}{l}\text { Reciclagem de materiais de } \\
\text { veículos após o fim de sua vida } \\
\text { útil. }\end{array}$ \\
\hline $\begin{array}{l}\text { Assinado em 1994: EUROCAR* } \\
\text { Programa de P\&D em } \\
\text { automóveis sucessor do JRC** } \\
\text { Para definir uma estratégia } \\
\text { global de P\&D européia } 40 \% \\
\text { financiada pela União Européia. }\end{array}$ & $\begin{array}{l}\text { PSA/Renault/BMW / } \\
\text { Daimler/FIAT / Ford / Opel } \\
\text { /Volvo e Volkswagen. }\end{array}$ & $\begin{array}{l}\text { Pesquisa e desenvolvimento } \\
\text { em materiais, despoluição, } \\
\text { sistelmas de gestão de trafego } \\
\text { e técnicas de produção. }\end{array}$ \\
\hline $\begin{array}{l}\text { Assinado em 1998: acordo para o } \\
\text { desenvolvimento de um novo } \\
\text { veículo no ano } 2000 \text { cuja } \\
\text { carroceria seja feita em material } \\
\text { compósito. }\end{array}$ & Renault / Matra & $\begin{array}{l}\text { Pesquisa e desenvolvimento } \\
\text { em materiais conjugados ou } \\
\text { compósitos: novo veículo } \\
\text { monoespace. }\end{array}$ \\
\hline
\end{tabular}

${ }^{*}$ EUROCAR: European Council for Automotive Research and Development ** JRC : Joint Research Commitee criado em 1980

Esses materiais são comumente usados na forma de compósitos e o reprocessamento se dá por moagem, sendo o pó utilizado como carga em outro material termofixo ou até mesmo em alguns materiais termoplásticos. $\mathrm{O}$ uso de compósitos moídos envolve o controle da granulometria do material moído e o tamanho das fibras, pois a reincorporação apresenta acréscimo de propriedades. A reciclagem mecânica de compósitos é um complemento à reciclagem energética e química. 
No caso do BMC, são processados no Brasil cerca de 130 mil toneladas anuais e desse total $10 \%$ são resíduos descartados em aterros sanitários como resíduos classe 2 (classificação segundo a norma brasileira NBR 10004/2004). Isso corresponde a 13 mil toneladas anuais o que representa um custo de descarte de $\mathrm{R} \$ 90$ milhões, devendo-se levar em consideração ainda o longo tempo de degradação da resina que é superior a 50 anos e da fibra de vidro com tempo muito superior.

Esse é um fato relevante considerando que o potencial de crescimento do mercado brasileiro de compósitos é muito grande, pois o consumo per capita é de 0,66 kg/hab/ano contra 6,00 kg/hab/ano na Europa e 4,50 $\mathrm{kg} / \mathrm{hab} / \mathrm{ano}$ nos Estados Unidos. O descarte desses produtos em aterros além de representar um problema ambiental é também um fator de encarecimento do produto uma vez que as empresas pagam taxas cada vez maiores para descartar seus resíduos em aterros.

A não utilização de compósitos é atualmente difícil de ser considerada em face da importância que esses materiais representam levando em conta a fácil conformação, baixo peso, alta resistência específica e de alta durabilidade.

Diversos estudos têm sido feitos no sentido de buscar alternativas para reciclagem desses materiais utilizando a reciclagem mecânica, reciclagem química ou para obtenção de matérias primas e reciclagem energética ou quaternária.

A reciclagem mecânica é o mais simples método de reciclagem a qual consiste no reprocessamento dos resíduos de origem pós industrial ou pós consumo. Esse tipo de reciclagem é o que exige menor investimento inicial dada a justamente em função de sua simplicidade.

A reciclagem química ou para obtenção de matérias primas é caracterizada pelo tratamento químico ou uso de calor para quebrar os resíduos poliméricos em seus componentes básicos. Os polímeros são moléculas grandes caracterizados por unidades químicas simples que se repetem, na maioria das vezes a reciclagem química é uma reação de despolimerização. Em função da complexidade dos sistemas de reciclagem química o seu custo é muito alto principalmente em comparação com a reciclagem mecânica. $O$ uso desse tipo de reciclagem só é justificado quando 
volumes elevados são reprocessados, ou seja, volumes na casa dos milhares de toneladas por ano.

A reciclagem energética ou quaternária é realizada a partir da combustão dos resíduos com o aproveitamento da energia gerada. O principal argumento desse método é a economia de resíduos fósseis, porém há necessidade de se controlar a emissão dos voláteis para que o processo não comprometa as condições ambientais. Esse tipo de reciclagem é importante para os materiais plásticos pelo fato desses materiais apresentarem elevado potencial energético. Um quilograma de material plástico tem em média 14000 BTU/lb de potencial energético quando incinerado.

Os métodos descritos para reciclagem de compósitos termofixos são os mesmos usados para reciclagem de materiais poliméricos termoplásticos. A diferença se dá pelo fato dos materiais termoplásticos poderem ser facilmente reprocessados, com volumes reciclados bem maiores. 


\section{MATERIAIS E MÉTODOS}

\subsection{Materiais}

Os materiais usados no presente estudo foram o BMC e o PEI e as vantagens e desvantagens descritas no capítulo anterior. A Figura 5.1 ilustra um refletor confeccionado em BMC.

As análises das propriedades do material foram realizadas em corpos de prova. Os corpos de prova de PEI foram cedidos pela empresa Sabic, fabricante do material e os corpos de prova de BMC foram cedidos por uma empresa que adquire o material e o transforma em refletores. Os métodos de preparo dos corpos de prova serão posteriormente detalhados.

Os valores de propriedades do BMC e do PEI foram agrupados na Tabela 5.1 obtidos respectivamente de European Alliance for BMC, 2007 e Sabic Innovative Plastics, 2010 a partir de publicações dos fabricantes subdivididas em propriedades mecânicas, térmicas, elétricas, flamabilidade e físico-químicas. O uso desse tipo Tabela com propriedades dos materiais permite além de comparação entre os dois materiais a comparação de valores publicados pelo fabricante e os valores encontrados nos ensaios realizados.

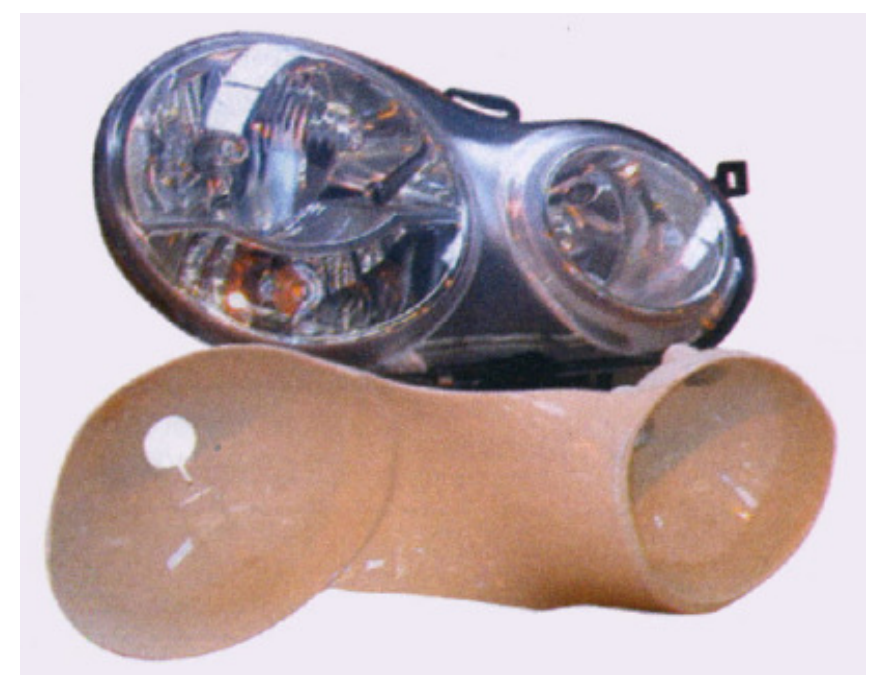

Figura 5.1 Refletor de farol automobilístico confeccionado em BMC. 
Tabela 5.1 - Propriedades do BMC [European, 2007] e do PEI [Sabic, 2009].

\begin{tabular}{|c|c|c|c|c|c|c|}
\hline MÉTODO & BMC & UNIDADE & NORMA & PEI & UNIDADE & NORMA \\
\hline $\begin{array}{l}\text { Resistência a } \\
\text { tração }\end{array}$ & $30-50$ & $\mathrm{MPa}$ & $\begin{array}{c}\text { DIN EN ISO } \\
527.4\end{array}$ & 110 & $\mathrm{MPa}$ & ASTM D 638 \\
\hline $\begin{array}{l}\text { Módulo de } \\
\text { traçăo }\end{array}$ & $7000-16000$ & $\mathrm{MPa}$ & $\begin{array}{c}\text { DIN EM ISO } \\
527.4\end{array}$ & 160 & $\mathrm{MPa}$ & ISO $180 / 1 U$ \\
\hline Alongamento & 0,3 & $\mathrm{MPa}$ & $\begin{array}{l}\text { DIN EM ISO } \\
527 \cdot 4\end{array}$ & & & \\
\hline $\begin{array}{l}\text { Resistência a } \\
\text { flexão }\end{array}$ & $70-120$ & $\mathrm{MPa}$ & $\begin{array}{l}\text { DIN EN ISO } \\
14125-A\end{array}$ & 165 & $\mathrm{MPa}$ & ASTM D 790 \\
\hline $\begin{array}{l}\text { Modulo de } \\
\text { flexão }\end{array}$ & $7000-14000$ & $\mathrm{MPa}$ & $\begin{array}{c}\text { DIN EN ISO } \\
14125-A\end{array}$ & 3520 & $\mathrm{MPa}$ & ASTM D 790 \\
\hline $\begin{array}{l}\text { Resist. a } \\
\text { compressão }\end{array}$ & $40-120$ & $\mathrm{MPa}$ & ISO 14126 & 一 & - & - \\
\hline $\begin{array}{l}\text { Módulo de } \\
\text { compressão }\end{array}$ & $7000-12000$ & $\mathrm{MPa}$ & $\begin{array}{c}\text { DIN EM ISO } \\
604\end{array}$ & 一 & 一 & - \\
\hline $\begin{array}{l}\text { Resist. ao } \\
\text { impacto } \\
\text { Charpy }\end{array}$ & $15-40$ & $\mathrm{KJ} . \mathrm{m}^{2}$ & $\underset{179-1}{\text { DIN EN ISO }}$ & 3 & $\mathrm{KJ} / \mathrm{m}^{2}$ & ISO $1801 \mathrm{~A}$ \\
\hline $\begin{array}{l}\text { Temperatura } \\
\text { de deflexão } \\
\text { sob carga } \\
\text { (estabilidade } \\
\text { dimensional) }\end{array}$ & $>200$ & - $\mathrm{c}$ & ISO $75-2 A$ & 190 & ${ }^{\circ} \mathrm{C}$ & ISO $75 / \mathrm{Ae}$ \\
\hline $\begin{array}{l}\text { Coeficiente } \\
\text { de expansăo } \\
\text { térmica } \\
\text { linear }\end{array}$ & $9-12$ & $10 E-6 . K \cdot 1$ & ISO $11359-2$ & 一 & - & - \\
\hline $\begin{array}{l}\text { Indice de } \\
\text { temperatura }\end{array}$ & 160 & $\cdot c$ & IEC $60216-1$ & 一 & 一 & - \\
\hline Densidade & $1,6-2,1$ & $\mathrm{Kg} \cdot \mathrm{m}^{3}$ & ISO 1183 & 1,27 & g. $\mathrm{cm}^{3}$ & ISO 1183 \\
\hline Contração & $0-0,2$ & $\%$ & ISO 2577 & $0,5-0,7$ & $\%$ & $\begin{array}{l}\text { SABIC } \\
\text { Method }\end{array}$ \\
\hline $\begin{array}{l}\text { Absorçăo de } \\
\text { umidade }\end{array}$ & $<0,2$ & $\%$ & ISO 62 & 1,25 & $\%$ & ISO 62 \\
\hline
\end{tabular}

O PEI é um material polimérico termoplástico, classificado como plástico de engenharia de alto desempenho em função das propriedades apresentadas serem superiores às dos plásticos de engenharia comuns tais como 0 policarbonato - PC ou a poliamida 66 - PA 66.

De acordo com Domininghaus, 2003; o PEl é um material que apresenta elevada resistência a tração mesmo que seja isento de fibras de vidro, elevada dureza e rigidez, temperatura de deflexão térmica superior a $200{ }^{\circ} \mathrm{C}$, elevadas temperaturas de serviço, o que permite o uso contínuo em temperaturas de $170{ }^{\circ} \mathrm{C}$, elevada rigidez dieelétrica e é de cor âmbar transparente. 


\subsection{Métodos}

O estudo dos dois materiais foi feito com corpos de prova nas dimensões adequadas para ensaios de resistência à tração, determinação das temperaturas de transição vítrea, temperatura de deflexão térmica, determinação do teor de fibras de vidro e de frações volumétricas no BMC. Foram comparados os métodos de fabricação de cada um dos refletores tanto do $\mathrm{BMC}$, quanto do $\mathrm{PEI}$, procurando citar as principais etapas de produção de cada um dos refletores até a etapa final de montagem do farol. A Tabela 5.2 registra os ensaios realizados nesse estudo.

Tabela 5.2 Ensaios realizados no BMC e no PEl.

\begin{tabular}{|l|c|c|}
\hline \multicolumn{1}{|c|}{ ENSAIOS REALIZADOS } & BMC & PEI \\
\hline $\begin{array}{l}\text { Determinação das frações } \\
\text { volumétricas do compósito BMC }\end{array}$ & $\checkmark$ & \\
\hline $\begin{array}{l}\text { Análise quantitativa por } \\
\text { espectrometria de fluorescência } \\
\text { de raios X }\end{array}$ & $\checkmark$ & $\checkmark$ \\
\hline $\begin{array}{l}\text { Ensaio de calorimetria } \\
\text { exploratória de varredura }\end{array}$ & $\checkmark$ & $\checkmark$ \\
\hline $\begin{array}{l}\text { Determinação da resistência à } \\
\text { tração }\end{array}$ & $\checkmark$ & $\checkmark$ \\
\hline $\begin{array}{l}\text { Determinação da temperatura } \\
\text { de deflexão térmica }\end{array}$ & $\checkmark$ & \\
\hline $\begin{array}{l}\text { Determinação da temperatura } \\
\text { de amolecimento Vicat }\end{array}$ & $\checkmark$ & \\
\hline $\begin{array}{l}\text { Análise termogravimétrica } \\
\text { TGA }\end{array}$ & $\checkmark$ & \\
\hline $\begin{array}{l}\text { Ensaio de calorimetria } \\
\text { exploratória de varredura - DSC }\end{array}$ & & \\
\hline
\end{tabular}




\subsubsection{Corpos de prova de BMC}

O processo de fabricação dos refletores de BMC inicia com a definição da formulação a ser seguida de acordo com as propriedades desejadas para 0 produto final. Os componentes da formulação comumente utilizados são a resina de poliéster, monômero de estireno, catalisador, acelerador, inibidor, carga e fibra de vidro. Esses componentes são colocados num misturador mecânico, ilustrado na Figura 5.2, em uma seqüência e proporções adequadas e mecanicamente agitadas até a mistura adquirir a consistência de uma massa homogênea. A movimentação de hélices apropriadas no interior do misturador proporciona uma homogeneização dos componentes garantindo uma consistência adequada à utilização do material até esses formarem um produto homogêneo. $O$ armazenamento da massa é feito numa sala de temperatura controlada entre 8 e $14{ }^{\circ} \mathrm{C}$, o que impede que a massa não inicie a reação e se pré solidifique antes de ser colocada na máquina injetora.

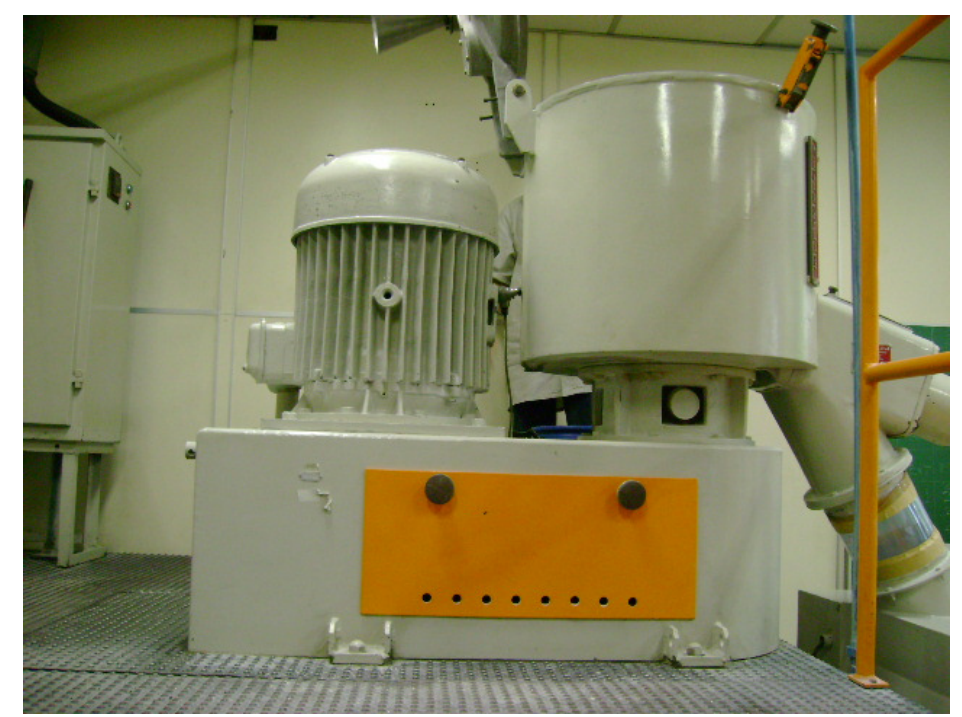

Figura 5.2 - Misturador para BMC.

Os corpos de prova foram obtidos pelo processo de injeção em forma de placa e essa foi posteriormente cortada nas dimensões de acordo com a norma ISO 526 utilizando uma máquina de corte com avanço controlado da mesa e rotação do disco de corte. 


\subsubsection{Corpos de prova de PEI.}

Os corpos de prova de PEI foram obtidos pelo processo de injeção da resina termoplástica seguindo os parâmetros de processo do próprio fabricante. Devido o fato de o material absorver umidade, fato atribuído a estrutura polar do polímero, houve a necessidade de se efetuar a secagem antes do processamento, pois essa umidade é extremamente prejudicial uma vez que as moléculas de água irão apresentar uma energia bastante alta quando o polímero estiver fundido e essa energia é suficiente para comprometer as propriedades do material. A secagem é feita por um período de 4 horas a uma temperatura de $135^{\circ} \mathrm{C}$.

O equipamento usado na secagem do material é o desumidificador, conforme detalhado na Figura 5.3 [Sabic, 2009]. O processo de secagem é iniciado com a definição da temperatura ideal que favoreça o desprendimento das moléculas de água que estão ligadas à estrutura do PEI por ligações de hidrogênio. Uma vez determinada a temperatura de secagem o PEI é alimentado num recipiente que estará ligado à máquina injetora. Na parte inferior desse recipiente que tem a forma de um funil existe uma tubulação que irá conduzir o material numa pequena câmara separada do funil onde está o material apenas por uma placa perfurada que permite apenas a passagem do ar quente sem a passagem de material. $O$ ar aquecido irá aquecer o material e retirará as moléculas de água ali desprendidas. Um desumidificador é um equipamento que trabalha num circuito fechado, ou seja, não pode haver a entrada de ar externo que normalmente apresenta em condições normais quantidades de umidade que podem prejudicar a secagem do material.

Devido ao fato do ar ficar saturado de umidade existe um compartimento com um material higroscópico, normalmente sílica gel, para retirar a umidade do ar do circuito para que esse quando entrar novamente em contato com o PEI apresente o mínimo possível de umidade. Quando a sílica gel fica saturada de umidade o compartimento sairá do circuito para secagem dessa sílica e o fluxo de ar será direcionado para outro ponto onde existe sílica isenta de umidade. 


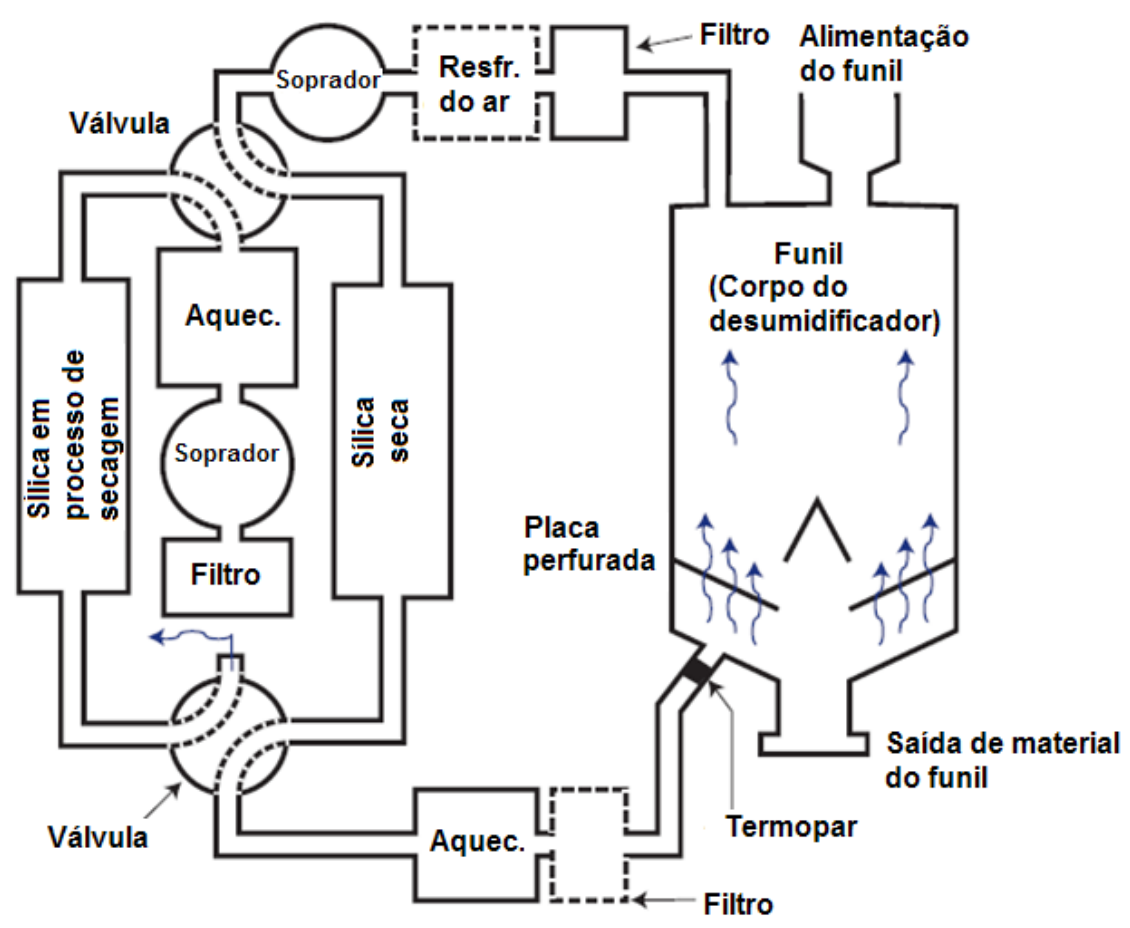

Figura 5.3 - Equipamento para secagem do PEI [Sabic, 2009].

O processo de injeção acontece com a alimentação dos grânulos já secos de material plástico no funil de uma máquina que consiste basicamente numa unidade de injeção onde existe um cilindro de plastificação, muitas vezes chamado de barril, aquecido por resistências elétricas com controle de temperatura. Na parte interna do cilindro de plastificação existe uma rosca sem fim que é responsável pela alimentação do material, plastificação e também é o componente que atuará como pistão para injetar o plástico fundido no interior do molde normalmente bi-partido fixo numa unidade fechamento composto por uma placa fixa e uma placa móvel.

A Figura 5.4 [Andrady, 2003] ilustra alguns detalhes e também as principais etapas do processo, que consiste de: a) fechamento do molde e avanço da unidade de injeção, b) pressão da unidade de injeção sobre o molde e injeção do material fundido no interior do molde, c) recuo da unidade de injeção e tempo de resfriamento para solidificação do material, d) abertura do molde e extração da peça para início de um novo ciclo. 


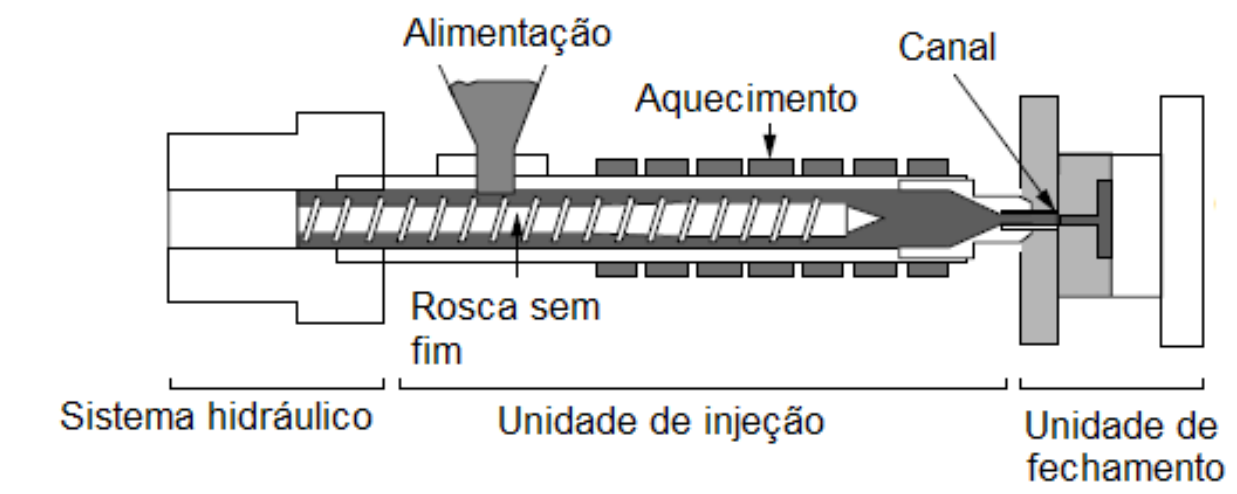

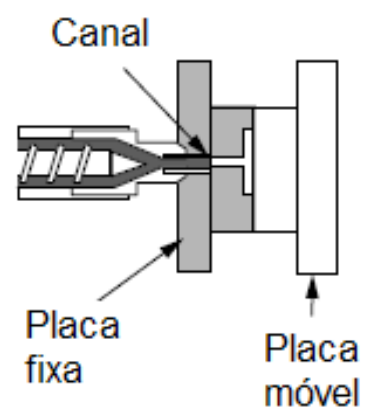

(a)

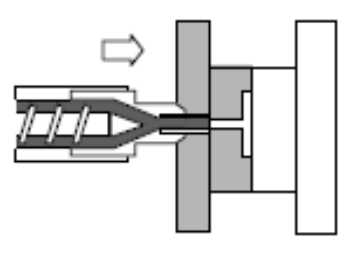

(b)

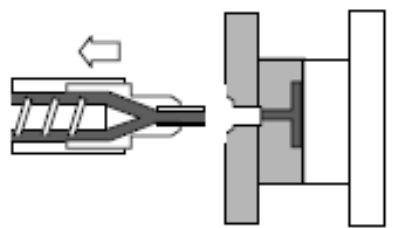

(c)

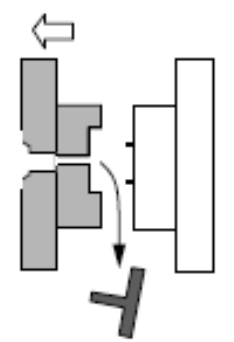

(d)

Figura 5.4 - Esquema de funcionamento de uma máquina injetora [Andrady, 2003].

O processo de injeção é amplamente usado na indústria e permite a obtenção de diferentes peças para os mais diversos segmentos. Num automóvel, diversas peças são obtidas pelo processo de injeção de termoplásticos e no caso os corpos de prova confeccionados para esse estudo. A injeção dos corpos de prova foi realizada em temperaturas entre 332 e $348{ }^{\circ} \mathrm{C}$ e o molde foi aquecido a $120^{\circ} \mathrm{C}$. Essas mesmas condições, com muito poucas alterações são usadas no processamento dos refletores de PEI.

5.2.3 Processos de fabricação dos refletores de PEI e de BMC.

O estudo foi realizado em uma empresa fabricante de refletores e que processa os dois materiais usados para confecção desse produto. 


\subsubsection{PEI}

Do recebimento da matéria prima até os refletores serem entregues para montagem ocorrem as etapas apresentadas de secagem, injeção, inspeção, metalização e aplicação de verniz, conforme ilustrado na Figura 5.5.

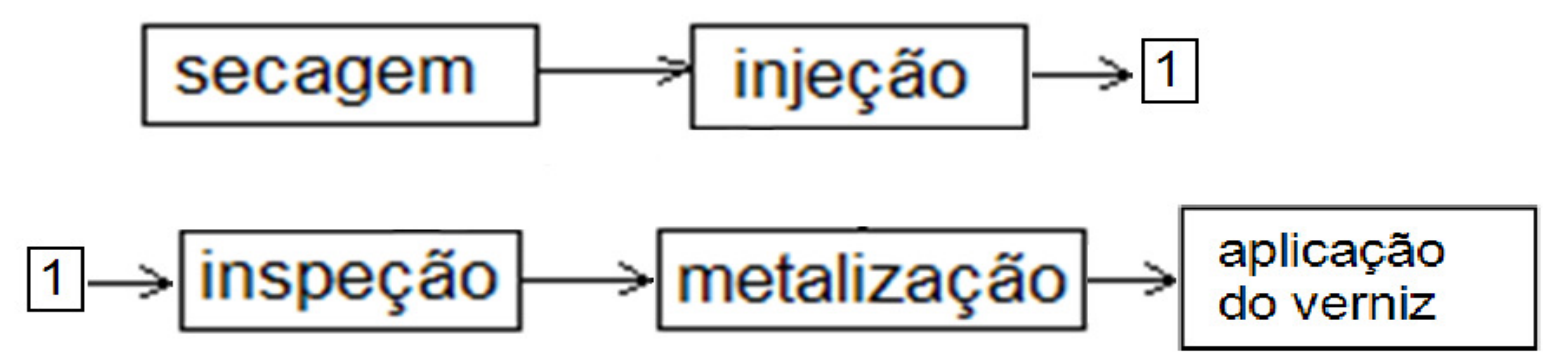

Figura 5.5 - Fluxograma de fabricação de refletores utilizando a resina PEI.

Cada etapa envolve uma quantidade de operações e equipamentos. A secagem, por exemplo, necessita de um desumidificador, que recebe os pellets do PEI por meio de um alimentador. Para a injeção das peças é utilizada uma máquina injetora com um molde que pode ter uma ou duas cavidades, como também um manipulador, cuja função é retirar as peças do molde evitando o contato manual, que interfere na qualidade da metalização. $O$ tempo de ciclo normalmente é de 12 segundos que equivale a uma produção horária de aproximadamente 600 peças.

A inspeção não é realizada em todas as peças (inspeção 100\%), porém o próprio operador da máquina injetora avalia a qualidade de algumas peças. Como os processos de injeção e metalização não são sincronizados devido ocorrerem em locais e equipamentos distintos, há a necessidade de um armazenamento temporário das peças injetadas.

Os materiais plásticos apresentam o sério problema de acumular energia eletrostática e atrair outros corpos de dimensões reduzidas. Esse fenômeno ocorre em diferentes processos de transformação como, extrusão de filmes, granulação, extrusão por sopro. Nesse aspecto, um fator muito importante com relação ao armazenamento é que por melhor que seja o acabamento da peça injetada, se essa for contaminada por poeira ou algo semelhante a peça poderá 
ser rejeitada na etapa de metalização e conseqüentemente causando prejuízos devido ao descarte, caso não atenda as especificações estabelecidas para o refletor metalizado. Diante do exposto, é comum essas peças passarem por um fluxo de ar ionizado para eliminar a carga eletrostática e evitar os possíveis problemas de contaminação no momento da metalização.

Para a etapa de metalização é necessário um equipamento de metalização à vácuo, ilustrado na Figura 5.6 [Prestvacuo, 2009], que recebe as peças e deposita a camada de alumínio conferindo à mesma, aspecto de metal e propriedades de reflexão dos raios de luz provenientes da lâmpada do farol.

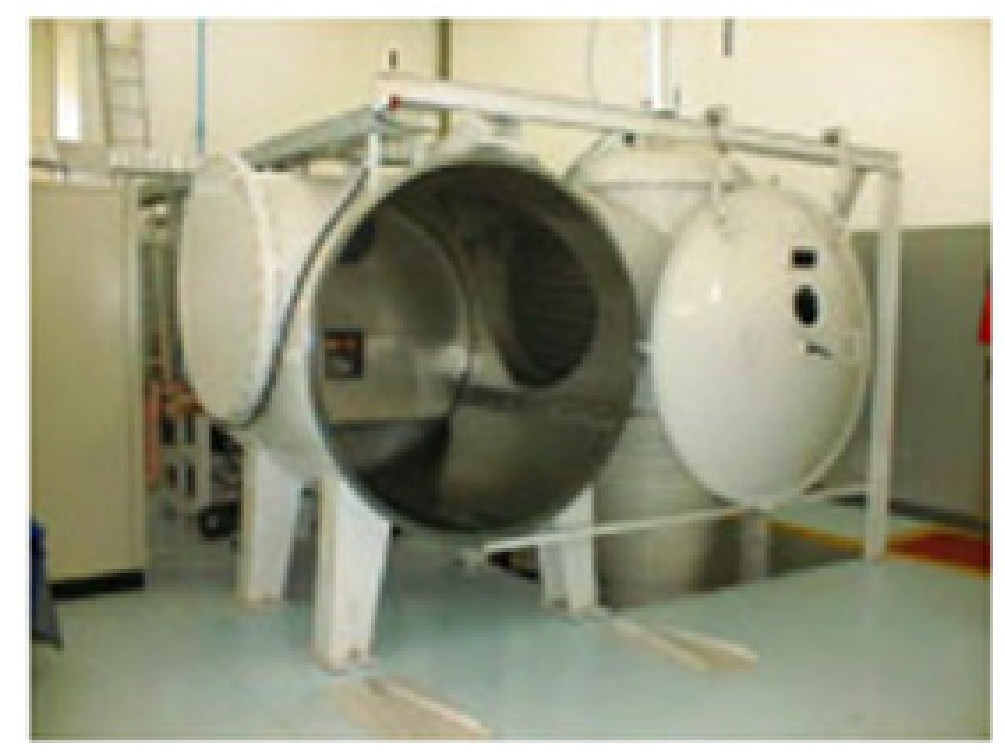

Figura 5.6 - Equipamento para metalização [Prestvacuo, 2009].

É importante ressaltar que as peças injetadas em PEI não necessitam de lavagem e secagem ou mesmo aplicação de verniz para aplicação da camada de metal o que favorece em termos de comparação com o BMC. 


\subsubsection{BMC}

A produção dos refletores em BMC é composta pelas etapas mostradas na Figura 5.7.

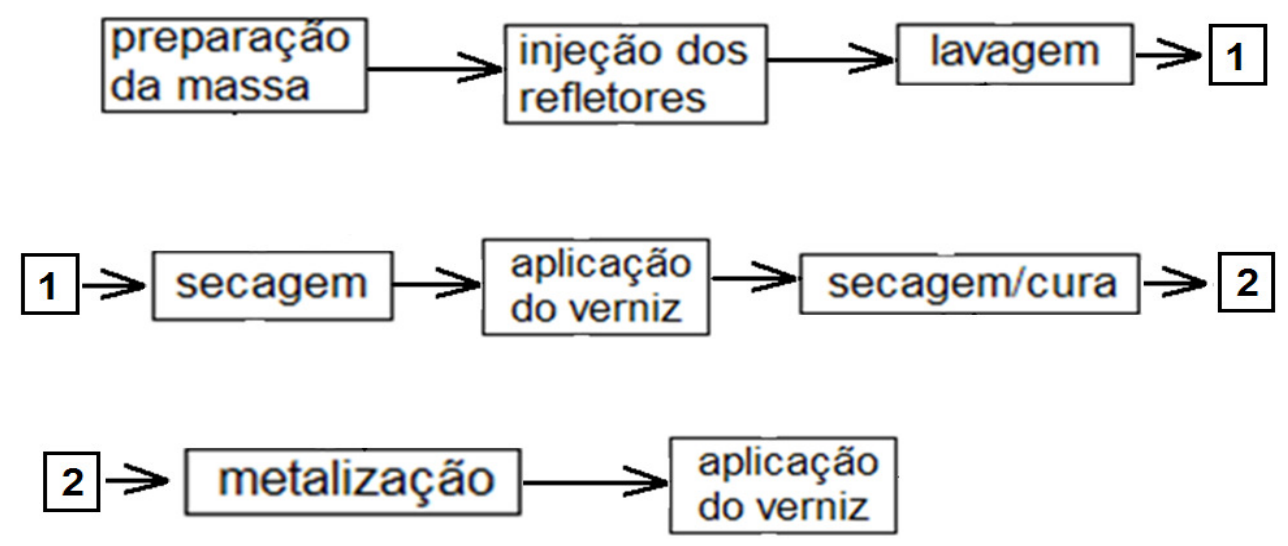

Figura 5.7 - Fluxograma de fabricação de refletores utilizando BMC.

A injeção dos refletores é feita numa máquina que tem funções muito parecidas com uma injetora para termoplásticos. A injetora para o BMC não possui aquecimento e normalmente é resfriado via circulação de água com temperatura de aproximadamente $10^{\circ} \mathrm{C}$. No cilindro (ou barril), ao invés de uma rosca sem fim existe apenas um pistão que irá forçar o material para 0 interior do molde. A cura do material ocorre por conta do aquecimento do molde a qual se situa na faixa de $260{ }^{\circ} \mathrm{C}$ a $300{ }^{\circ} \mathrm{C}$. O conhecimento da temperatura é um fator muito importante com relação ao tempo de ciclo e propriedades apresentadas pelo refletor. Após a injeção o operador retira as rebarbas das peças e as encaminha para a etapa de lavagem. A etapa subseqüente de secagem é importante porque retira o excesso de umidade proveniente do processo de lavagem para que a peça chegue à etapa de aplicação do verniz limpa e seca. A aplicação do verniz tem a função de corrigir possíveis micro-defeitos da superfície do refletor e também proporcionar a ancoragem da camada de metal. Após receber a camada de metal o refletor recebe uma nova camada de verniz que dessa feita terá a função de proteger a camada de metal. 
5.2.4 Determinação das frações volumétricas do compósito BMC

\subsubsection{Calcinação}

O ensaio de calcinação é um método analítico que segue a norma ASTM D 297 e permite quantificar por ação da temperatura o teor de fibra de vidro presente na amostra. Os materiais necessários para realização do ensaio são cadinho de porcelana, pinça e dessecador e ainda uma balança analítica e mufla.

Esse ensaio foi realizado na amostra de BMC, iniciado com a colocação do cadinho na mufla por um período de 15 min para retirada de umidade para evitar qualquer influência no resultado. Após esse período o cadinho foi resfriado e colocado sobre a balança analítica para pesagem da amostra. A análise foi feita em dois corpos de prova distintos conforme ilustrado na Figura 5.8a para se verificar possíveis discrepâncias na distribuição do teor de fibra de vidro. As duas amostras foram colocadas na mufla, ilustradas na Figura $5.8 \mathrm{~b}$, por um período de $2 \mathrm{~h}$ a uma temperatura de $850{ }^{\circ} \mathrm{C}$.

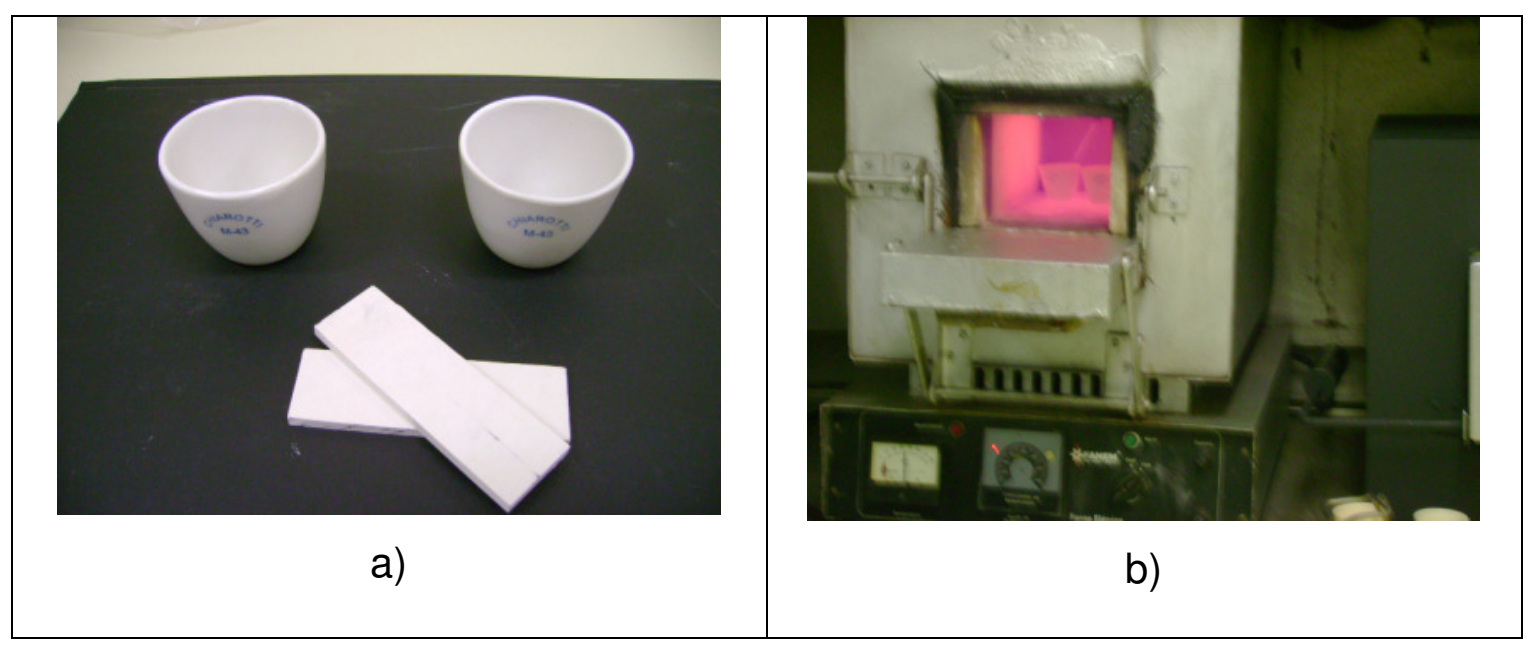

Figura 5.8 Ensaio de calcinação: a) cadinho de porcelana e corpos de prova de BMC, b) mufla para calcinação. 


\subsubsection{Análise quantitativa por espectrometria de fluorescência} de raios $X$.

A análise de espectrometria por fluorescência de raios $X$ foi realizada nos resíduos oriundos da calcinação com o intuito de se determinar qual o teor de materiais inorgânicos estão presentes numa formulação de BMC. Os resultados dessa análise estão expressos na Tabela 5.3. A temperatura de secagem da amostra foi de $110 \pm 5{ }^{\circ} \mathrm{C}$ e a temperatura de perda ao fogo foi de $950 \pm 50{ }^{\circ} \mathrm{C}$.

\subsubsection{Ensaio de resistência à tração}

Os ensaios para determinação da resistência à tração seguem normas que determinam as condições gerais do ensaio, as dimensões dos corpos de prova e as velocidades envolvidas de forma que seja obtida de maneira correta a carga e a deformação. As propriedades obtidas nesse tipo de ensaio são resistência a tração máxima, tensão na força máxima, deformação específica, deformação na ruptura e módulo de elasticidade. Os ensaios de para determinação da resistência à tração dos corpos de prova do PEI e do BMC foram realizados segundo a norma ISO 527 no equipamento ilustrado na Figura 5.9.

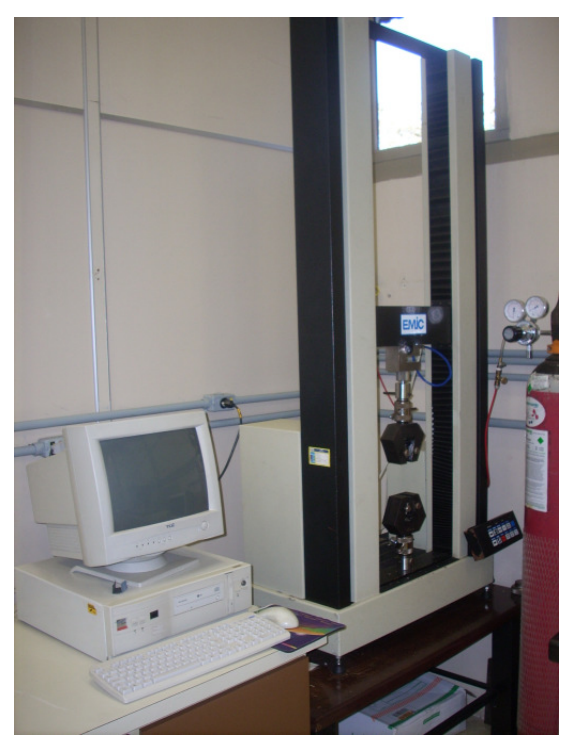

Figura 5.9 - Máquina universal de ensaios mecânicos. 


\subsubsection{Ensaio de DSC}

O ensaio de calorimetria exploratória de varredura foi realizado numa amostra de 7,1g utilizando um aparelho Seiko 6200 EXSTAR 6000, ilustrado na Figura 5.10 conforme a norma ASTM D 3418-03. As temperaturas de aquecimento foram de 20 a $350{ }^{\circ} \mathrm{C}$ com velocidade de aquecimento de $10{ }^{\circ} \mathrm{C} \cdot \mathrm{min}^{-1}$.

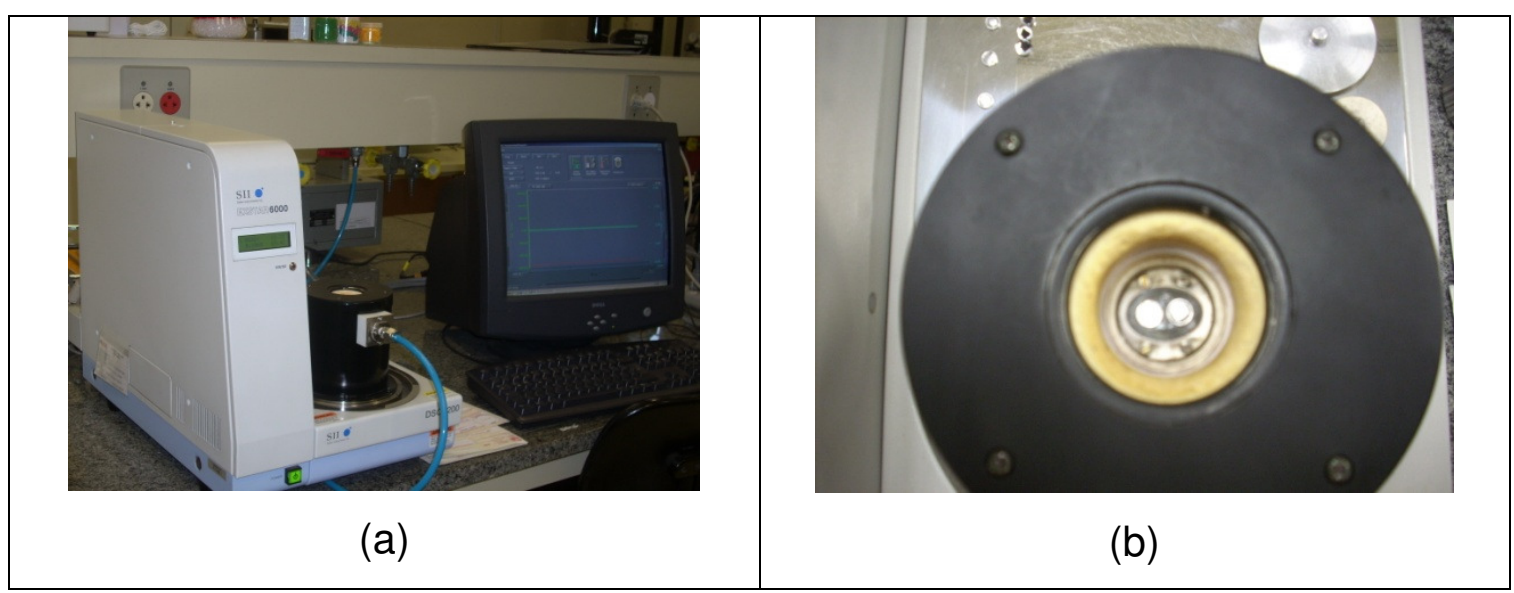

Figura 5.10 - Equipamento de DSC: a) vista geral, b) detalhe da amostra e referência.

5.2.7 Ensaio de temperatura de amolecimento Vicat

O ensaio para determinação da temperatura de amolecimento Vicat em materiais poliméricos permite avaliar a resistência que o material oferece à penetração de uma agulha de $1 \mathrm{~mm}^{2}$ de área numa taxa controlada de aumento de temperatura. A agulha deve penetrar na superfície do corpo de prova exatamente $1 \mathrm{~mm}$, porque esta exerce uma carga padronizada de acordo com a norma. $O$ equipamento monitora a penetração da agulha e quando esta penetra $1 \mathrm{~mm}$ no corpo de prova e o equipamento emite um sinal e informa a temperatura, que está associada ao amolecimento do material. $O$ ensaio foi realizado num equipamento marca Ceast modelo HDT 3 Vicat, com aquecimento de banho de silicone, sendo a taxa de aquecimento e carga conforme a norma ASTM D 1525. 
5.2.8 Ensaio de temperatura de deflexão térmica - HDT

O ensaio de HDT é usado para determinação da temperatura de deflexão térmica e foi realizado num aparelho marca Ceast modelo HDT 3 Vicat, ilustrado na Figura 5.11, que é dotado de aquecimento de banho de silicone. A taxa de aquecimento e a tensão aplicada seguiram as determinações da norma ISO 75 .

O objetivo desse ensaio é determinar a que temperatura ocorre uma deformação específica do corpo de prova quando submetido a uma carga padronizada a uma taxa controlada de aumento da temperatura. Para a norma utilizada, a taxa de aumento da temperatura é de $120{ }^{\circ} \mathrm{C} \cdot \mathrm{min}^{-1}$ e são necessárias 2 amostras, porém no ensaio foram avaliados 3 . $O$ uso de 3 corpos de prova torna a avaliação mais criteriosa e permite detectar diferenças significativas de resistência caso essas existam a partir de uma falha pontual num determinado corpo de prova.

O corpo de prova é apoiado sobre dois pontos nas extremidades e no centro é colocada uma ponta interligada mecanicamente à carga e também a um relógio comparador para se mensurar a deflexão. A carga aplicada e a deflexão dependem das dimensões do corpo de prova.

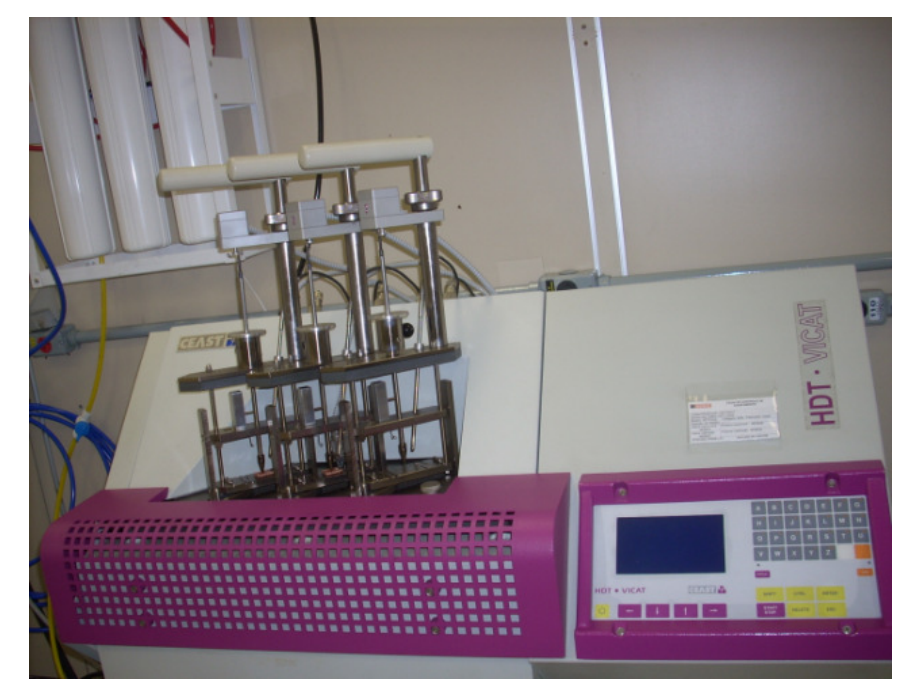

Figura 5.11 - Aparelho para ensaios de HDT e determinação de temperatura Vicat. 


\subsubsection{Ensaio de metalização}

Um dos ensaios solicitados pelas empresas montadoras de veículos segue a norma TL 207 que é subdividida em três ensaios. O primeiro é o de resistência à umidade, conforme a norma DIN 50017 KK, que consiste basicamente em manter a peça metalizada exposta a uma câmara úmida por um período de $48 \mathrm{~h}$. Para peça ser considerada aprovada a metalização não poderá apresentar manchas ou alterações.

O segundo ensaio segue a norma DIN 50014 que consiste em manter a peça metalizada submetida à temperatura de $80{ }^{\circ} \mathrm{C} \pm 3$ por um período de $24 \mathrm{~h}$ com circulação de ar. Em seguida a peça permanece em processo de estabilização por $0,5 \mathrm{~h}$ com temperaturas entre 15 a $35{ }^{\circ} \mathrm{C}$, sendo submetida ainda a temperatura de $-40{ }^{\circ} \mathrm{C}$ por um período de 4 horas. Nessas condições a camada de metalização não poderá sofrer nenhuma deformação ou desplacamento.

O terceiro ensaio segue a norma DIN EN ISO 2409 e consiste em riscar a superfície da peça metalizada perpendicularmente a traços verticais de distância de $1 \mathrm{~mm}$ e posteriormente colar sobre a superfície riscada uma fita adesiva, nesse caso a norma sugere a fita Scotch tipo 810, que em seguida deverá ser retirada. Para a peça ser considerada aprovada a fita adesiva não poderá retirar da superfície riscada nenhum quadradinho de metal da área riscada. Existe uma escala que define quais os níveis de metal que podem ser retirados da superfície de uma peça metalizada, conforme ilustra a Figura 5.12.

\begin{tabular}{|c|c|c|c|c|c|c|}
\hline $\begin{array}{l}\text { Parâmetros de } \\
\text { desplacamento } \\
\text { da metalizaçãoo }\end{array}$ & Ad 0 & Ad1 & Ad2 & Ad3 & Ad4 & Ad5 \\
\hline Representação & --- & 茟制 & 㐩 & 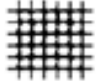 & 戗茟殿 & -- \\
\hline
\end{tabular}

Figura 5.12 - Escala para representação do nível de aderência da camada de metal sobre a superfície do material plástico. 
O parâmetro Ad O é admitido quando após a fita ser colada e retirada da superfície riscada nenhuma partícula da camada de metal é retirada. $O$ parâmetro Ad 1 classifica amostras cuja retirada seja de aproximadamente $5 \%$ da camada de metal depositada sobre a superfície plástica. O parâmetro Ad 2 classifica amostras que apresentem considerável saída de material ao longo de um dos riscos. A Ad 3 é empregado para o caso da camada de metal quebrar total ou parcialmente em alguns quadradinhos e a $\mathrm{Ad} 4$ quando aproximadamente $65 \%$ da camada de metal se desprende da superfície. Finalmente, a classificação Ad 5 é dada quando uma quantidade superior a $65 \%$ da camada de metal se desprende da superfície metalizada. A Figura 5.13 [Rosa et al, 2008].ilustra o ensaio de metalização realizado num refletor.

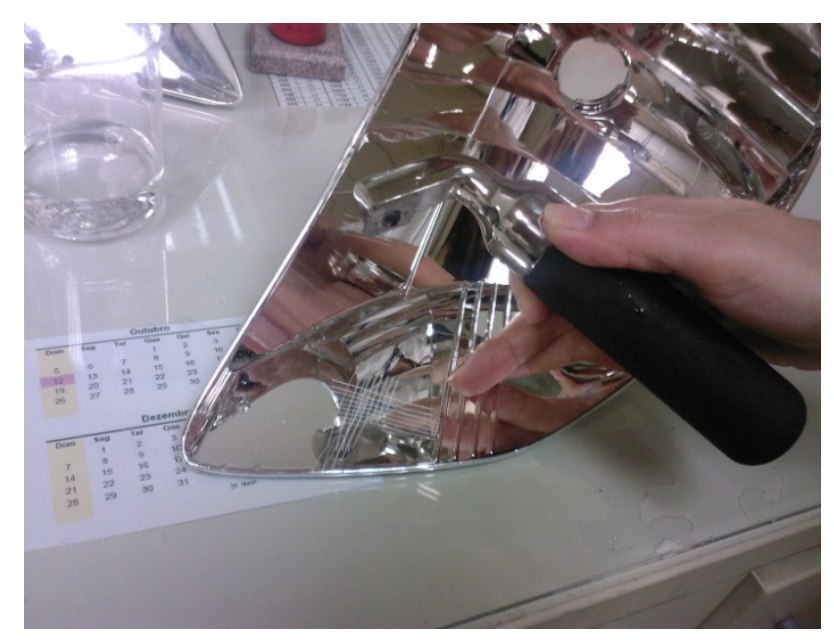

Figura 5.13 - Análise de aderência da camada de metal num refletor [Rosa et al, 2008].

\subsubsection{Análise termogravimétrica - TGA}

O ensaio de termogravimetria tem como objetivo avaliar a perda de massa de uma amostra quando submetida a uma taxa controlada de aumento de temperatura. Com a realização desse ensaio é possível avaliar o comportamento ou alterações na massa da amostra provocada pelo aquecimento, tais como reações de desidratação ou oxidação, combustão, decomposição além de permitir avaliar o teor de resíduos. 
O equipamento, ilustrado na Figura 5.14 que realiza essa análise é provido de uma termobalança, com monitoramento do aquecimento da massa e da temperatura simultaneamente, o que possibilita que as condições experimentais incluindo a atmosfera gasosa sejam variadas significativamente. O controle da atmosfera gasosa é importante porque durante o aquecimento da amostra ocorrem processos físicos e químicos responsáveis pela liberação de produtos voláteis, que podem gerar não só a perda, mas também o ganho de massa a partir da interação da atmosfera existente no forno do equipamento com os gases da amostra.

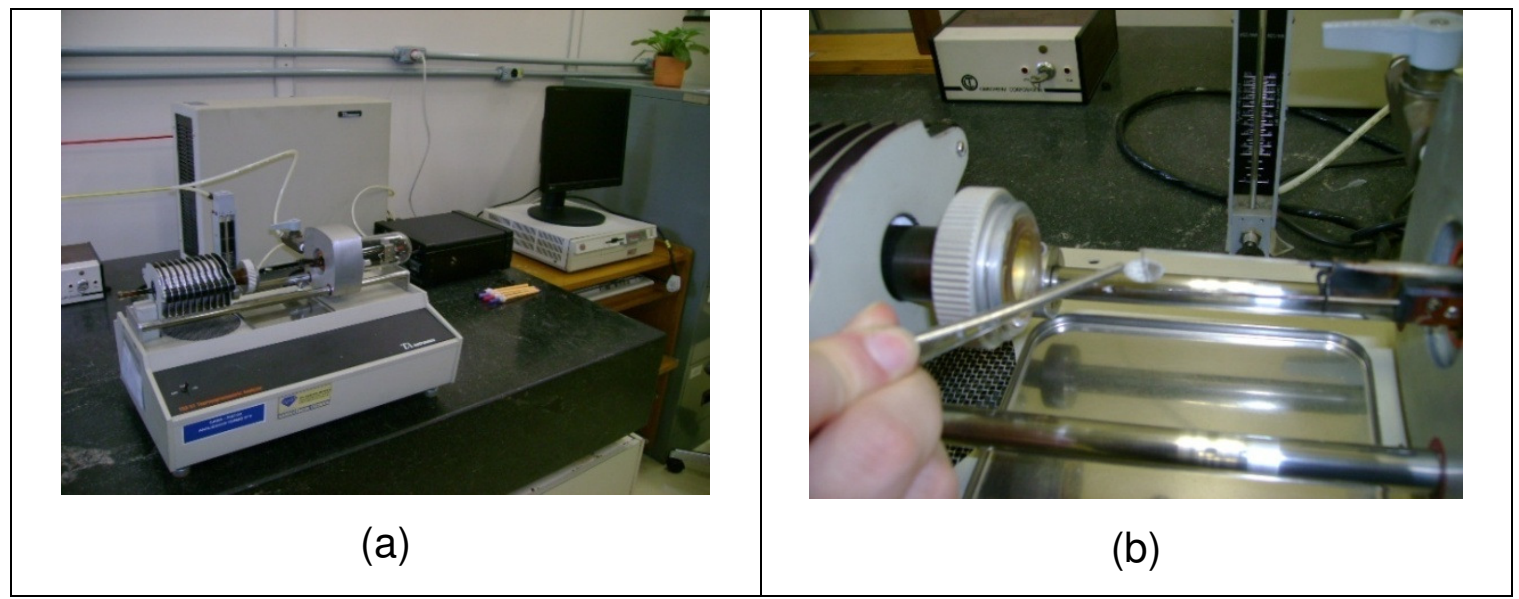

Figura 5.14 - Equipamento para análise de termogravimetria: a) vista geral, b) local para introdução da amostra.

O ensaio foi realizado de acordo com a norma ASTM E 1131, utilizando um equipamento da TA Instruments, modelo TGA 51 Thermogravimetric Analyser.

\subsubsection{Reaproveitamento de resíduos de BMC}

Um dos grandes desafios para a empresa que utiliza materiais termofixos é a dificuldade no reaproveitamento desses materiais, atribuída à cura que forma uma reticulação (crosslinking) entre as macromoléculas. 0 destino de produtos fabricados com resinas termofixas tem sido os aterros sanitários. Para o descarte as empresas pagam valores significativos, que embora seja um procedimento legalmente justificado, poderá num futuro 
próximo criar uma imagem negativa da empresa devido às pressões das organizações ambientalistas.

Com foco nesse problema, foram feitos estudos utilizando resíduos moídos de BMC para posterior incorporação em outros materiais. Essa atitude não é recente, uma vez que já existe há algum tempo empresas que realizam a moagem dos materiais termofixos e os incorporam como carga em resinas termofixas.

Os resíduos de BMC podem ser gerados nas diversas etapas do processo de obtenção dos refletores, que podem ser constituídos de rebarbas, peças incompletas, peças com a camada de verniz e peças com verniz e metalizadas, conforme ilustra a Figura 5.15.
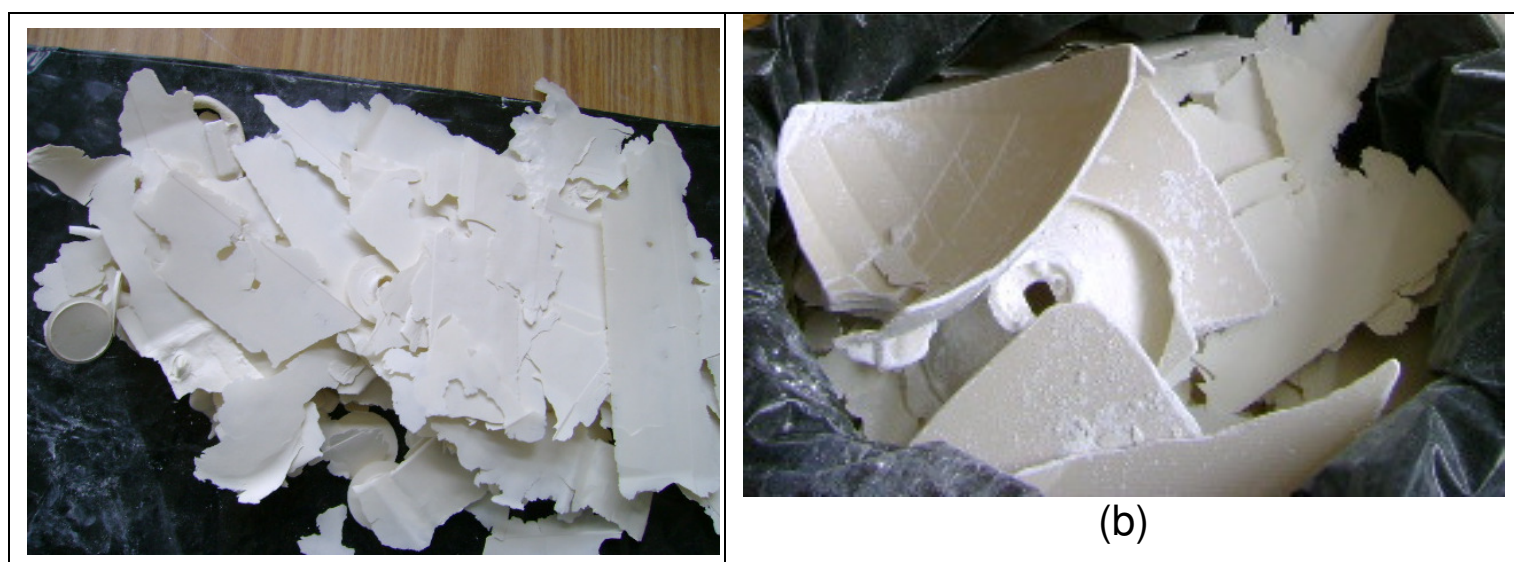

(a)

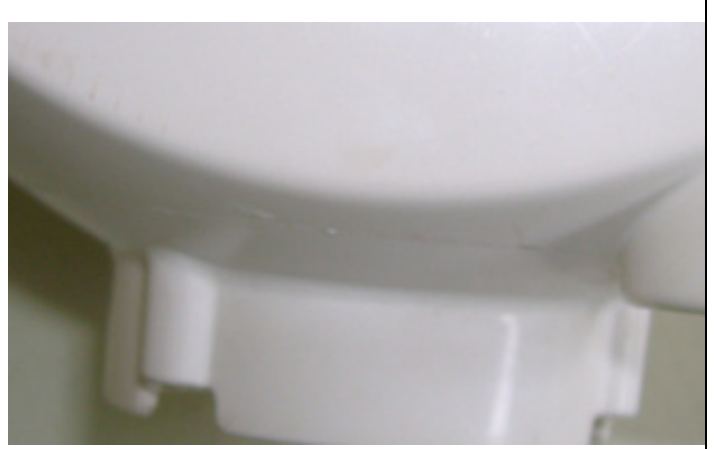

(c)

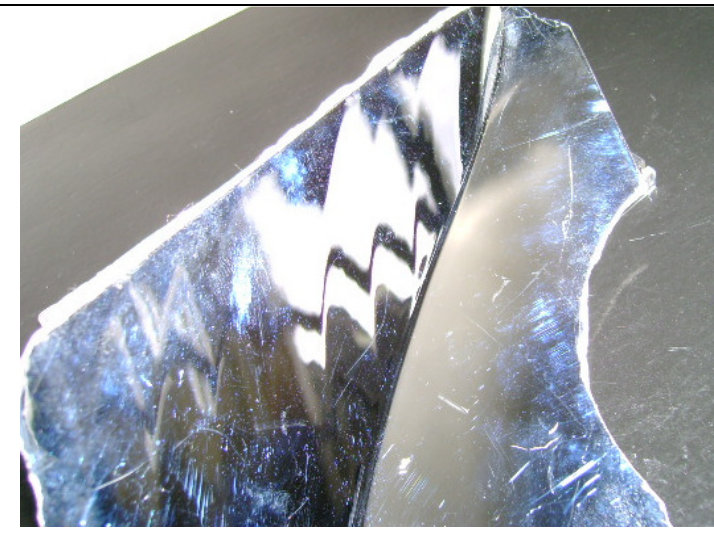

(d)

Figura 5.15 - Rejeitos de peças em BMC: a) rebarbas, b) peças incompletas, c) peças incompletas com verniz, d) peças metalizadas. 
O presente estudo promoveu a moagem dos rejeitos do material termofixo utilizando equipamentos não convencionais para essa atividade, no caso moinhos destinados ao processamento de material cerâmico, o que de certo modo consistiu numa nova alternativa à moagem de termofixos.

O primeiro teste foi feito num "moinho de panelas" o qual consiste de uma peça cilíndrica construída em metal com outras peças cilíndricas que giram excentricamente na parte interna. O problema foi o pequeno volume de material, que impediria um ensaio mais consistente com os resíduos. A opção para de ter um maior volume de material para os testes foi utilizar um moinho também destinado ao processamento de materiais cerâmicos, no caso um moinho de bolas, o qual é construído de porcelana, com esferas de diferentes diâmetros colocadas na parte interna conforme ilustra a Figura 5.16. Para se ter melhor aproveitamento do volume do moinho, as peças foram cortadas numa serra de fita, mas para se ter mais informações sobre a eficácia da moagem foram colocados pedaços grandes.

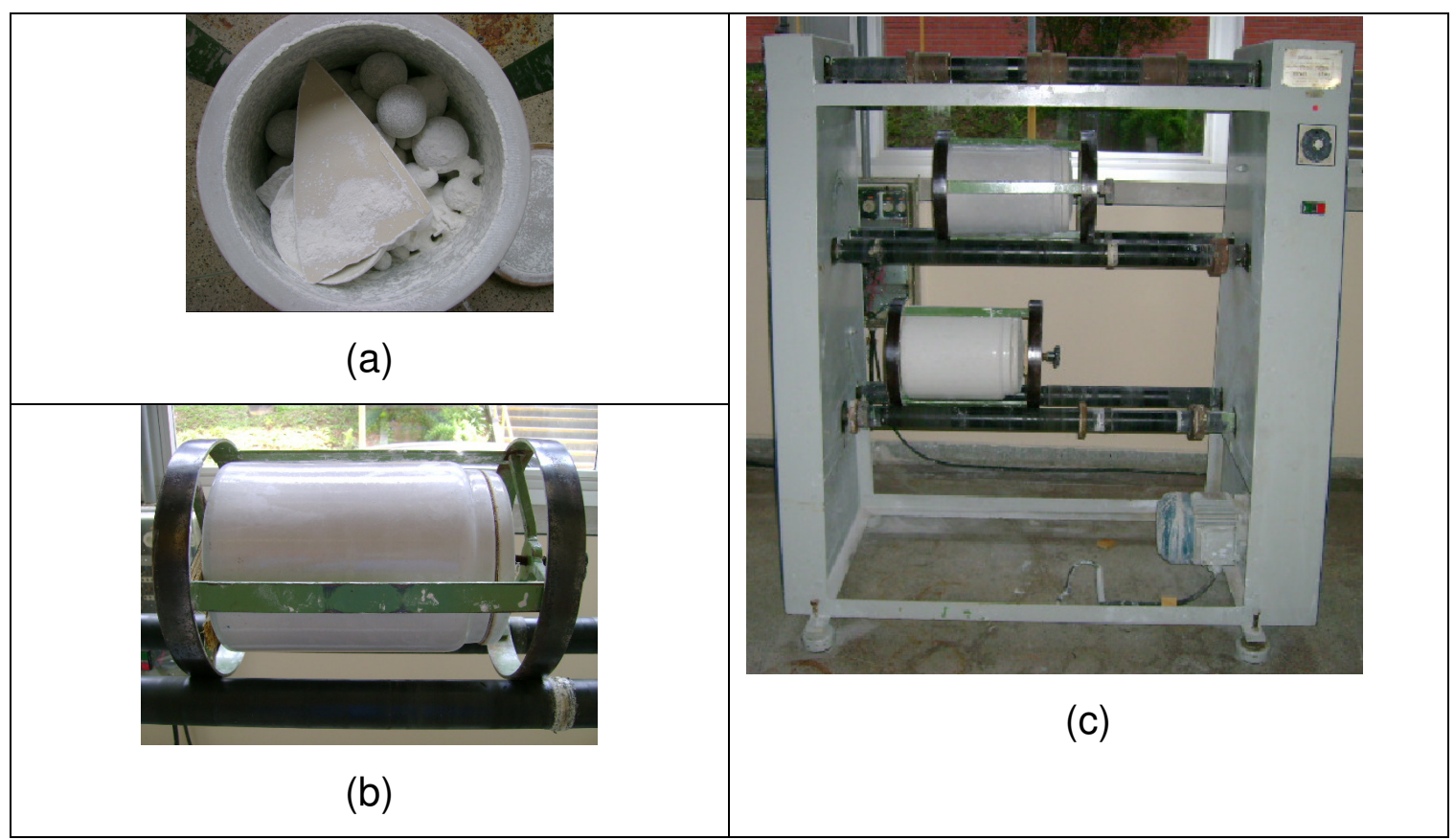

Figura 5.16 - Moinho de bolas: a) Recipiente de porcelana com os seixos e as peças em BMC, b) Recipiente em posição para girar e moer, c) Vista do equipamento em funcionamento. 
Foram usados dois recipientes semelhantes aos da ilustração 5.16 e o tempo de movimentação com o giro dos moinhos foi de $5 \mathrm{~h}$. Após a moagem restaram ainda pedaços grandes os quais foram peneirados numa peneira de malha 20 mesh, ilustrada na Figura 5.17, onde é possível visualizar o pó com uma granulometria reduzida e os pedaços de BMC que sobraram. A maior parte dos pedaços maiores foi moída, porém sobraram alguns pedaços conforme aparece na ilustração.

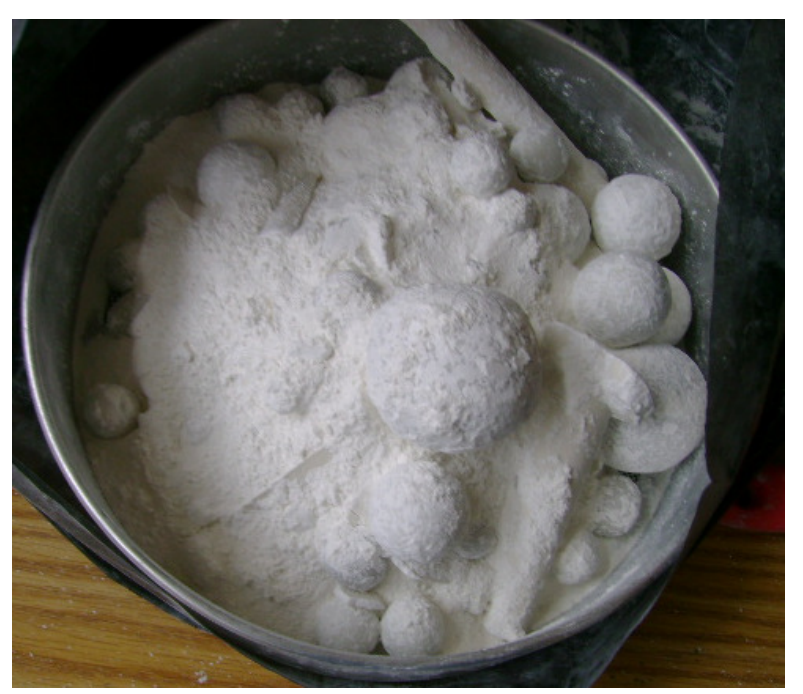

Figura 5.17 - Peneira com material após a moagem.

Dessa etapa de moagem foram obtidos $1050 \mathrm{~g}$ de pó de BMC posteriormente destinado à incorporação de uma formulação de PVC rígido. A idéia da escolha do PVC é justificada pelo fato desse material ser um composto e nessa condição o mesmo passa por um processo de preparação onde são colocados os diferentes componentes da formulação. Além disso, a resina de PVC também é em pó, com partículas de tamanho definido com porosidade, que favorece a mistura dos aditivos além de facilitar a incorporação com o pó de BMC. Uma justificativa para incorporação dos resíduos de BMC ao composto de PVC é a possibilidade de se preparar diferentes formulações e comparar com uma formulação convencional de que tenha alguma carga incorporada como, por exemplo, o carbonato de cálcio.

Foram realizadas moagens dos resíduos de BMC puro (sem verniz e sem metal) e de BMC com verniz e com metal para se conhecer a influência do 
metal e verniz nas propriedades dos resíduos. A Figura 5.18 ilustra partes de refletores metalizados preparados para moagem.

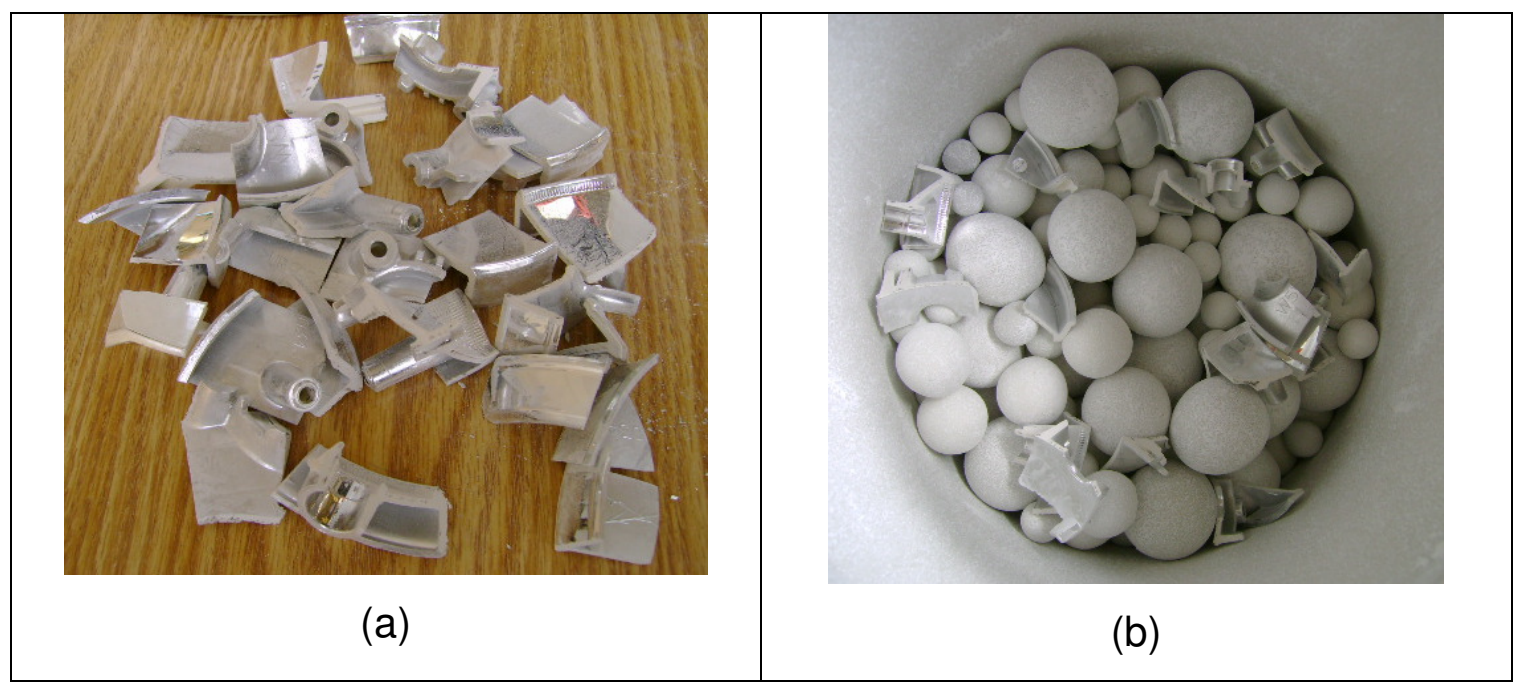

Figura 5.18 - Partes de refletores metalizados: a) Peças cortadas em serra de fita, b) Peças colocadas no moinho de bolas.

Além disso, em cada etapa de produção dos refletores em BMC é possível ocorrer problemas de qualidade das peças e essas serem destinadas aos aterros, porém, existem critérios para de separação dessas peças, ou seja, as peças metalizadas e com verniz são separadas das peças não metalizadas e sem verniz.

5.2.12 Determinação da distribuição de tamanho de partícula dos resíduos de BMC moído

Esse ensaio tem como objetivo determinar a distribuição de tamanho de partículas do BMC. O material analisado foi o resíduo de BMC após passar pelo processo de moagem e ser transformado num pó de granulometria consideravelmente reduzida. A amostra foi diluída em água e colocada numa câmara onde incide 0 feixe de raios $X$ (recurso imprescindível para 0 funcionamento do equipamento) que mudam de direção quando "colidem" com as partículas da amostra que é constantemente agitada, o desvio dos raios X, é monitorado e esse mecanismo permite a determinação da distribuição do 
tamanho das partículas. O ensaio foi realizado num equipamento LS Particle Size Analyzer modelo LS 100Q, conforme ilustrado na Figura 5.19.

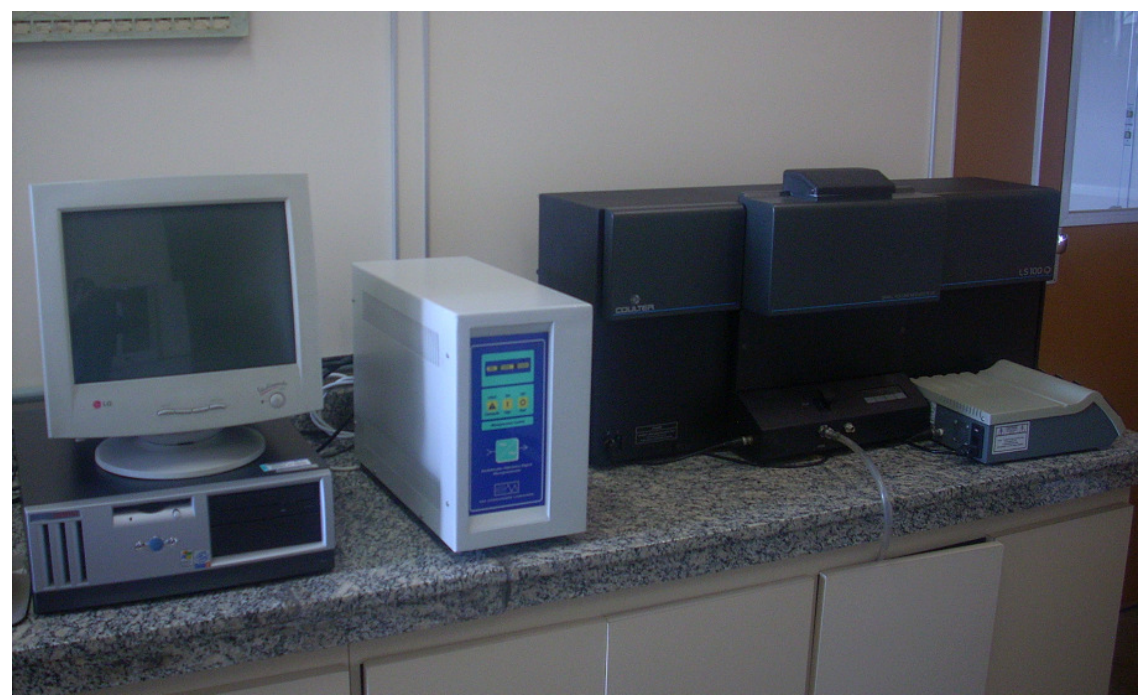

Figura 5.19 - Equipamento para determinação da distribuição do tamanho de partículas.

\subsubsection{Análise do BMC em pó via Infravermelho por transformada de} Fourier (FTIR)

O BMC conforme já descrito, é formado pela junção de diferentes substâncias, ou seja, é um compósito, portanto uma mistura heterogênea. Com o intuito de incorporar o resíduo de BMC ao PVC, fez-se necessário conhecer quais os grupos químicos presentes nesse material após a cura e demais etapas de processamento, pois os materiais separadamente são até conhecidos em termos de estrutura e propriedades, porém, depois do processamento não se conhece exatamente que tipo de estrutura e grupos químicos o resíduo de BMC poderá apresentar. A análise de espectroscopia do infravermelho é uma técnica baseada na espectroscopia de absorção que usa a região do infravermelho do espectro eletromagnético. Essa técnica permite identificar ou caracterizar uma determinada amostra, pois as ligações químicas entre os elementos que formam as substâncias possuem freqüências de vibrações específicas que possuem níveis de energia específicos. A amostra de BMC na forma de pó foi analisada num equipamento Nicolet Magna - IR 
550, conforme ilustrado na Figura 5.20. A amostra foi misturada com $\mathrm{KBr}$ seco, prensada até atingir o formato de pastilha. Adicionalmente, o material foi submetido à extração com a mistura acetona/clorofórmio nas proporções de $60 \%$ e $40 \%$ em volume respectivamente. A parte solúvel aplicada sobre um substrato de vidro e o filme resultante, após a evaporação do solvente também foram analisados. Os espectros obtidos foram comparados com os espectros da Hummel Polymer and Additives: Coating Technology.

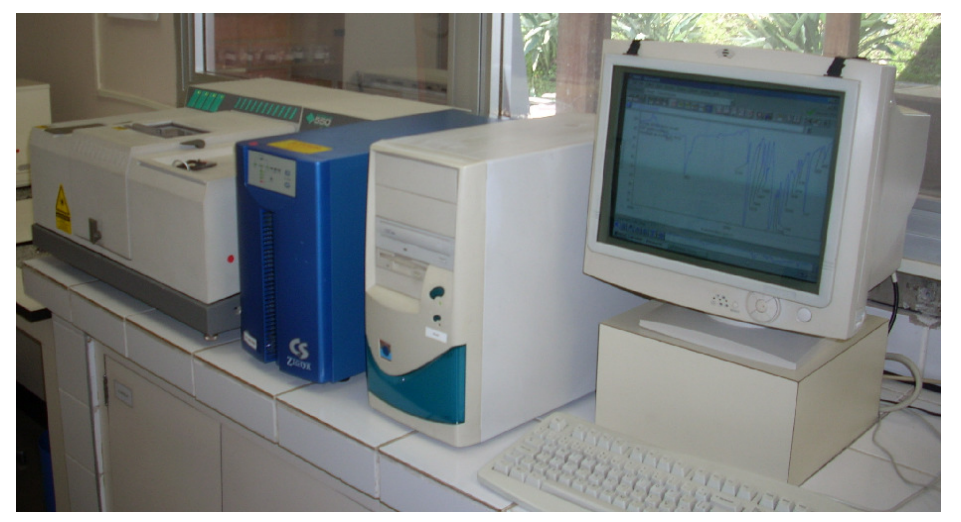

Figura 5.20 - Equipamento para análise por espectroscopia vibracional de infravermelho.

5.2.14 Incorporação do pó de BMC ao PVC e avaliação de propriedades

A incorporação do pó de BMC abordada no presente estudo envolveu diferentes etapas desde a mistura dos resíduos de BMC ao PVC até a obtenção dos corpos de prova. A Figura 5.21 ilustra as principais etapas desenvolvidas na incorporação dos resíduos de BMC ao composto de PVC rígido.

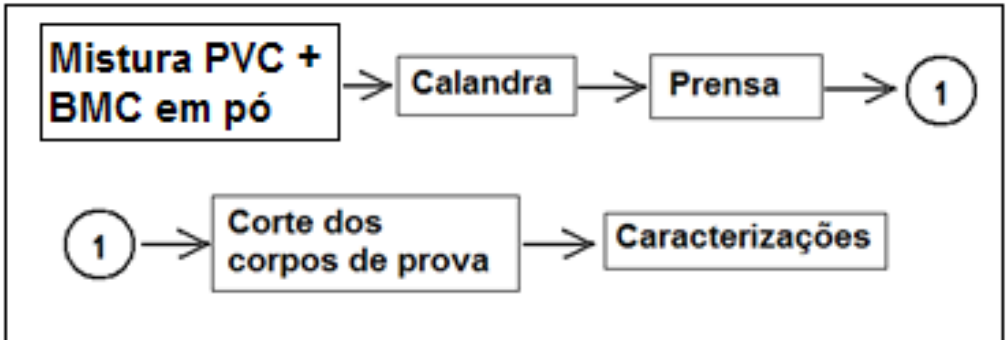

Figura 5.21 - Etapas de incorporação dos resíduos de BMC ao PVC. 
A homogeneização dos componentes presentes em cada formulação foi realizada num misturador Mecanoplast modelo ML 9, que é um equipamento normalmente utilizado para preparação de compostos de PVC, conforme ilustrado na Figura 5.22.

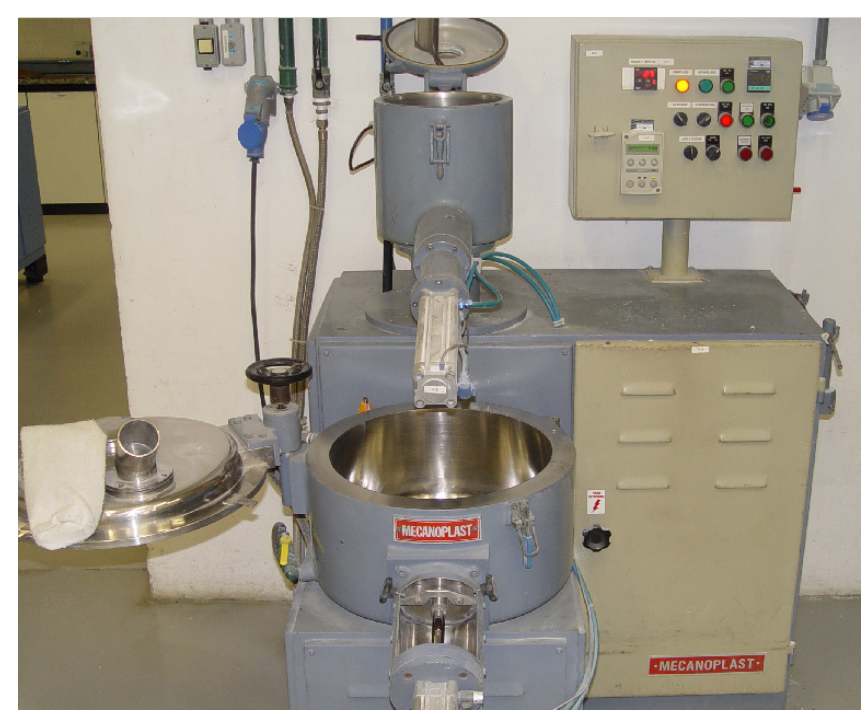

Figura 5.22 - Misturador para compostos de PVC.

Esse equipamento recebe todos os componentes em quantidades préestabelecidas de acordo com a formulação. A mistura ocorre com o movimento de uma hélice ilustrada na Figura 5.23, que em alta velocidade homogeneiza o composto e gera atrito entre o material e as partes internas do misturador que por sua vez irá aquecer para que haja melhor incorporação e interação entre os componentes da mistura. Se essa temperatura não for controlada, há risco de fusão ou até mesmo a degradação do composto.

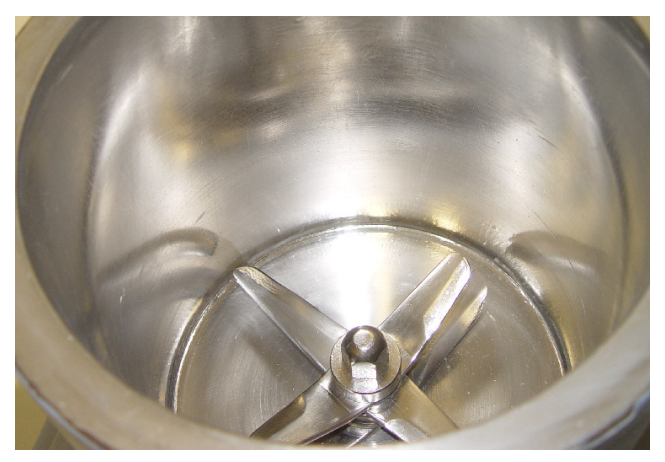

Figura 5.23 - Hélice do misturador de compostos de PVC. 
Para um melhor desempenho do equipamento e com o propósito de evitar possíveis contaminações do material o misturador é construído em aço inoxidável. A geometria das hélices força um material a gerar um fluxo da extremidade para o centro do misturador garantindo a melhor eficiência na mistura.

Com o objetivo de incorporar o BMC e realizar um comparativo de propriedades com outro material foram feitas 6 formulações diferentes de acordo com a Tabela 5.2.

Tabela 5.2 - Formulações de PVC em partes por cem de resina (PCR) para comparativos de propriedades.

\begin{tabular}{|c|c|c|c|c|c|c|}
\hline & $\begin{array}{c}\text { Formulação } \\
1\end{array}$ & $\begin{array}{c}\text { Formulaçäo } \\
2\end{array}$ & $\begin{array}{c}\text { Formulação } \\
3\end{array}$ & $\begin{array}{c}\text { Formulação } \\
4\end{array}$ & $\begin{array}{c}\text { Formulação } \\
5\end{array}$ & $\begin{array}{c}\text { Formulação } \\
6\end{array}$ \\
\hline $\begin{array}{l}\text { Resina } \\
\text { SP } 700 \mathrm{HF}\end{array}$ & 100 & 100 & 100 & 100 & 100 & 100 \\
\hline $\begin{array}{l}\text { Estabilizante } \\
\text { CZ } 1820\end{array}$ & 2,5 & 2,5 & 2,5 & 2,5 & 2,5 & 2,5 \\
\hline $\begin{array}{l}\text { Modif. de Fluxo } \\
\text { Polaroid K120 }\end{array}$ & 1,0 & 1,0 & 1,0 & 1,0 & 1,0 & 1,0 \\
\hline $\begin{array}{l}\mathrm{CaCO}_{3} \\
\text { Barralev C }\end{array}$ & 5,0 & - & - & 10,0 & - & - \\
\hline $\mathrm{BMC}$ & - & 5,0 & - & - & 10,0 & - \\
\hline $\mathrm{BMC}+$ metal & - & - & 5,0 & - & - & 10,0 \\
\hline
\end{tabular}

A resina de PVC SP $700 \mathrm{HF}$, produzida pela empresa Braskem é usada para compostos de PVC rígido e apresenta um valor $\mathrm{K}$ de 57 , que é um parâmetro que define indiretamente a massa molecular da resina. $O$ estabilizante térmico $C Z 1820$ é um aditivo à base de cálcio e zinco que tem por finalidade impedir ou retardar o processo de degradação do PVC. O modificador de fluxo K120 conforme sugere o nome, altera o fluxo do material no momento do processamento, diminuindo turbulências e reduzindo a taxa de cisalhamento do composto no momento do processamento. O BMC já foi descrito nesse mesmo capítulo.

A Tabela 5.2 apresenta 6 formulações com proporções fixas de resina de PVC, estabilizante térmico e modificador de fluxo, o que variou de uma 
formulação para outra foram os teores de carbonato de cálcio e de BMC. Às formulações 1 e 4 foi incorporado carbonato de cálcio nas proporções de 5 e de 10 PCR respectivamente, às formulações 2 e 5 o BMC puro com 5 e 10 PCR respectivamente e às formulações 3 e 6 com 5 e 10 PCR de BMC metalizado e com verniz. A comparação de propriedades foi realizada de acordo com as proporções de BMC colocadas no PVC, ou seja, as formulações com 5 PCR foram comparadas entre si assim como as formulações com 10 PCR. O rejeito de peças de BMC pode acontecer em diferentes momentos do processo, esse fato justifica a comparação dos resíduos de BMC com e sem a metalização com alumínio com a camada de verniz.

Os parâmetros do misturador foram os seguintes: 2800 RPM de velocidade das hélices até a mistura atingir $120{ }^{\circ} \mathrm{C}$. A mistura foi conduzida para um resfriador até atingir $40{ }^{\circ} \mathrm{C}$. Cada uma das formulações seguiu $\mathrm{O}$ mesmo critério permanecendo após o processo de mistura por um período de $24 \mathrm{~h}$ a $23{ }^{\circ} \mathrm{C}$ para melhor interação entre os componentes da formulação. Passado o período de condicionamento as misturas foram conduzidas para a etapa de preparação de placas para confecção dos corpos de prova. Inicialmente as misturas passaram por uma calandra, conforme ilustra a Figura 5.24, que recebe o material em pó e o transforma numa massa fundida. Os parâmetros de processo da calandra foram os seguintes: 25 RPM a $190{ }^{\circ} \mathrm{C}$ por 3 minutos.

Quando a massa saiu da calandra a mesma foi conduzida a uma prensa, conforme ilustrado na Figura 5.25 para formar as placas que foram posteriormente cortadas para obtenção dos corpos de prova. Os parâmetros da prensa foram os seguintes: temperatura de $175{ }^{\circ} \mathrm{C}$ e pressão de $100 \mathrm{kgf.cm}^{-2}$ durante $3 \mathrm{~min}$, após esse tempo a pressão foi aumentada para $200 \mathrm{kgf.cm}^{-2}$ por um período de $1 \mathrm{~min}$. Após esse período foi desligado o aquecimento e acionado o resfriamento das placas até que as mesmas atingissem $40^{\circ} \mathrm{C}$. Após essa etapa as placas moldadas foram extraídas. 


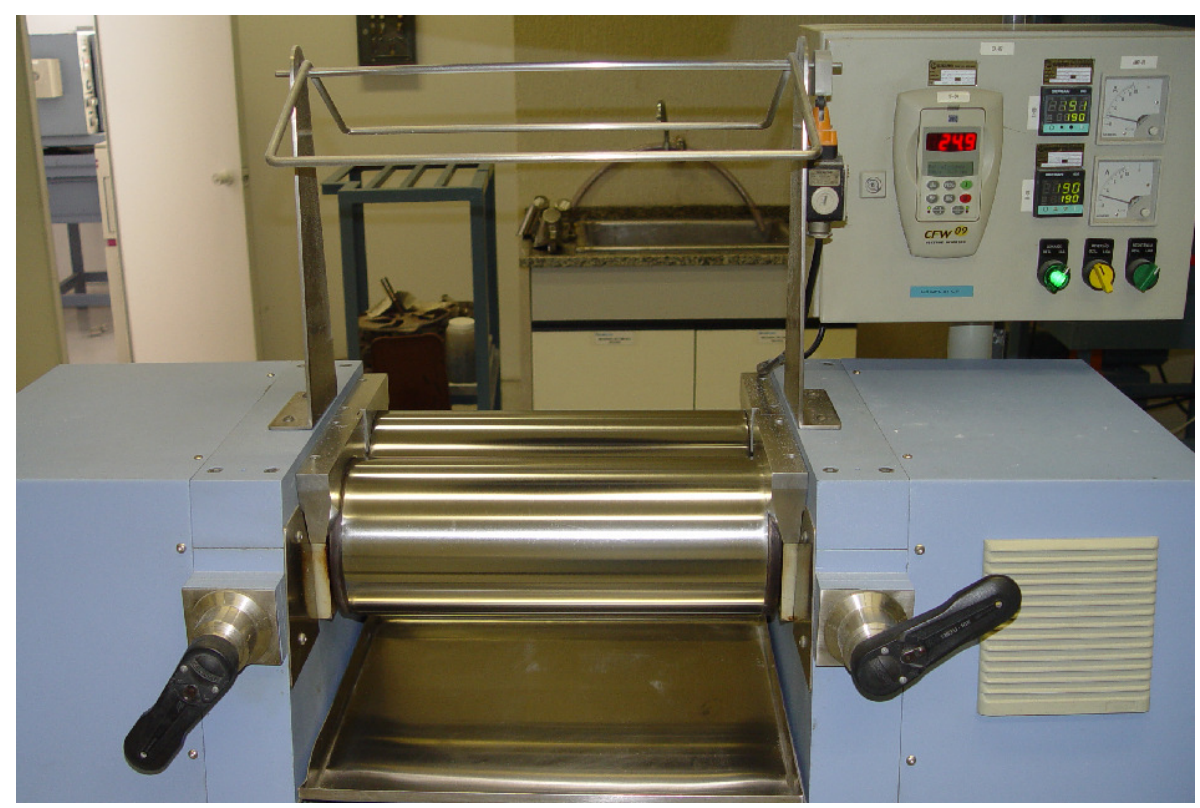

Figura 5.24 - Calandra para processamento de compostos ou misturas de PVC.

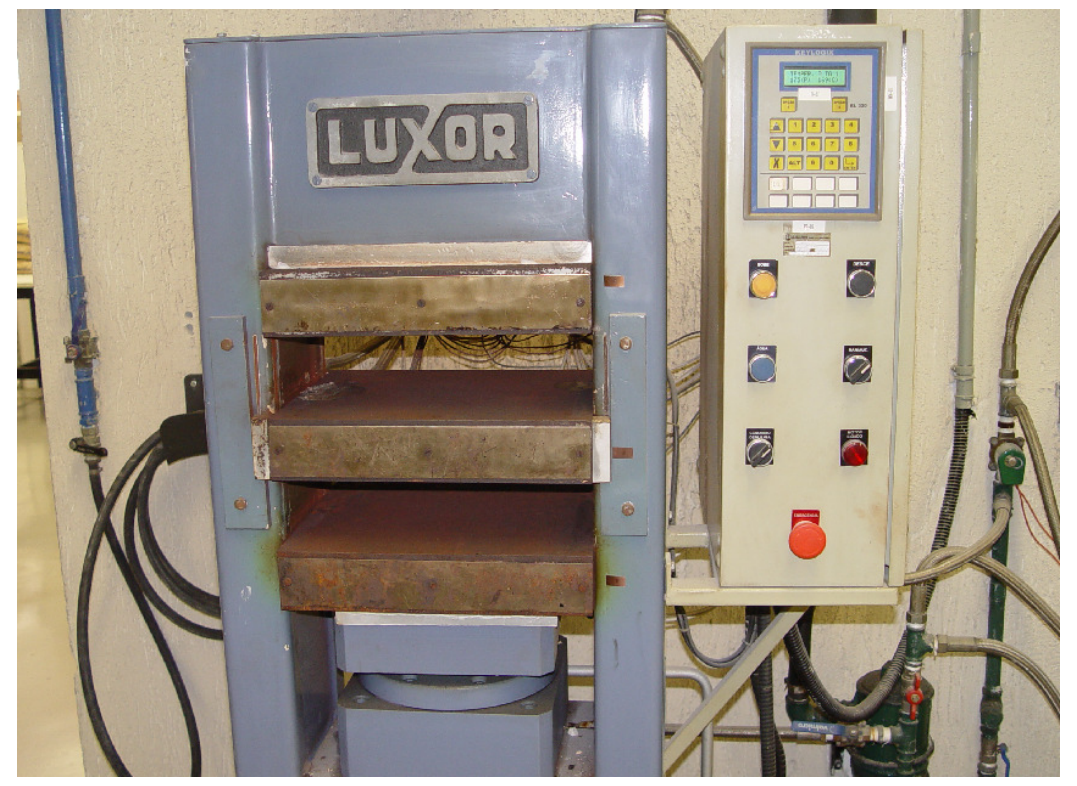

Figura 5.25 - Prensa para processamento de compostos ou misturas de PVC.

Quando as placas de PVC estavam prontas, foram cortados corpos de provas de acordo as normas escolhidas para as possíveis caracterizações. 
Com o intuito de se avaliar a influência do BMC incorporado ao PVC foram realizados outros ensaios mais comumente empregados na caracterização dos compostos de PVC.

5.2.14.1 Determinação da resistência à tração do composto de PVC com diferentes teores de BMC.

Os ensaios das 6 formulações foram realizados em corpos de prova de acordo com a norma ASTM D 638 numa máquina universal de ensaios MTS modelo Alliance RT/5, conforme ilustrado na Figura 5.26.

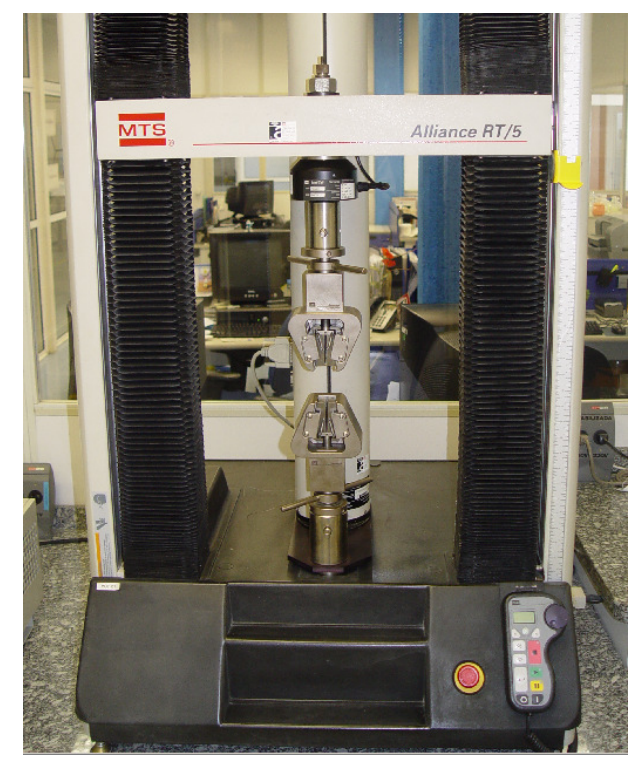

Figura 5.26 - Máquina universal de ensaios mecânicos.

5.2.14.2 Determinação da resistência ao impacto do composto de PVC com diferentes teores de BMC.

Os ensaios para determinação da resistência ao impacto foram realizados segundo a norma ASTM DE 256 em corpos de prova tipo Charpy, com martelo de $1 \mathrm{~J}$, num equipamento modelo Ceast Resil 5.5 e os corpos de prova entalhados num entalhador modelo Ceast Notchvis ilustrados nas Figuras 5.27 a e $5.27 b$, respectivamente. 


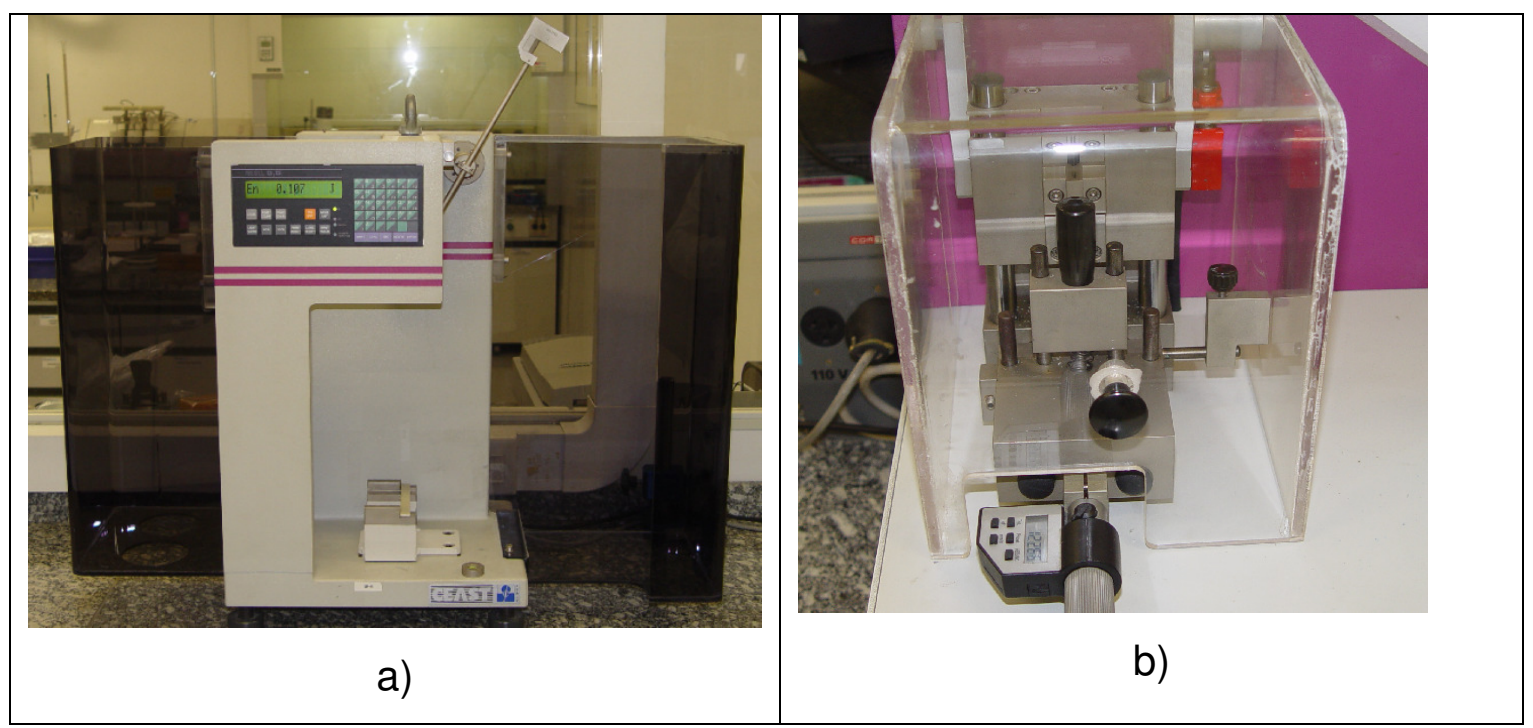

Figura 5.27 - Análise de resistência ao impacto: a) aparelho, b) entalhador de corpos de prova.

5.2.14.3 Determinação da temperatura de amolecimento Vicat do composto de PVC com diferentes teores de BMC.

O ensaio para determinação da temperatura de amolecimento Vicat foi realizado segundo a norma ASTM D 1525 num equipamento, ilustrado anteriormente na Figura 5.12.

5.2.14.4 Determinação dos pontos de gelificação, fusão e degradação térmica do composto de PVC com diferentes teores de BMC.

Os ensaios de gelificação e fusão foram realizados num reômetro de torque marca Haake, conforme ilustrado na Figura 5.28 [Ormanji et. al, 2002]. Foram utilizados 65 gramas de material para cada formulação, velocidade constante de 40 RPM e temperatura de $140{ }^{\circ} \mathrm{C}$. O termo gelificação ou gelação se refere a uma condição que antecede a fusão do composto no momento do processamento. A resina obtida pela polimerização por suspensão apresenta partículas de superfície ligeiramente irregulares conforme ilustrado na Figura 5.26a, na Figura 5.26b observa-se a imagem de um composto (imagens obtidas por microscopia eletrônica de varredura). Quando o composto é processado o mesmo sofre cisalhamento e aquecimento simultâneos, que proporcionam fluxo caracterizado pela movimentação de partículas e também 
fluxo molecular deformacional. A importância desse ensaio está no fato de fornecer informações importantes para o processamento do composto como, por exemplo, tempo de fusão e torque.

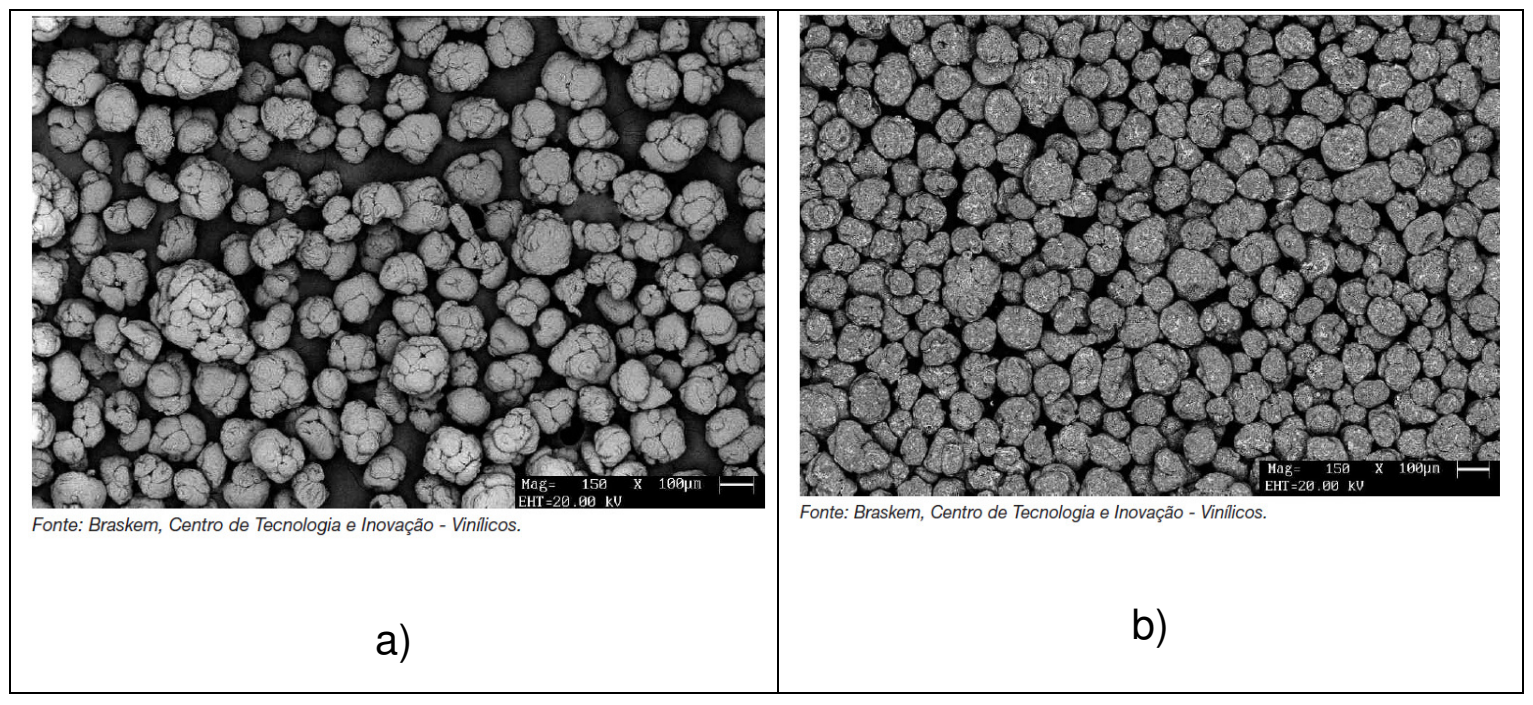

Figura 5.28 - Micrografia eletrônica da varredura: a) resina de PVC polimerizada por suspensão, b) resina de PVC misturada com aditivos [Ormanji et. al, 2002].

A reômetro de torque é um equipamento constituído por uma câmara aquecida onde existem rotores de geometria adequada que giram de forma contra rotacional, conforme ilustrado na Figura 5.29a, na Figura 5.29b é ilustrado o equipamento fechado. No decorrer do ensaio é monitorado o torque necessário para movimentação dos rotores, a uma velocidade fixa, a energia consumida e temperatura da massa no interior da câmara.

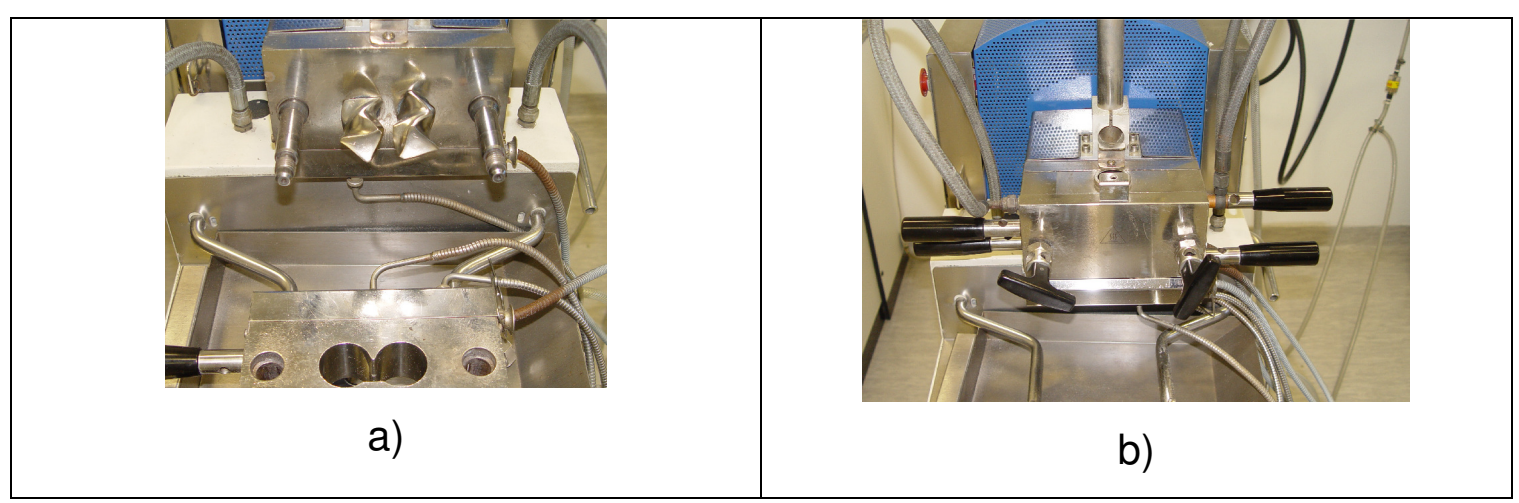

5.29 - Reômetro de torque: a) câmara de aquecimento aberta, b) câmara de aquecimento fechada 


\section{RESULTADOS E DISCUSSÃO}

\subsection{Ensaio de resistência à tração}

Um importante recurso para os ensaios de determinação da resistência àtração é o gráfico tensão versus deformação, ilustrado na Figura 6.1 e Figura 6.2, respectivamente para o $\mathrm{BMC}$ e para o $\mathrm{PEI}$. Os ensaios foram realizados segundo a norma ISO 527, adotando-se velocidade de $5 \mathrm{~mm} \cdot \mathrm{min}^{-1}$ para os dois materiais.

Fica evidente pelos gráficos que o BMC é um material muito mais rígido e como conseqüência apresenta uma capacidade de deformação inferior ao PEI. A maior rigidez do BMC é atribuída aos reforços fibrosos. O BMC apresenta uma deformação de apenas $0,83 \%$ contra $7,74 \%$ do PEI e respectivamente módulos de elasticidade de 6254 e $2347 \mathrm{MPa}$. O maior desvio associado ao BMC é resultado deste material apresentar uma heterogeneidade maior que a do $\mathrm{PEI}$, uma vez que este último pode ser considerado um material isotrópico.

\section{Tensão (MPa)}

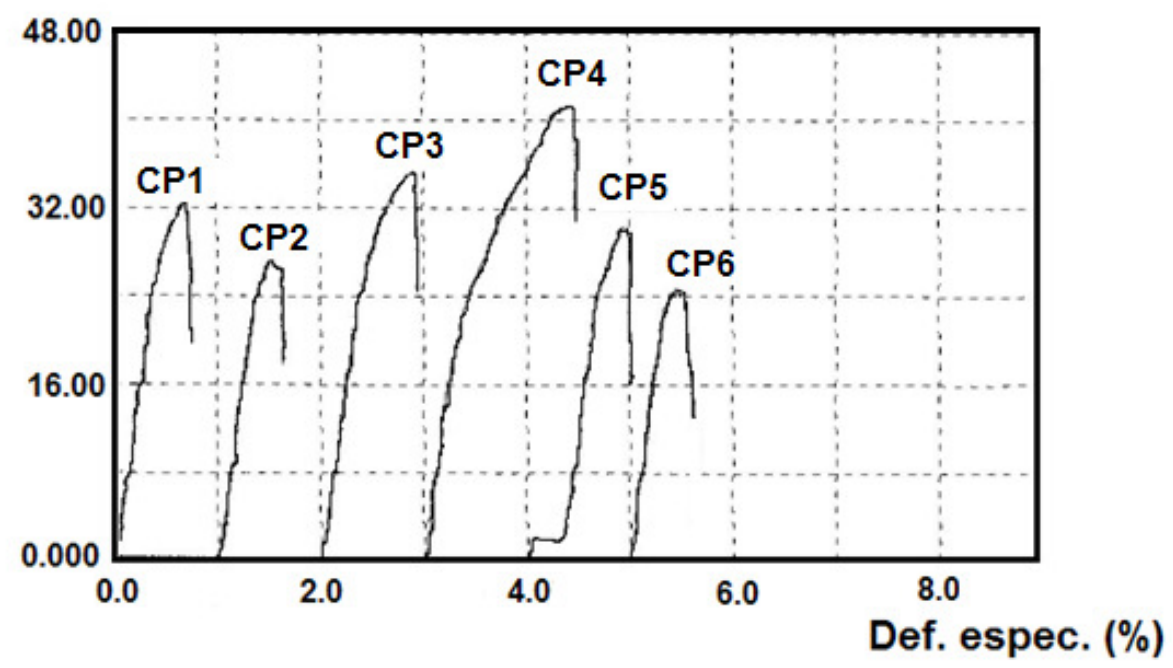

Figura 6.1 - Gráfico tensão versus deformação para o BMC. 


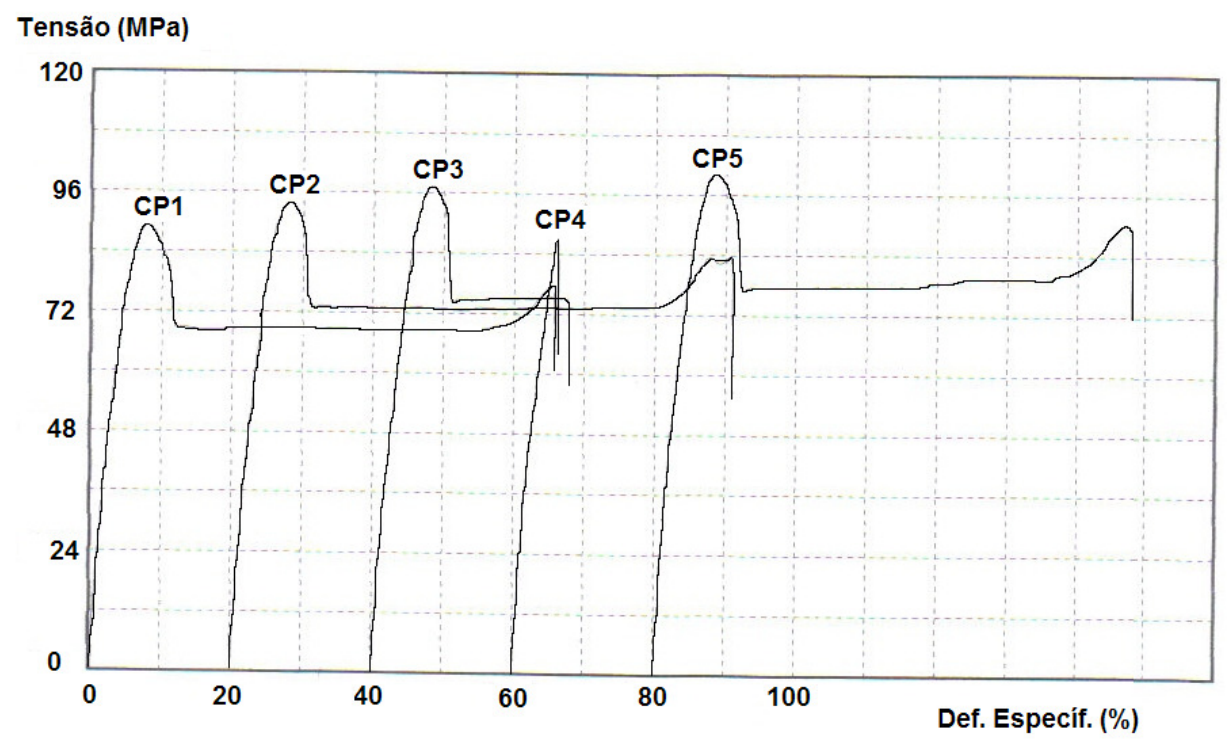

Figura 6.2 - Gráfico tensão versus deformação para o PEI.

A Tabela 6.1 mostra os resultados dos ensaios de tração É possível identificar que o PEI apresenta uma resistência à tração cerca de duas vezes àquela do BMC. Entretanto, por apresentar uma deformação muito maior, mostra módulo de elasticidade que é a metade daquele do BMC. A maior resistência do $\mathrm{PEI}$ favorece a montagem do refletor que pode sofrer esforços de tração nessa etapa do trabalho, por esse motivo é muito importante saber o quanto esses materiais suportam.

Tabela 6.1 - Valores médios do ensaio de resistência à tração BMC e do PEI.

\begin{tabular}{ccccc}
\hline & BMC & $\begin{array}{c}\text { Desvio } \\
\text { padrão BMC }\end{array}$ & PEI & $\begin{array}{c}\text { Desvio } \\
\text { padrão PEI }\end{array}$ \\
\hline $\begin{array}{c}\text { Tensão força } \\
\text { máxima (N) }\end{array}$ & 32 & 6 & 93 & 5 \\
$\begin{array}{c}\text { Tensão de } \\
\text { ruptura (MPa) } \\
\text { Deformação }\end{array}$ & 29 & 8 & 83 & 7 \\
$\begin{array}{c}\text { específica (\%) } \\
\text { Deformação de } \\
\text { ruptura (\%) } \\
\text { Módulo de } \\
\text { elasticidade } \\
\text { (MPa) }\end{array}$ & 0,8 & 0,4 & 7,7 & 0,9 \\
\hline
\end{tabular}

A Figura 6.3a ilustra um importante comparativo envolvendo a resistência à tração do $\mathrm{BMC}$ e a do $\mathrm{PEI}$, onde é possível a identificar a maior tensão de ruptura para o PEI quando submetido a esforços de tração. Apesar 
das diferenças de valores verificadas, deve-se considerar que 0 comportamento mecânico desses é bastante diferente porque o PEI pode se deformar consideravelmente, enquanto que no BMC a deformação é mínima. A Figura 6.3b ilustra as diferenças de deformação dos dois materiais. Essa propriedade é importante de ser avaliada pelo fato dessas peças serem submetidas a esforços mecânicos durante a montagem e também quando em campo.

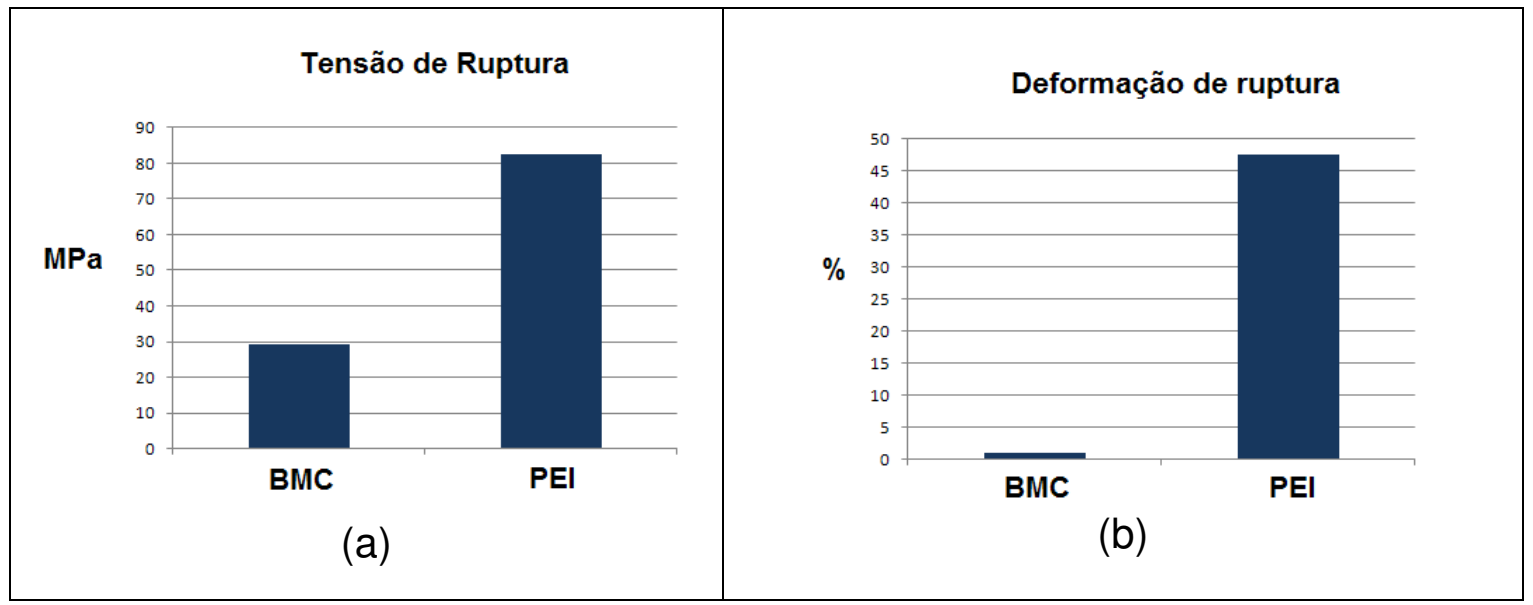

Figura 6.3: a) tensão de ruptura do BMC e do PEI, b) deformação do BMC e do PEl quando submetidos à tração.

Os corpos de prova de PEl ilustrados na Figura 6.4a e Figura 6.4b permitem comparar a deformação antes e depois, respectivamente. No detalhe da Figura $6.4 \mathrm{~b}$ é possível notar o modo de falha do material no ensaio de tração.

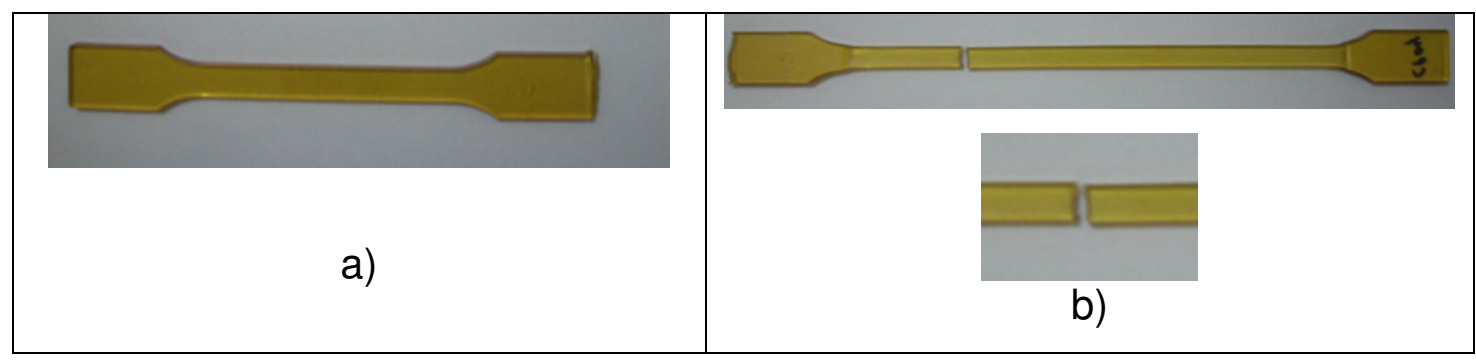

Figura 6.4: a) corpo de prova de PEI para ensaio para caracterização mecânica antes do ensaio, b) após o ensaio com detalhes da ruptura 
Muitos materiais termoplásticos têm capacidade de se deformar quando submetido a um esforço de tração pelo fato de suas macromoléculas deslizarem umas sobre as outras.

No caso dos corpos de prova de BMC, ilustrados na Figura 6.5a e 6.5b, é possível a visualização do corpo de prova após o ensaio e a deformação foi muito menor uma vez que esse material apresenta um comportamento tipicamente elástico (fratura frágil), enquanto que o PEI mostra um comportamento nitidamente plástico, com uma grande deformação antes da ruptura.

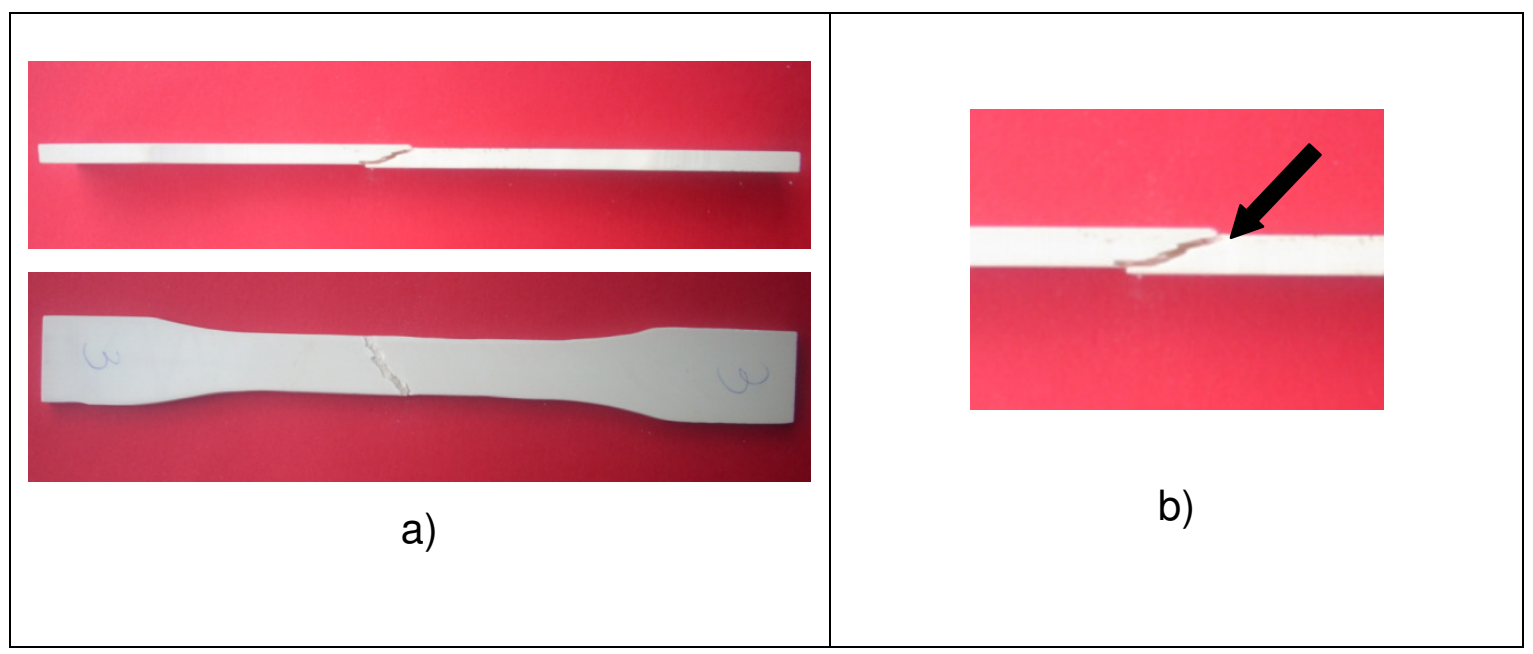

Figura 6.5 - Corpos de prova de BMC após o ensaio para caracterização mecânica: a) geometria do corpo de prova, b) vista de perfil lateral mostrando detalhe da fratura.

O tipo de fratura observado pode ser atribuído ao fato de o material ser uma mistura de diferentes substâncias que se interagem e o polímero desse compósito é um material termofixo, que tem a estrutura caracterizada por ligações cruzadas, fator que impede o deslizamento entre moléculas quando submetidas a um determinado esforço. No caso desse material, a interface entre as fibras e o polímero termofixo, também impede que esse se deforme significativamente, fato que pode ser confrontado com os valores expressos na Tabela 6.1. 


\subsection{Ensaios térmicos}

6.2.1 Determinação da temperatura de deflexão térmica (HDT)

O ensaio para determinação da temperatura de deflexão térmica (HDT) é um dos mais importantes na comparação das propriedades térmicas entre 0 BMC e o PEI. A Tabela 6.2 registra os valores relativos ao ensaio de HDT para o BMC e para o PEI. De acordo com as dimensões do corpo de prova, o ensaio para o BMC deveria ser interrompido quando a deflexão atingisse $0,33 \mathrm{~mm}$ conforme a norma ISO 75, porém houve necessidade de se interromper 0 ensaio muito antes desse deslocamento ser atingido porque com 0 deslocamento de apenas $0,03 \mathrm{~mm}$ o equipamento já havia atingido $265,8^{\circ} \mathrm{C}$. $\mathrm{O}$ limite máximo de aquecimento do equipamento que trabalha com óleo de silicone é de $280{ }^{\circ} \mathrm{C}$ e baseado na pouca deformação do BMC o ensaio foi paralisado nas condições já informadas enquanto o PEI com temperaturas entre 184,1 e 185,3 ${ }^{\circ} \mathrm{C}$ deformou 0,32 mm. Com esses valores pode-se observar que a resistência térmica do BMC é muito superior à resistência térmica do PEI o que torna o BMC indicado para aplicação em refletores que o PEI.

Tabela 6.2 - Determinação da temperatura de deflexão térmica (HDT) do $\mathrm{BMC}$ e do PEI.

\begin{tabular}{ccccccc}
\hline & \multicolumn{3}{c}{ BMC } & \multicolumn{3}{c}{ PEI } \\
\hline & $\begin{array}{c}\text { Corpo } \\
\text { de } \\
\text { prova 1 }\end{array}$ & $\begin{array}{c}\text { Corpo } \\
\text { de } \\
\text { prova 2 }\end{array}$ & $\begin{array}{c}\text { Corpo } \\
\text { de } \\
\text { prova 3 }\end{array}$ & $\begin{array}{c}\text { Corpo } \\
\text { de } \\
\text { prova 1 }\end{array}$ & $\begin{array}{c}\text { Corpo } \\
\text { de } \\
\text { prova 2 }\end{array}$ & $\begin{array}{c}\text { Corpo } \\
\text { de } \\
\text { prova 3 }\end{array}$ \\
\hline Tensão $(\mathrm{kPa})$ & 1800 & 1800 & 1800 & 1800 & 1800 & 1800 \\
Carga aplicada $(\mathrm{g})$ & 1229 & 1212 & 1068 & 872 & 872 & 872 \\
$\begin{array}{c}\text { Final do teste }(\mathrm{mm}) \\
\begin{array}{c}\text { Final da deflexão } \\
\text { (mm) }\end{array}\end{array}$ & 0,33 & 0,33 & 0,33 & 0,32 & 0,32 & 0,32 \\
$\begin{array}{c}\text { Temperatura }\left({ }^{\circ} \mathrm{C}\right) \\
\text { de deflexão }\end{array}$ & 265,8 & 0,03 & 0,05 & 0,32 & 0,32 & 0,32 \\
\hline
\end{tabular}


Com base na Figura 6.6 pode-se observar que a resistência térmica do $\mathrm{BMC}$ é superior à resistência térmica do PEI e essa é uma propriedade importante para o desempenho de um refletor para farol de automóvel. A mínima deformação do refletor terá como inconveniente desvio nos raios de luz provenientes da lâmpada e essa condição deve ser evitada, pois a má iluminação pode comprometer a segurança das pessoas que trafegam pela via.

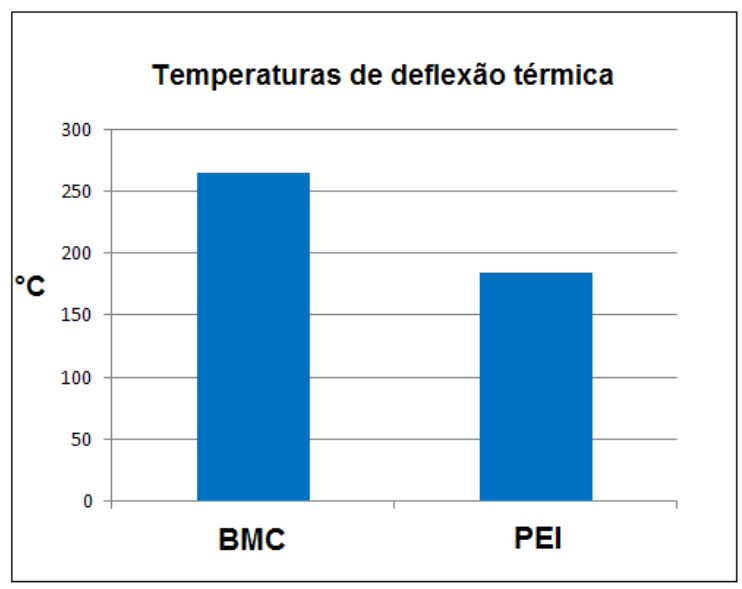

Figura 6.6 - Comparativo dos valores médios de HDT para o BMC e para o PEI.

\subsubsection{Determinação da temperatura de amolecimento Vicat do BMC}

Em função dos resultados encontrados no ensaio de HDT para o BMC não foi realizado o ensaio de determinação da temperatura de amolecimento Vicat para o BMC, pois se à temperatura de $266,2{ }^{\circ} \mathrm{C}$ o material sob carga deformou apenas $0,03 \mathrm{~mm}$ muito provavelmente esse material não iria ser penetrado em $1 \mathrm{~mm}$ por uma agulha com área de $1 \mathrm{~mm}^{2}$, conforme a norma ISO 306. Como o ensaio de temperatura de amolecimento Vicat é realizado no mesmo equipamento que realiza o ensaio de HDT o limite de aquecimento máximo do equipamento é o mesmo.

Equipamentos que possuem maior capacidade de aquecimento para realização do ensaio para determinação da temperatura de amolecimento Vicat, quando realizam esse ensaio não conseguem amolecer o material para que a agulha penetre $1 \mathrm{~mm}$. Essa condição demonstra a resistência térmica das peças confeccionadas com o BMC. 
Tabela 6.3 - Determinação da temperatura de amolecimento Vicat do PEI.

\begin{tabular}{|c|c|c|c|}
\hline & Estação 1 & Estação 2 & Estação 3 \\
\hline & $\begin{array}{l}\text { Corpo de } \\
\text { prova } 1\end{array}$ & $\begin{array}{l}\text { Corpo de } \\
\text { prova } 2\end{array}$ & $\begin{array}{l}\text { Corpo de } \\
\text { prova } 3\end{array}$ \\
\hline Carga aplicada $(\mathrm{N})$ & 50 & 50 & 50 \\
\hline Final do teste (mm) & 1 & 1 & 1 \\
\hline Final da deflexão $(\mathrm{mm})$ & 1 & 1 & 1 \\
\hline $\begin{array}{l}\text { Temperatura de } \\
\text { amolecimento }\left({ }^{\circ} \mathrm{C}\right)\end{array}$ & 198,3 & 198,8 & 199,6 \\
\hline
\end{tabular}

Comparando os valores de HDT e Vicat do PEl é possível perceber que no segundo ensaio os valores de temperaturas são maiores, o que é mais uma justificativa para a não realização do ensaio de determinação de temperatura de amolecimento Vicat para o BMC.

\subsubsection{Ensaio de DSC}

O ensaio de DSC - calorimetria exploratória de varredura foi realizado apenas para o PEI porque não se aplica a materiais termofixos. O pico de apresentado no gráfico representa a temperatura de transição vítrea $(\mathrm{Tg})$ do PEI. Abaixo dessa temperatura as macromoléculas da fase amorfa, predominantes nesse material, estão imobilizadas e o polímero é rígido. Esse valor é importante porque apresenta o comportamento térmico do material quando submetido a uma taxa controlada de aumento de temperatura, principalmente pelo fato da temperatura da região próxima ao refletor atingir valores próximos aos $200{ }^{\circ} \mathrm{C}$ e o refletor suportar sem sofrer deformações mesmo que momentâneas que comprometam o comportamento adequado do farol. 


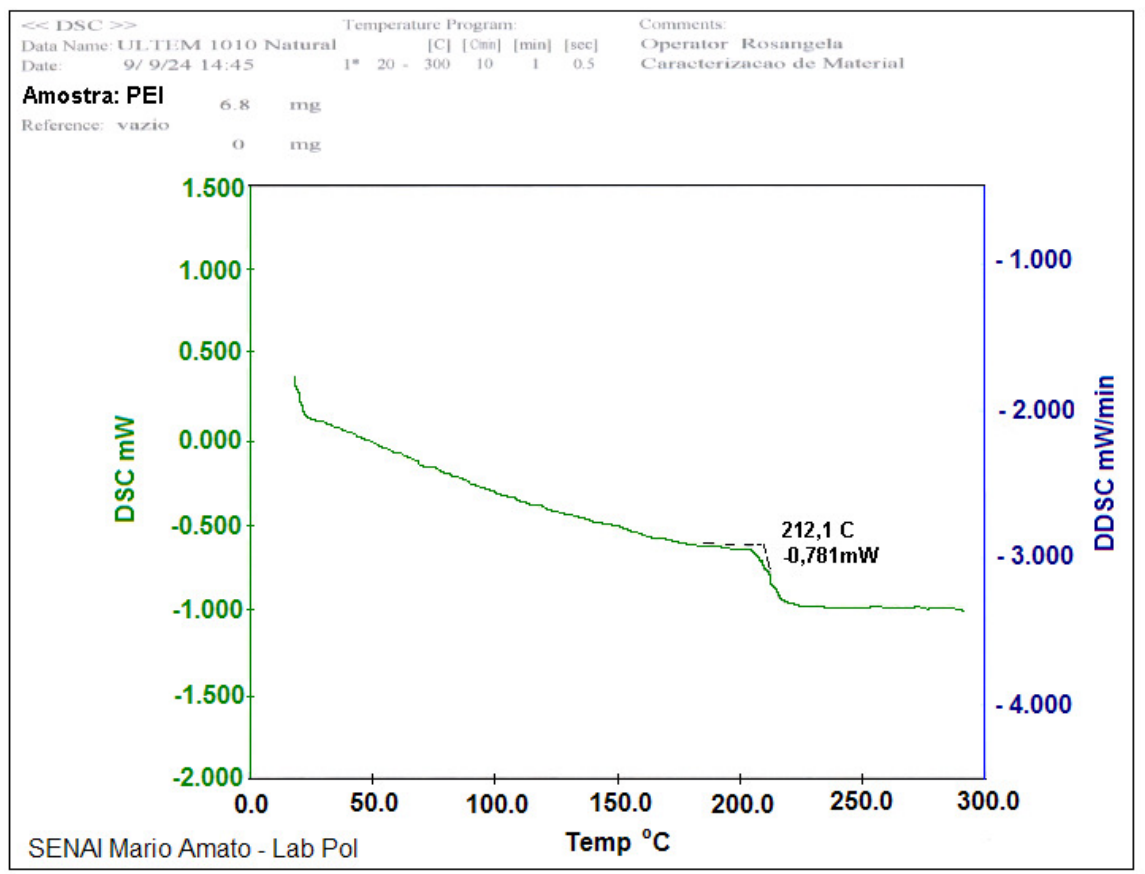

\subsection{Calcinação}

Este ensaio, conforme a norma ASTM D 297, foi realizado apenas para o BMC porque o PEI não é um material compósito. Nas amostras analisadas o valor médio do teor em massa de fibra de vidro das amostras 1 e 2 ficou em $53 \%$ e o desvio padrão de $\pm 0,95$. As proporções de reforço são fundamentais para as propriedades mecânicas de um compósito. Há projetos que tem como requisito frações elevadas do elemento de reforço, que podem chegar a $65 \%$. Outros, no entanto, apresentam proporções do reforço bem baixas, em torno de $20 \%$.

Tabela 6.4 - Cálculos do teor de fibra de vidro - Amostras 01 e 02.

\begin{tabular}{lcc}
\hline & Amostra 01 & Amostra 02 \\
\hline Cadinho vazio & $40,39 \mathrm{~g}$ & $39,87 \mathrm{~g}$ \\
Cadinho + amostra & $47,93 \mathrm{~g}$ & $47,43 \mathrm{~g}$ \\
Massa da amostra & $7,54 \mathrm{~g}$ & $7,57 \mathrm{~g}$ \\
$\begin{array}{l}\text { Cadinho após a } \\
\text { queima }\end{array}$ & $44,31 \mathrm{~g}$ & $43,91 \mathrm{~g}$ \\
$\begin{array}{l}\text { Cálculo do teor de } \\
\text { fibra de vidro }\end{array}$ & {$[(44,31-40,39) / 7,54] 100$} & {$[(43,41-39,87) / 7,57] 100$} \\
$\begin{array}{l}\text { Teor de fibra de vidro } \\
\text { (em massa) }\end{array}$ & $52 \%$ & $53 \%$ \\
\hline
\end{tabular}


Os gráficos presentes na Figura 6.7 permitem a visualização das frações mássiicas que compõem a formulação de BMC usada para confecção dos refletores. O BMC é um material compósito, portanto suas propriedades dependem da interação do material polimérico com o reforço, no caso, a fibra de vidro. A fibra de vidro apresenta propriedades muito superiores aos polímeros, como, por exemplo, resistência à tração e ponto de fusão. Quando um compósito é feito, as propriedades do componente matricial e estrutural são conjugadas, ou seja, polímero e fibra de vidro se interagem de modo a produzir um material bastante resistente. A determinação do teor de fibra de vidro é importante, para de se conhecer melhor as propriedades dos compósitos. A melhor resistência térmica e do BMC só é justificada pelo fato de esse material ser um compósito termofixo, portanto os valores de $52 \%$ e de $53 \%$ são muito importantes no desempenho dos refletores.

Esse ensaio não foi realizado para o PEI pelo fato de esse material não ser um compósito.

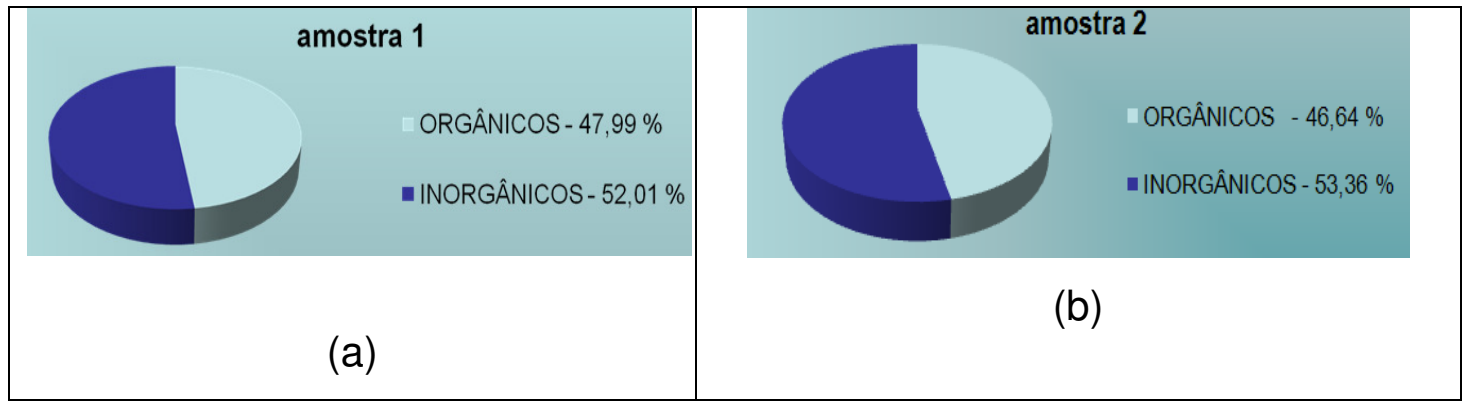

Figura 6.7 Ensaio de calcinação do BMC: a) amostra 1, b) amostra 2.

6.4 Análise quantitativa por espectrometria de fluorescência de raios $\mathrm{X}$

As substâncias encontradas no resíduo de calcinação podem ser explicadas porque conforme citado anteriormente o BMC é um compósito formulado com diferentes materiais que possuem diferentes funções objetivando atingir as propriedades requeridas de acordo com a aplicação. $O$ conhecimento dessas substâncias é importante não apenas pelas propriedades do material, mas também para o caso de uma possível aplicação ou utilização desses resíduos. A Tabela 6.5 apresenta as substâncias presentes nos resíduos de calcinação do BMC. Numa possível incineração do BMC, são 
essas substâncias que não irão entrar em combustão e, portanto, irão sobrar como resíduo.

Tabela 6.5 - Teores de substâncias inorgânicas encontradas nos resíduos de calcinação do BMC.

\begin{tabular}{cc|cc}
\hline Substâncias & Resultados (\%) & Substâncias & Resultados (\%) \\
\hline Perda ao fogo & 16,54 & $\mathrm{MgO}$ & 0,84 \\
\hline $\mathrm{SiO}_{2}$ & 24,64 & $\mathrm{Na}_{2} \mathrm{O}$ & 0,06 \\
\hline $\mathrm{Al}_{2} \mathrm{O}_{3}$ & 6,26 & $\mathrm{~K}_{2} \mathrm{O}$ & 0,03 \\
\hline $\mathrm{Fe}_{2} \mathrm{O}_{3}$ & 0,08 & $\mathrm{MnO}$ & $<0,001$ \\
\hline $\mathrm{TiO}_{2}$ & 0,26 & $\mathrm{P}_{2} \mathrm{O}_{5}$ & 0,12 \\
\hline $\mathrm{CaO}$ & 51,11 & & \\
\hline
\end{tabular}

6.5 Análise por termogravimetria - TGA

O ensaio por TGA realizado na amostra de BMC pode detectar em que temperatura esse material começa a ter significativa perda de massa, além da sobra do teor de inorgânicos presentes. A Figura 6.8 ilustra os valores por meio de um gráfico gerado a partir da análise de TGA realizada numa amostra de BMC.

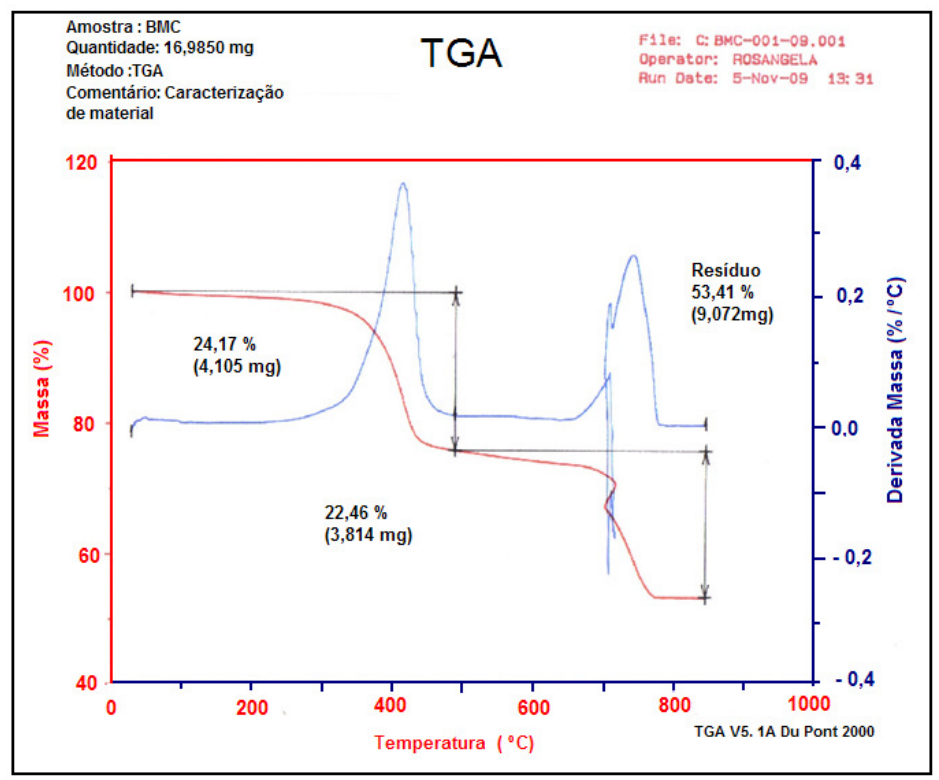

Figura 6.8 - Análise da perda de massa utilizando a curva termogravimétrica. 
A partir do ensaio de TGA do BMC, nota-se que há uma perda acentuada de massa a partir dos $300{ }^{\circ} \mathrm{C}$ e outra perda de massa a partir dos $700{ }^{\circ} \mathrm{C}$ restando $53,41 \%$ da massa inicial da amostra de BMC, que é referente aos componentes inorgânicos. A Figura 6.8 apresenta duas curvas sendo a primeira relativa à perda de massa em função da temperatura (linha vermelha) e a segunda ilustra a derivada da perda de massa em função da temperatura (linha azul). Apesar das duas curvas representarem o mesmo fenômeno elas se complementam o que é fundamental quando a definição na curva referente à perda de massa não é satisfatória.

Um material com baixa resistência térmica teria uma perda de massa significativa numa temperatura muito menor, como por exemplo, o PVC é termoplástico que sofre acentuada perda de massa a $250{ }^{\circ} \mathrm{C}$.

\subsection{Informações do processo produtivo}

Os refletores confeccionados em BMC envolvem um número de etapas muito superior ao do PEl. Essas são divididas em preparação da massa, transporte, armazenamento em temperaturas de 10 a $14{ }^{\circ} \mathrm{C}$, injeção dos refletores, lavagem e secagem, aplicação de uma camada de verniz, metalização, aplicação de outra camada de verniz. A fabricação dos refletores em PEI envolve a secagem dos grânulos, injeção, metalização e aplicação da camada de verniz. Considerando-se todas as etapas de processo dos refletores para ambos os materiais aproximadamente $15 \%$ das peças são rejeitadas enquanto para os refletores confeccionados em PEI esse número é inferior a $5 \%$.

\subsection{Reaproveitamento de resíduos}

Uma das opções verificadas é a reciclagem ou reutilização dos materiais a partir dos resíduos gerados tanto do PEI quanto do BMC. O PEI conforme abordado anteriormente é um material termoplástico, portanto, pode ser reprocessado, e isso acontece na prática, pois as sobras e aparas geradas durante o processo podem ser trituradas e fundidas novamente, mas o BMC, pelo fato de ser um compósito termofixo não pode ser reprocessado, por esse 
motivo foi estudada uma possibilidade de reaproveitamento a partir da transformação do resíduo sólido em pó, para incorporação numa outra matriz polimérica. A Figura 6.10a ilustra aparas e peças de BMC, oriundos do processo de fabricação dos refletores e a Figura 6.10b ilustra o material colocado no moinho de bolas.

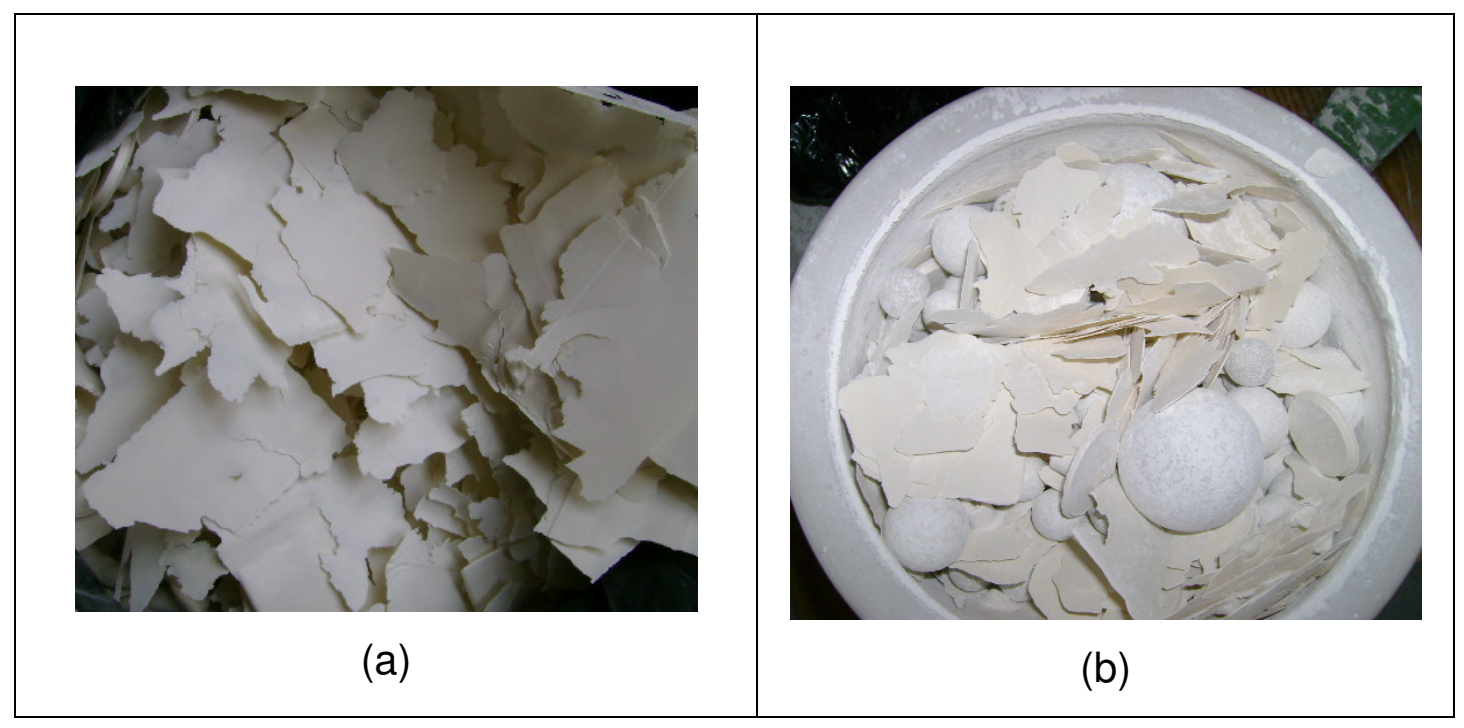

Figura 6.10 - Amostras de BMC para a moagem: a) aparas de BMC e b) aparas colocadas no moinho de bolas.

O pó do BMC alcançou o tamanho mediano de 3,19 $\mu \mathrm{m}$ e esse tamanho de partícula permite vários ensaios de incorporação em outras matérias primas como uma carga. Essa possibilidade vai ao encontro do grande problema apresentado pelos materiais termofixos que por sua impossibilidade de reprocessamento tem grandes volumes destinados aos aterros sanitários. Após o período de moagem de $5 \mathrm{~h}$ os moinhos foram abertos, porém por conta da dureza do BMC nem todas as aparas e peças sólidas foram moídas porque a potência e energia de moagem são limitadas, conforme ilustra a Figura 6.11a, mas boa parte dos resíduos foi moída gerando um pó bastante fino, conforme ilustra a Figura 6.11b. 


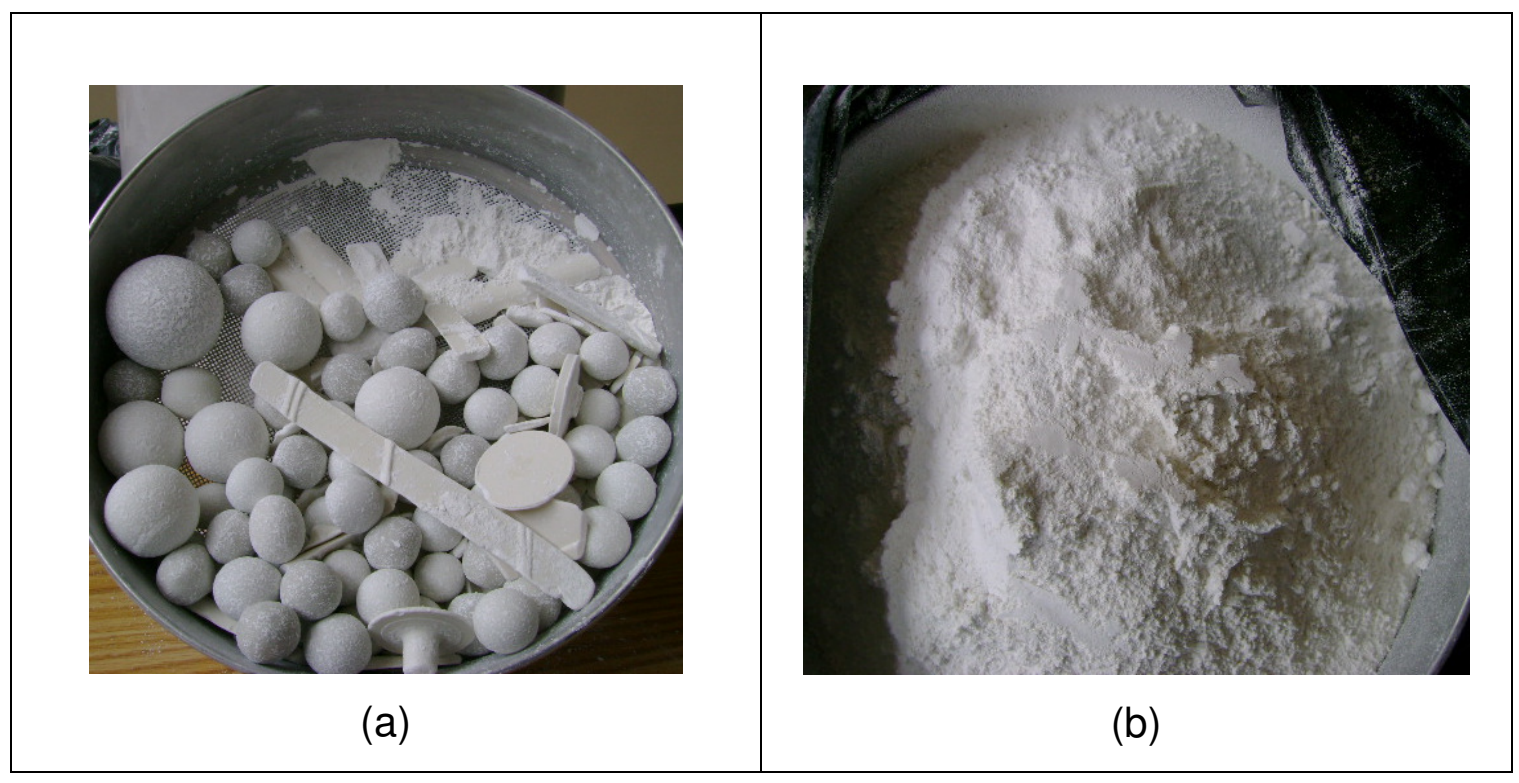

Figura 6.11 - Amostras de BMC após moagem: a) aparas de BMC após moagem na peneira, b) pó de BMC após moagem e passagem por peneira.

Até essa etapa todas as amostras de BMC não tinham verniz ou metal, fato importante de ser considerado, uma vez que dependendo da etapa em que o BMC é segregado poderá apresentar uma camada de verniz e metal ou estar isento desses materiais. O uso do BMC sem o verniz e metal tem como finalidade conhecer qual a influência desses materiais na matriz polimérica que recebeu o resíduo de BMC em pó.

\subsubsection{Análise granulométrica dos resíduos de BMC moído}

A granulometria do pó é importante para as propriedades do material ao qual o mesmo será incorporado uma vez que a dispersão só ocorre se o tamanho das partículas do pó forem bastante reduzidas e numa possível utilização em escala industrial esse parâmetro poderá ser usado como fator de controle de qualidade. 


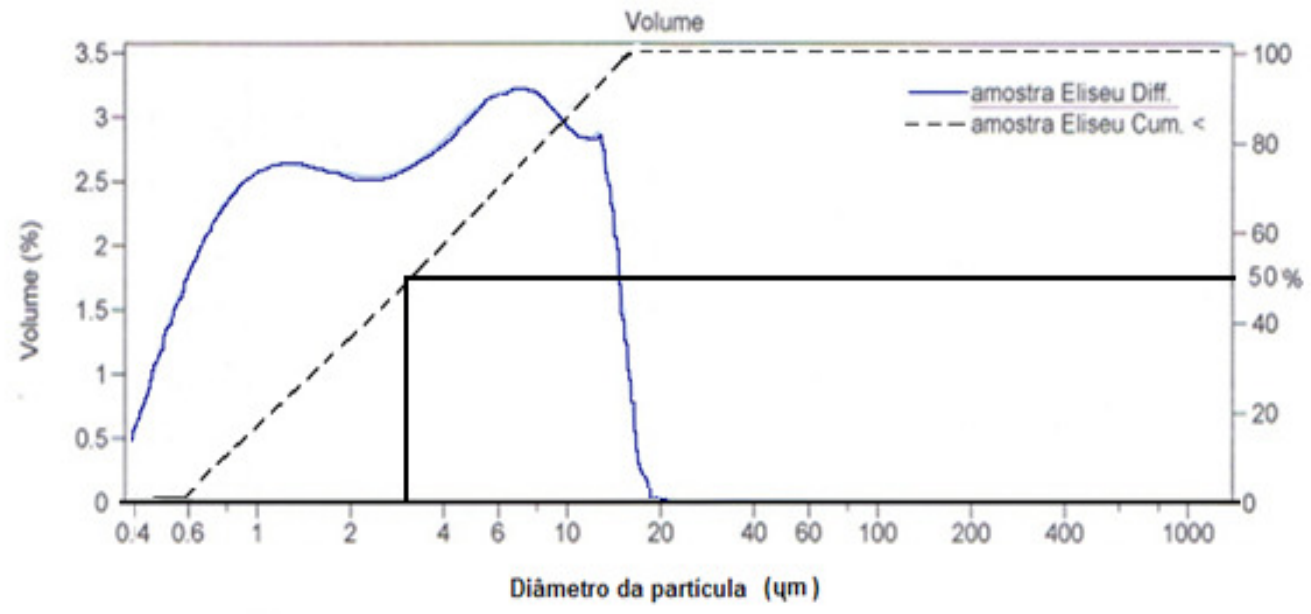

Figura 6.12 - Análise granulométrica do pó de BMC.

6.7.2 Análise do BMC em pó via Infravermelho por transformada de Fourier (FTIR)

A análise dos resíduos de BMC pelo ensaio de infravermelho foi realizada segundo a norma ASTM E 1252 e as bandas representam as possíveis deformações nos grupos químicos presentes nos materiais constituintes do resíduo. A Figura 6.13 ilustra as bandas detectadas durante a análise e o conhecimento dessas é importante para se saber qual a constituição química do material. A Tabela 6.6 apresenta a interpretação dos espectros, classificando por número da onda, formato da onda, intensidade e identificação. O espectro obtido é referente a parte orgânica do BMC, pois esse foi extraído com solvente, ou seja, a porção inorgânica não é contemplada nessa análise. Os resultados apresentados na análise mostram que o processamento, moagem não descaracterizaram quimicamente a amostra de BMC. Uma vez que o resíduo desse compósito termofixo foi incorporado a outro material polimérico, as propriedades desse novo material oriundo da mistura dependem da interação ou não desses materiais de acordo com suas ligações químicas. 


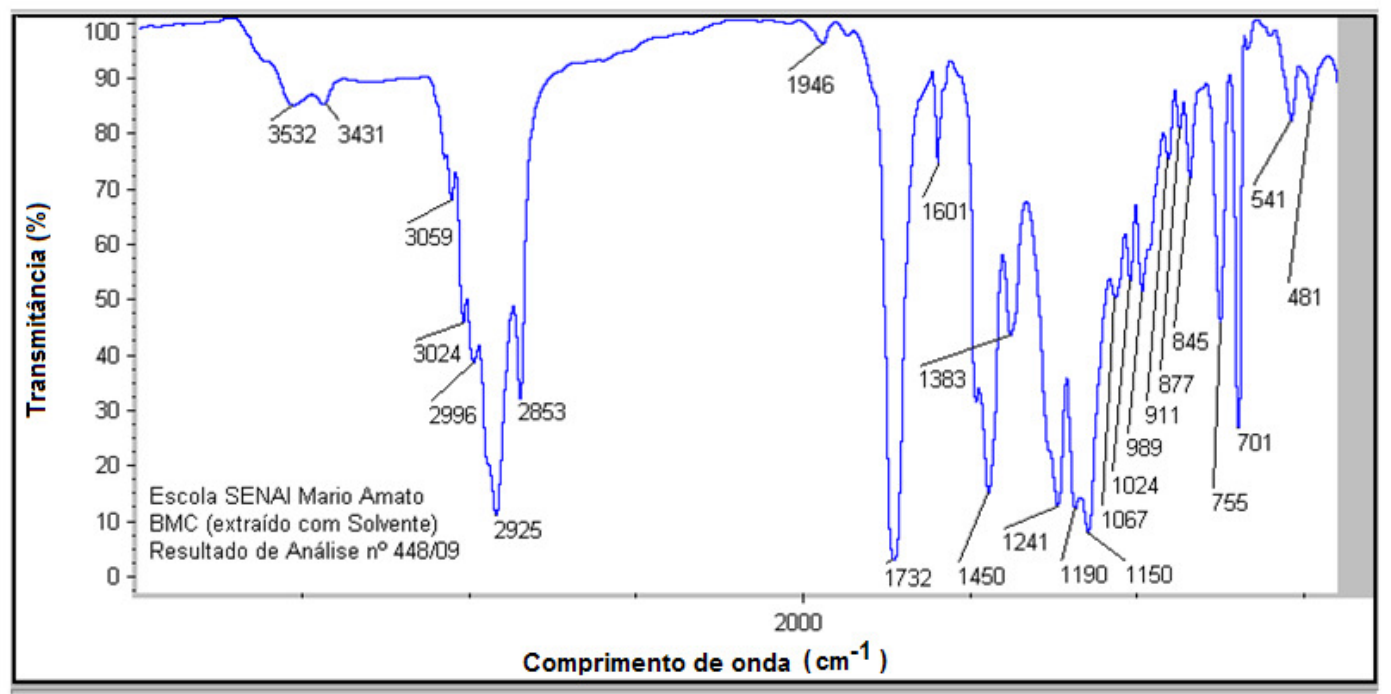

Figura 6.13 - Ensaio de infravermelho do resíduo de BMC moído.

A Tabela 6.6 apresenta as bandas e seus respectivos grupos químicos. 
Tabela 6.6 Interpretação dos principais espectros da amostra de BMC.

\begin{tabular}{|c|c|c|c|c|}
\hline Banda & $\begin{array}{l}N^{0} \text { de Onda } \\
\left(\mathrm{cm}^{-1}\right)\end{array}$ & Formato da banda & Intensidade & Identificaçåo \\
\hline 1 & 3532 & $\begin{array}{c}\text { Agudo alargado na } \\
\text { base }\end{array}$ & Muito fraca & $\begin{array}{l}\text { Essa banda pode vir a caracterizar o primeiro overtone do estiramento } \\
\mathrm{C}=0 \text {, banda } 1732 \mathrm{~cm}^{-1} \text { elou um estiramento de } \mathrm{O}-\mathrm{H} \text {. }\end{array}$ \\
\hline 2 & 3431 & $\begin{array}{l}\text { Agudo alargado na } \\
\text { base }\end{array}$ & Muito fraca & $\begin{array}{l}\text { Essa banda pode vir a caracterizar o primeiro overtone do estiramento } \\
\mathrm{C}=0 \text {, banda } 1732 \mathrm{~cm}^{-1} \text { e/ou um estiramento de } \mathrm{O}-\mathrm{H} \text { ou } \mathrm{N}-\mathrm{H} \text {. }\end{array}$ \\
\hline 3,4 e 5 & $\begin{array}{c}3059,3024 \mathrm{e} \\
2996\end{array}$ & Agudo em ombro & Fraca & Essas bandas podem vir caracterizar estiramentos $\mathrm{C}-\mathrm{H}$ de anel aromático. \\
\hline 6 & 2925 & $\begin{array}{c}\begin{array}{c}\text { Agudo alargado na } \\
\text { base }\end{array} \\
\end{array}$ & Muito forte & Essa banda pode vir a caracterizar um estiramento assimétrico de $\mathrm{CH}_{2}$. \\
\hline 7 & 2853 & Agudo & $\begin{array}{l}\text { Media para } \\
\text { forte }\end{array}$ & Essa banda pode vir a caracterizar um estiramento simetrico de $\mathrm{CH}_{2}$. \\
\hline 8 & 1946 & $\begin{array}{l}\text { Agudo alargado na } \\
\text { base }\end{array}$ & Muito fraca & $\begin{array}{l}\text { Essa banda pode vir a caracterizar uma frequêencia de combinaçào ou } \\
\text { harmonica de anel aromático. }\end{array}$ \\
\hline 9 & 1732 & $\begin{array}{l}\text { Agudo alargado na } \\
\text { base }\end{array}$ & Muito forte & $\begin{array}{l}\text { Essa banda pode vir a caracterizar um estiramento de } \mathrm{C}=\mathrm{O} \text {, banda } \\
\text { caracteristica de ésteres alifáticos saturados. }\end{array}$ \\
\hline 10 & 1601 & Agudo & Fraca & Essa banda pode vir a caracterizar um estiramento $\mathrm{C}-\mathrm{C}$ de anel aromático. \\
\hline 11 & 1450 & Agudo alargado & Forte & $\begin{array}{l}\text { Essa banda pode vir a caracterizar uma deformaç̧o angular assimétrica de } \\
\mathrm{CH}_{3} \text {. }\end{array}$ \\
\hline 12 & 1383 & Agudo & Média & $\begin{array}{l}\text { Essa banda pode vir a caracterizar uma deformaçăo angular simétrica de } \\
\mathrm{CH}_{3} \text {. }\end{array}$ \\
\hline 13 & 1241 & $\begin{array}{l}\text { Agudo alargado na } \\
\text { base }\end{array}$ & Muito forte & $\begin{array}{l}\text { Essa banda pode vir a caracterizar um estiramento assimétrico de } \\
\mathrm{C}-\mathrm{C}(=0)-0 \text {, banda caracteristica de ésteres alifáticos saturados, banda } \\
\text { presente em acrilatos. }\end{array}$ \\
\hline 14 & 1190 & $\begin{array}{l}\text { Agudo alargado na } \\
\text { base }\end{array}$ & Muito forte & $\begin{array}{l}\text { Essa banda pode vir a caracterizar um estiramento assimétrico de } \\
\mathrm{C}-\mathrm{C}-\mathrm{O} \text {, banda caracteristica de ésteres alifaticos saturados, banda } \\
\text { presente em acrilatos. }\end{array}$ \\
\hline 15 & 1150 & $\begin{array}{l}\text { Agudo alargado na } \\
\text { base }\end{array}$ & Muito forte & $\begin{array}{l}\text { Essa banda pode vir a caracterizar um estiramento assimétrico de } \\
\text { C-O-C, banda caracteristica de ésteres alifáticos saturados, banda } \\
\text { presente em acrilatos. }\end{array}$ \\
\hline
\end{tabular}

\subsubsection{O uso do resíduo de BMC nas formulações de PVC rígido}

O pó obtido a partir da moagem do BMC foi incorporado em formulações de PVC rígido nas proporções de 5 e de 10 PCR (partes por cem de resina). Foram preparadas duas formulações comuns de PVC rígido usando 0 carbonato de cálcio como carga para comparação com as formulações de PVC com BMC, conforme listado na Tabela 5.2. 
6.7.3.1 Resistência à tração dos compostos de $\mathrm{PVC} \operatorname{com~} \mathrm{CaCO}_{3}$ e $\mathrm{BMC}$.

A Tabela 6.8 apresenta os valores encontrados no ensaio de resistência à tração das formulações com 5 PCR de carbonato de cálcio e BMC.

Tabela 6.8 - Resultados do ensaio de resistência à tração dos compostos com 5 PCR de $\mathrm{CaCO}_{3}, 5 \mathrm{PCR}$ de $\mathrm{BMC}$ e 5 PCR DE BMC metalizado.

\begin{tabular}{|c|c|c|c|c|c|c|}
\hline & \multicolumn{2}{|c|}{ Formulação 1} & \multicolumn{2}{|c|}{ Formulação 2} & \multicolumn{2}{|c|}{ Formulação 3} \\
\hline & $\begin{array}{c}\text { PVC } \\
05 \mathrm{PCR} \\
\mathrm{CaCO}_{3}\end{array}$ & $\begin{array}{l}\text { Desvio } \\
\text { padrão }\end{array}$ & $\begin{array}{l}\text { PVC } \\
05 \text { PCR } \\
\text { BMC }\end{array}$ & $\begin{array}{l}\text { Desvio } \\
\text { padrão }\end{array}$ & $\begin{array}{c}\text { PVC } \\
05 \text { PCR } \\
\text { BMC + } \\
\text { metal } \\
\end{array}$ & $\begin{array}{l}\text { Desvio } \\
\text { padrão }\end{array}$ \\
\hline $\begin{array}{c}\text { Força } \\
\text { máxima }(k N)\end{array}$ & 2,16 & 0,10 & 2,54 & 0,11 & 2,42 & 0,19 \\
\hline $\begin{array}{l}\text { Tensão } \\
\text { força } \\
\text { máxima } \\
(\mathrm{MPa})\end{array}$ & 54,40 & 1,01 & 56,02 & 0,54 & 53,83 & 4,44 \\
\hline $\begin{array}{c}\text { Tensão de } \\
\text { ruptura } \\
\text { (MPa) }\end{array}$ & 39,98 & 5,29 & 39,97 & 1,42 & 42,10 & 3,37 \\
\hline $\begin{array}{l}\text { Alongamento } \\
\text { na ruptura } \\
(\mathrm{mm})\end{array}$ & 12,92 & 3,89 & 17,37 & 7,19 & 9,71 & 3,51 \\
\hline $\begin{array}{c}\text { Deformação } \\
\text { de ruptura } \\
(\%)\end{array}$ & 11,24 & 3,38 & 15,11 & 6,25 & 8,44 & 3,05 \\
\hline $\begin{array}{l}\text { Módulo de } \\
\text { elasticidade } \\
\text { (MPa) }\end{array}$ & 2749,66 & 70,38 & 2692,82 & 107,6 & 2662,50 & 115,13 \\
\hline
\end{tabular}

Comparando-se os valores de resistência à tensão na ruptura é possível observar que os valores encontrados para as formulações 1 e 2 são praticamente iguais e a formulação 3 ligeiramente maior. A maior deformação da formulação 2 conforme representado na Figura $6.14 a$, mostra que a formulação 1 é menos tenaz. A formulação 3 apresentou menor deformação 0 que é coerente com o maior valor de resistência à tensão de ruptura conforme representado nas Figuras 6.14a e 6.14b. 


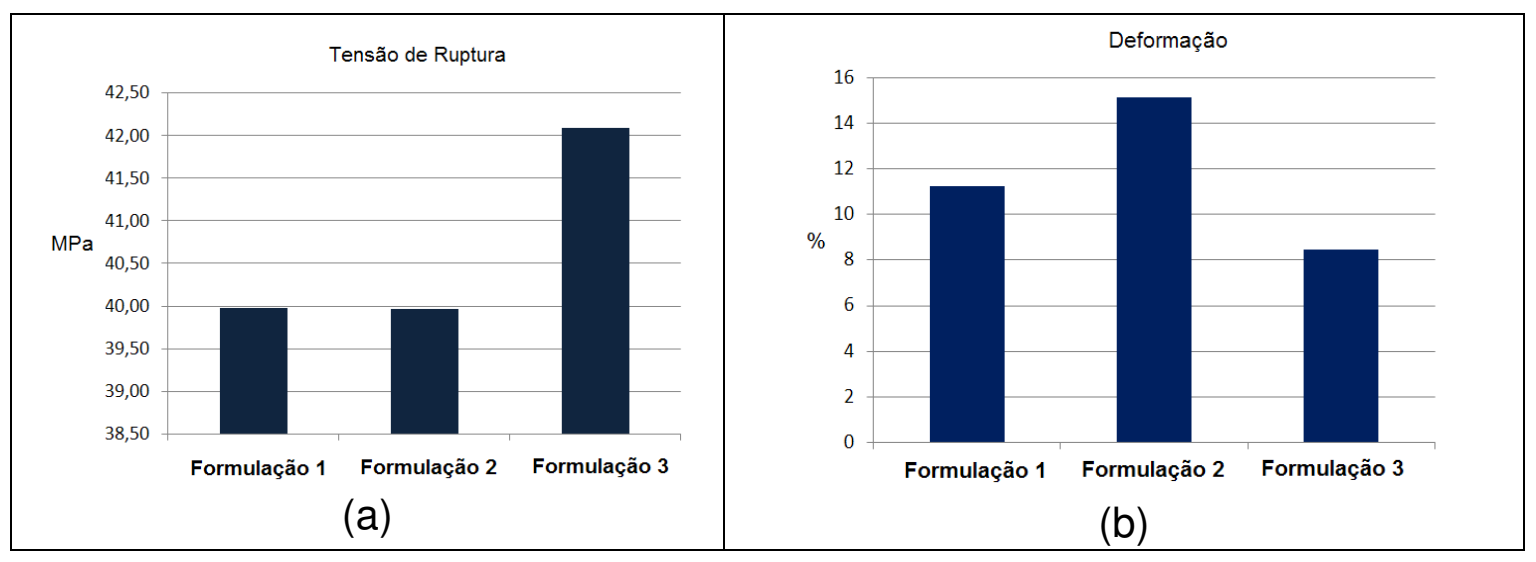

Figura 6.14 - Comparativo de resistência à tensão de ruptura e deformação dos compostos de PVC com 5 PCR de $\mathrm{CaCO}_{3}$ e 5 PCR de $\mathrm{BMC}$ em pó.

A Tabela 6.9 apresenta os resultados de resistência à tração realizado nas formulações 4,5 e 6 , onde é possível constatar a melhora nas propriedades mecânicas.

Em condições normais, quando se incorpora algum resíduo ou carga em materiais termoplásticos a expectativa é de perda de propriedades, principalmente as mecânicas, quando comparado ao termoplástico puro. Os resultados para as formulações com 10 PCR nos ensaios de resistência à tração foram satisfatórios. 
Tabela 6.9 - Resultados do ensaio de resistência à tração dos compostos com 10 PCR de $\mathrm{CaCO}_{3}$ e 10 PCR de BMC.

\begin{tabular}{|c|c|c|c|c|c|c|}
\hline & \multicolumn{2}{|c|}{ Formulação 4} & \multicolumn{2}{|c|}{ Formulação 5} & \multicolumn{2}{|c|}{ Formulação 6} \\
\hline & $\begin{array}{c}\mathrm{PVC} \\
10 \mathrm{PCR} \\
\mathrm{CaCO}_{3}\end{array}$ & $\begin{array}{l}\text { Desvio } \\
\text { padrão }\end{array}$ & $\begin{array}{l}\text { PVC } \\
10 \text { PCR } \\
\text { BMC }\end{array}$ & $\begin{array}{l}\text { Desvio } \\
\text { padrão }\end{array}$ & $\begin{array}{c}\text { PVC } \\
10 \text { PCR } \\
\text { BMC + } \\
\text { metal }\end{array}$ & $\begin{array}{l}\text { Desvio } \\
\text { padrão }\end{array}$ \\
\hline $\begin{array}{c}\text { Força } \\
\text { máxima }(\mathrm{kN})\end{array}$ & 2,53 & 0,16 & 2,27 & 0,06 & 2,57 & 0,15 \\
\hline $\begin{array}{l}\text { Tensāo } \\
\text { força } \\
\text { máxima } \\
(\mathrm{MPa})\end{array}$ & 50,91 & 2,50 & 54,41 & 2,34 & 53,36 & 0,66 \\
\hline $\begin{array}{l}\text { Tensão de } \\
\text { ruptura } \\
\text { (MPa) }\end{array}$ & 37,61 & 3,12 & 39,94 & 1,82 & 43,66 & 3,57 \\
\hline $\begin{array}{l}\text { Alongamento } \\
\text { na ruptura } \\
(\mathrm{mm})\end{array}$ & 14,20 & 3,83 & 12,12 & 2,03 & 9,03 & 2,06 \\
\hline $\begin{array}{l}\text { Deformação } \\
\text { de ruptura } \\
(\%)\end{array}$ & 12,35 & 5,07 & 10,53 & 1,06 & 7,85 & 1,79 \\
\hline $\begin{array}{l}\text { Módulo de } \\
\text { elasticidade } \\
\text { (MPa) }\end{array}$ & 2843,47 & 40,42 & 2856,55 & 157,30 & 2769,85 & 67,87 \\
\hline
\end{tabular}

$\mathrm{Na}$ comparação da formulação $4 \mathrm{com}$ as formulações 5 e 6 observa-se um incremento nas propriedades mecânicas. Analisando-se os valores de alongamento e deformação é possível perceber que estes são inversamente proporcionais aos valores de tensão na força máxima e tensão na ruptura. $A$ Figura 6.15a ilustra uma considerável melhora das propriedades na resistência à tensão de ruptura, principalmente da formulação 6 . Considerando-se os valores de deformação para as formulações 4,5 e 6 nota-se coerência com os valores de resistência à tensão.

Os resultados levantados a partir dos ensaios de determinação de resistência à tração desperta o interesse em se incorporar outros teores de BMC às formulações de PVC e continuar a comparação com o carbonato de cálcio, uma vez que existem formulações com até 30 partes por cem de resina desse tipo de carga. 


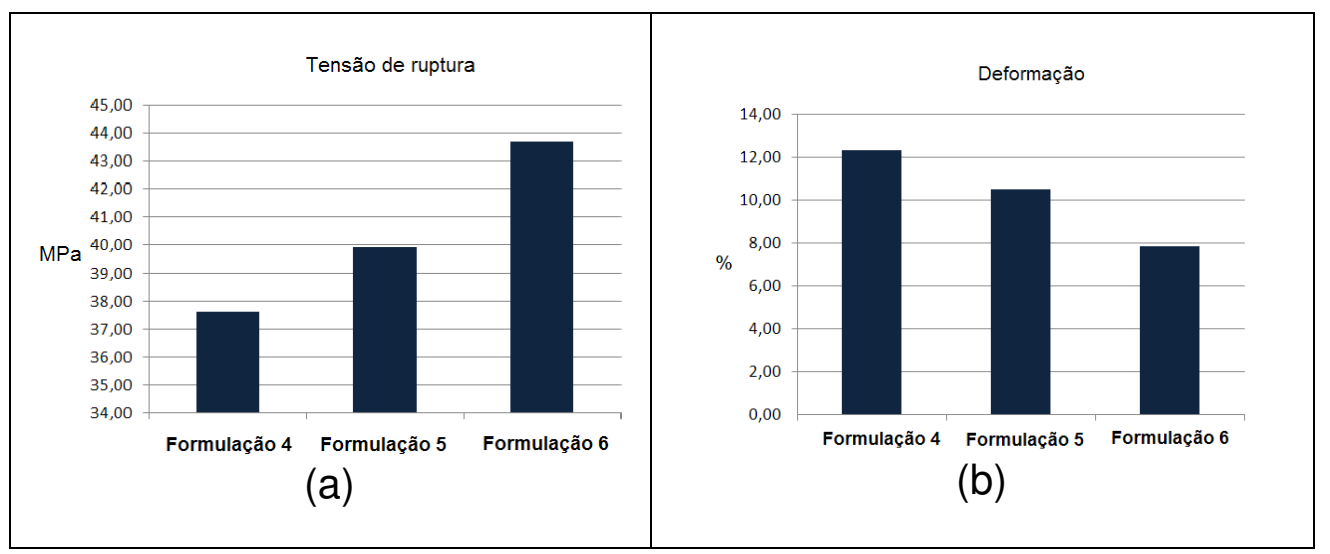

Figura 6.15 - Ensaio de resistência à tração dos compostos de PVC com 10 PCR de $\mathrm{CaCO}_{3}$ e 10 PCR de BMC em pó:

a) tensão de ruptura, b) e deformação

6.7.3.2 Resistência ao impacto dos compostos de $\mathrm{PVC} c o m \mathrm{CaCO}_{3} \mathrm{e}$ BMC.

O ensaio de resistência ao impacto foi realizado com o propósito de se avaliar a influencia do BMC na tenacidade do PVC. A Tabela 6.10 apresenta os valores de resistência ao impacto para as formulações 1, 2 e 3 que apresentam 5 PCR de carbonato de cálcio e de BMC. Os valores foram expressos nas unidades de J.m $\mathrm{m}^{-1}$ e de $\mathrm{kJ} . \mathrm{m}^{-2}$, para facilitar uma possível comparação com outros materiais.

Tabela 6.10 - Resultados do ensaio de resistência ao impacto dos compostos com 05 PCR de $\mathrm{CaCO}_{3}$ e 05 PCR de BMC.

\begin{tabular}{ccccccc}
\hline & Formulação 1 & Formulação 2 & \multicolumn{2}{c}{$\begin{array}{l}\text { Formulação 3 } \\
\text { PVC }\end{array}$} \\
& $\begin{array}{c}\text { PVC } \\
\text { 05 PCR } \\
\mathrm{CaCO}_{3}\end{array}$ & $\begin{array}{c}\text { Desvio } \\
\text { padräo }\end{array}$ & $\begin{array}{c}\text { PVC } \\
\text { 05 PCR } \\
\text { BMC }\end{array}$ & $\begin{array}{c}\text { Desvio } \\
\text { padrão }\end{array}$ & $\begin{array}{c}\text { 05 PCR } \\
\text { BMC + } \\
\text { metal }\end{array}$ & $\begin{array}{c}\text { Desvio } \\
\text { padräo }\end{array}$ \\
\hline $\begin{array}{c}\text { Resistência } \\
\text { ao impacto } \\
\left(\mathrm{J} . \mathrm{m}^{-1}\right)\end{array}$ & 29,49 & 1,38 & 28,76 & 1,36 & 30,38 & 2,30 \\
$\begin{array}{c}\text { Resistência } \\
\text { ao impacto } \\
\left(\mathrm{kJ} \cdot \mathrm{m}^{-2}\right)\end{array}$ & 2,90 & 0,14 & 2,83 & 0,13 & 2,99 & 0,23 \\
\hline
\end{tabular}


Os valores apresentados no ensaio de resistência ao impacto da formulação 1 não foram significativamente diferentes da formulações 2 e 3 ou seja, a presença dos resíduos de BMC não comprometeu a resistência ao impacto para o teor de 5 PCR. A Figura 6.16 ilustra os valores e a formulação 3 houve uma melhora na resistência ao impacto apresentada pelo composto.

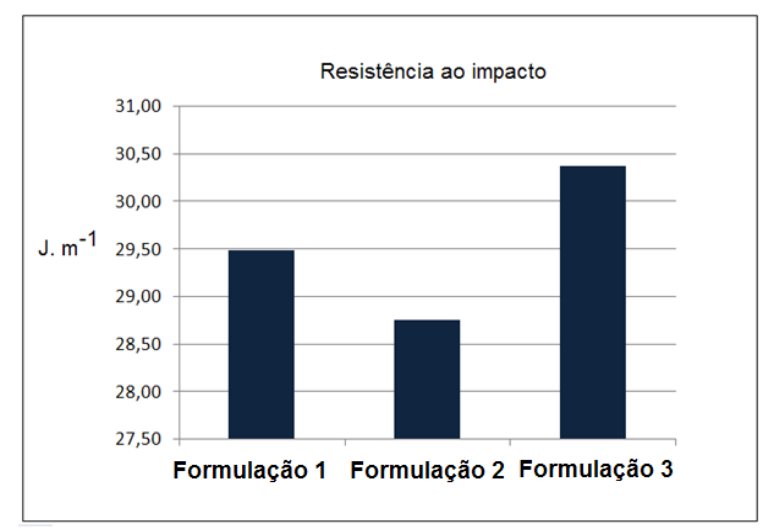

Figura 6.16 - Comparativo de resistência ao impacto dos compostos de PVC com 05 PCR de $\mathrm{CaCO}_{3}$ e 05 PCR de BMC em pó.

A Tabela 6.11 apresenta os valores de resistência ao impacto de todas as formulações com $10 \mathrm{PCR}$ de $\mathrm{CaCO}_{3}$ e de $\mathrm{BMC}$. As unidades referentes ao ensaio realizado são respectivamente $\mathrm{J}^{-1} \mathrm{~m}^{-1} \mathrm{e} \mathrm{kJ} \cdot \mathrm{m}^{-2}$. Essa diferença de unidade e de valores para uma mesma formulação é por conta da norma utilizada.

Tabela 6.11 - Resultados do ensaio de resistência ao impacto dos compostos com 10 PCR de $\mathrm{CaCO}_{3}$ e 10 PCR de BMC.

\begin{tabular}{ccccccc}
\hline & Formulação 4 & \multicolumn{2}{c}{ Formulação 5 } & \multicolumn{2}{c}{ Formulação 6 } \\
\hline & $\begin{array}{c}\text { PVC } \\
10 \mathrm{PCR}\end{array}$ & $\begin{array}{c}\text { Desvio } \\
\mathrm{CaCO}_{3}\end{array}$ & $\begin{array}{c}\text { PVC } \\
\text { padräo } \\
\text { BMC }\end{array}$ & $\begin{array}{c}\text { Desvio } \\
\text { padräo }\end{array}$ & $\begin{array}{c}\text { PVC } \\
\text { 10 PCR } \\
\text { BMC + } \\
\text { metal }\end{array}$ & $\begin{array}{c}\text { Desvio } \\
\text { padrão }\end{array}$ \\
\hline $\begin{array}{c}\text { Resistência } \\
\text { ao impacto } \\
\left(\mathrm{J}^{-1} \mathrm{~m}^{-1}\right)\end{array}$ & 31,68 & 2,8 & 29,05 & 2,17 & 30,38 & 2,15 \\
$\begin{array}{c}\text { Resistência } \\
\text { ao impacto } \\
\left(\mathrm{kJ} . \mathrm{m}^{-2}\right)\end{array}$ & 3,12 & 0,28 & 2,86 & 0,21 & 2,99 & 0,23 \\
\hline
\end{tabular}


Os resultados de resistência ao impacto para as formulações com 10 PCR de carbonato de cálcio e de BMC apresentaram valores muito próximos. Embora o BMC não tenha melhorado a resistência ao impacto também não prejudicou acentuadamente.

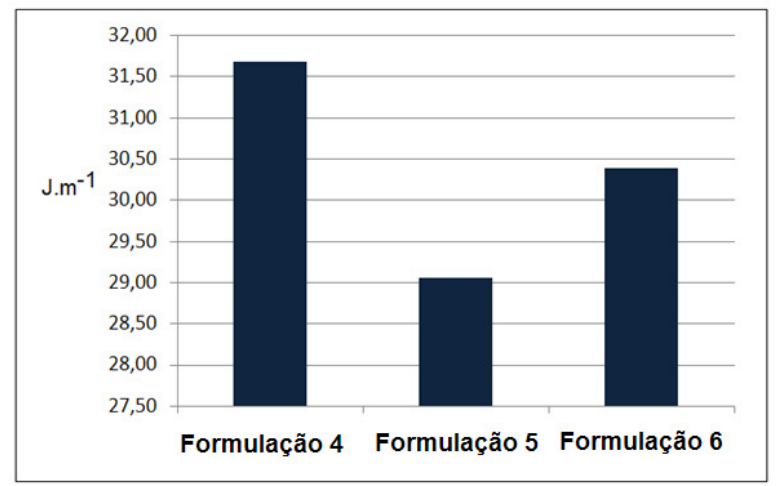

Figura 6.17 - Comparativo de resistência ao impacto dos compostos de PVC com 10 PCR de $\mathrm{CaCO}_{3}$ e 10 PCR de BMC em pó.

\subsubsection{Determinação da temperatura de amolecimento Vicat do composto de PVC com diferentes teores de BMC.}

Nas formulações com 5 PCR de carbonato de cálcio e de BMC, conforme representado nas Tabela 6.11 e 6.12 praticamente não houve alteração nas temperaturas de amolecimento, e a incorporação do resíduo não interferiu negativamente nessa propriedade.

Tabela 6.11 - Resultados do ensaio de temperatura de amolecimento Vicat dos compostos com $05 \mathrm{PCR}$ de $\mathrm{CaCO}_{3}$ e $05 \mathrm{PCR}$ de BMC.

\begin{tabular}{lcccccc}
\hline & Formulação 1 & Formulação 2 & \multicolumn{2}{c}{ Formulação 3 } \\
\hline & $\begin{array}{c}\text { PVC } \\
\text { 05 PCR } \\
\mathrm{CaCO}_{3}\end{array}$ & $\begin{array}{c}\text { Desvio } \\
\text { padräo }\end{array}$ & $\begin{array}{c}\text { PVC } \\
\text { 05CR } \\
\text { BMC }\end{array}$ & $\begin{array}{c}\text { Desvio } \\
\text { padräo }\end{array}$ & $\begin{array}{c}\text { P5 PCR } \\
\text { BMC + } \\
\text { metal }\end{array}$ & $\begin{array}{c}\text { Desvio } \\
\text { padrão }\end{array}$ \\
\hline $\begin{array}{c}\text { Temperatura } \\
\text { de } \\
\text { amolecimento } \\
\text { Vicat }{ }^{\circ} \mathrm{C}\end{array}$ & 80,0 & 0,6 & 82,0 & 0,1 & 82,1 & 0,2 \\
\hline
\end{tabular}


Os resultados apresentados para o ensaio de temperatura de amolecimento Vicat para as formulações com 10 PCR de carbonato de cálcio e com BMC apresentaram valores bastante próximos, conforme representado na Tabela 6.12.

Tabela 6.12 - Resultados do ensaio de temperatura de amolecimento Vicat dos compostos com $10 \mathrm{PCR}$ de $\mathrm{CaCO}_{3}$ e $10 \mathrm{PCR}$ de BMC.

\begin{tabular}{|c|c|c|c|c|c|c|}
\hline & \multicolumn{2}{|c|}{ Formulação 4} & \multicolumn{2}{|c|}{ Formulação 5} & \multicolumn{2}{|c|}{ Formulação 6} \\
\hline & $\begin{array}{c}\text { PVC } \\
10 \mathrm{PCR} \\
\mathrm{CaCO}_{3}\end{array}$ & $\begin{array}{l}\text { Desvio } \\
\text { padräo }\end{array}$ & $\begin{array}{c}\text { PVC } \\
10 \text { PCR } \\
\text { BMC }\end{array}$ & $\begin{array}{l}\text { Desvio } \\
\text { padräo }\end{array}$ & $\begin{array}{c}\text { PVC } \\
10 \mathrm{PCR} \\
\text { BMC + } \\
\text { metal } \\
\end{array}$ & $\begin{array}{l}\text { Desvio } \\
\text { padräo }\end{array}$ \\
\hline $\begin{array}{c}\text { Temperatura } \\
\text { de } \\
\text { amolecimento } \\
\text { Vicat }{ }^{\circ} \mathrm{C}\end{array}$ & 81,0 & 0,1 & 80,5 & 0,4 & 82,1 & 0,2 \\
\hline
\end{tabular}

6.7.3.4 Determinação das condições de gelificação do composto de PVC com diferentes teores de BMC.

O ensaio para determinação da gelificação é realizado para o PVC por conta do comportamento reológico apresentado por esse e também por se tratar de um material que na realidade é um composto, ou seja, o resultado de uma mistura de resina de PVC com outros componentes com funções distintas nas propriedades e nas características de processamento. A gelificação é um estagio que precede a plastificação do material e quando essa ocorre num tempo menor é algo satisfatório para o processo pelo fato de ter uma correlação com a produtividade do equipamento, ou seja, quando determinado composto de PVC gelifica mais rapidamente a quantidade de material processado em massa por unidade de tempo é maior quando comparado a um composto que gelifique num tempo maior. A gelificação depende do atrito gerado entre os grãos ou aglomerados entre si e do também da fricção desses com o equipamento. 
Tabela 6.13 - Resultados do ensaio de gelificação compostos com 05 e $10 \mathrm{PCR}$ de $\mathrm{CaCO}_{3}$ e 05 e 10 PCR de BMC.

\begin{tabular}{lcccc}
\hline \multicolumn{5}{c}{ Ensaio de gelificação } \\
\hline & $\begin{array}{c}\text { Tempo } \\
(\mathbf{m i n})\end{array}$ & $\begin{array}{c}\text { Temperatura } \\
\left({ }^{\circ} \mathbf{C}\right)\end{array}$ & $\begin{array}{c}\text { Torque } \\
(\mathbf{N m})\end{array}$ & $\begin{array}{c}\text { Energia } \\
(\mathbf{k J})\end{array}$ \\
\hline Formulação 1 & 2,15 & 161 & 5,59 & 64,50 \\
Formulação 2 & 2,01 & 162 & 6,10 & 66,10 \\
Formulação 3 & 0,98 & 154 & 8,09 & 54,60 \\
Formulação 4 & 2,50 & 162 & 4,79 & 59,80 \\
Formulação 5 & 2,68 & 159 & 6,36 & 91,80 \\
Formulação 6 & 0,98 & 162 & 7,67 & 51,20 \\
\hline
\end{tabular}

Os valores apresentados na Tabela 6.13 para as 6 formulações de PVC são importantes pelo fato de fornecer informações sobre o comportamento do material durante o processamento. As formulações 3 e 6 foram as que gelificaram em tempo menor que 1 minuto e estas são as formulações onde 0 equipamento registrou maior valor de torque, o que é coerente para processos de maior produtividade. $O$ aumento do torque é conseqüência da densificação do composto, o que requer maior "esforço" do equipamento para processar o material. Na gelificação, a densificação do composto se torna mais intensa e o material adquire um estado de gel com fraca interação entre as partículas e o fluxo ainda é particulado, porém o material continua sofrendo cisalhamento até que ocorra a fusão. A Tabela 6.14 registra as temperaturas onde ocorreu a fusão das 6 formulações de PVC com carbonato de cálcio e BMC. Comparando os valores nota-se que não houve diferença significativa de temperatura, o que variou mais significativamente foi o tempo de fusão que para as formulações 3 e 6 foram menores, coerente com os tempos de gelificação para as mesmas 
formulações. Na comparação dos valores de torque no momento da fusão das formulações nota-se variação pouco significativa.

Tabela 6.14 - Resultados do ensaio de gelificação compostos com 05 e 10 PCR de $\mathrm{CaCO}_{3}$ e 05 e 10 PCR de BMC.

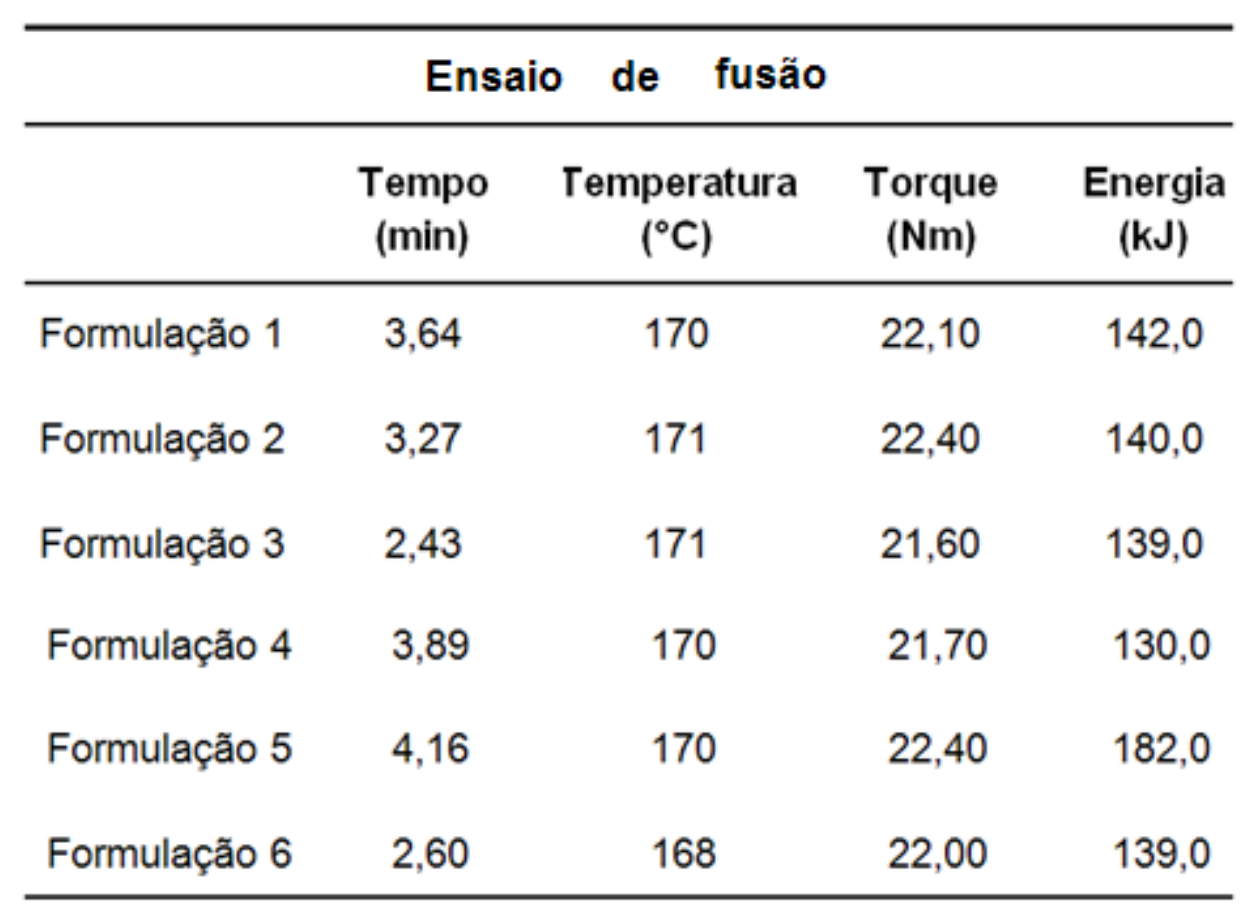




\section{CONCLUSÕES}

O PEl quando submetido ao ensaio de tração apresentou maior resistência e maior deformação que o BMC, na tensão de ruptura $83 \mathrm{MPa}$ para - PEI e 47,6 \% de deformação enquanto o BMC na tensão de ruptura apresentou $29 \mathrm{MPa}$ e deformação de $1 \%$. A fratura apresentada pelos corpos de prova dos dois materiais ensaiados evidenciou as diferenças entre o PEI e o BMC. No primeiro, a fratura ficou perpendicular à direção da carga, indicando uma fratura por tração pura, enquanto que no segundo houve evidencia de uma falha transversal mostrando a possibilidade da ocorrência de cisalhamento

Embora a resistência à tração apresentada pelo PEI seja superior ao do $\mathrm{BMC}$, o que pode ser visto como aspecto positivo há a ocorrência de uma maior deformação bem mais acentuada, o que poderia comprometer o bom funcionamento do farol. Como as solicitações mecânicas nos refletores são inferiores aos valores obtidos, ambos os materiais poderiam ser utilizados para a fabricação de refletores.

Nos ensaios térmicos o BMC apresentou melhores propriedades que o PEI. No ensaio para determinação da temperatura de deflexão térmica a deformação do BMC foi de apenas $0,03 \mathrm{~mm}$ ao atingir a temperatura de 265,8 ${ }^{\circ} \mathrm{C}$, enquanto a deformação do $\mathrm{PEI}$ foi de $0,32 \mathrm{~mm}$ ao atingir a temperatura de $184,1^{\circ} \mathrm{C}$. Essa propriedade é importante para os refletores, que constantemente é solicitado termicamente e não pode deformar para não comprometer o funcionamento do farol do automóvel. Sob o ponto de vista dessa propriedade, o BMC é mais adequado para a fabricação dos refletores. O ensaio para determinação da temperatura de amolecimento Vicat pôde comprovar a superior resistência térmica do BMC frente ao PEI. À temperatura de $198,2^{\circ} \mathrm{C}$, uma agulha com $1 \mathrm{~mm}^{2}$ penetrou no corpo de prova de PEI e no corpo de prova de BMC não é possível a penetração da agulha mesmo temperaturas maiores.

No ensaio de calcinação o BMC apresentou em sua composição teor de inorgânicos superior a 50\%, o que colabora para redução das propriedades mecânicas. Os materiais inorgânicos colocados em maior quantidade numa formulação de BMC para fabricação de refletores são o carbonato de cálcio e a fibra de vidro, que pode ser confirmado na análise de espectroscopia de raio $X$ 
realizada nos resíduos oriundos da calcinação do BMC. O resíduo após aquecimento para determinação da perda ao fogo foi de $950{ }^{\circ} \mathrm{C}$ apresentou $24,64 \%$ de $\mathrm{SiO}_{2}$ oriundo da fibra de vidro e $51,11 \%$ de $\mathrm{CaO}$ oriundo do carbonato de cálcio $\left(\mathrm{CaCO}_{3}\right)$.

O ensaio de termogravimetria mostra também a elevada a resistência térmica do BMC, uma vez que a perda de massa em função do aumento da temperatura só foi significativa a partir dos $300{ }^{\circ} \mathrm{C}$. Esse ensaio além de fornecer informações sobre a perda de massa do BMC pôde comprovar que os teores de inorgânicos acima de $50 \%$, conforme obtidos no ensaio de calcinação.

A fabricação dos refletores em BMC envolve um número maior de etapas se comparadas à produção de refletores com o PEl. Isso representa um fator desfavorável, não só pelo aumento de custo, mas também pela maior possibilidade de defeitos na peça, o que gera descarte e consequente comprometimento da produtividade.

O PEI por sua vez necessita de menos equipamentos para ser processado. Contudo, o preço dessa resina sendo elevado onera o produto tornando-o mais caro que o BMC. Outro aspecto positivo é que as sobras e descartes do processo podem ser recuperadas, o que acontece que não acontece com o BMC, em que as mesmas e até mesmo o produto final são destinados aos aterros sanitários, fato que contraria as políticas ambientais adotadas em muitos países.

Antevendo para um futuro breve uma legislação que proíba o descarte do BMC em aterros, foram realizados ensaios incorporando o BMC ao PVC. Foi feita moagem de resíduos do BMC obtendo-se resíduos de granulometria mediano de 3,19 $\mu \mathrm{m}$, valores obtidos a partir da análise de difração de raios $X$.

A moagem do BMC em dimensões reduzidas não comprometeu quimicamente o material, pois no ensaio de infravermelho por transformada de Fourier foram detectados os grupos químicos esperados para a parte orgânica do $B M C$, que foi separada do inorgânico com o uso de um solvente apropriado. A incorporação dos resíduos de BMC ao PVC apresentou propriedades mecânicas e térmicas equivalentes ou até superiores em comparação ao PVC com carbonato de cálcio. Foram moídos refletores fabricados com e sem camada de metal e verniz e não foram detectadas significativas diferenças, 
com exceção do ensaio de gelificação e fusão que aconteceram em tempo menor que as formulações de BMC puro e de carbonato de cálcio.

O estudo do reaproveitamento do BMC pela incorporação no PVC levou a concluir que é possível introduzir nas formulações esse material como carga, sem que o mesmo interfira nas propriedades do PVC. 


\section{REFERÊNCIAS}

ASSOCIAÇÃO BRASILEIRA DE MATERIAIS COMPÓSITOS - ABMACOTermofixos investem na reciclagem. Disponível em:

<http://www.abmaco.org.br> 14 jul 2009

ANDRADE, Cristina T.; COUTINHO, Fernanda M. B.; DIAS, Marcos L.; LUCAS, F. Elizabete; OLIVEIRA, Clara Marize F.; TABAK, David - Compêndio de Nomenclatura Macromolecular - IUPAC, Ed. E-paper Rio de Janeiro, 2002

ANDRADY, Anthony L. - Plastics and the environment, New Jersey (USA) John Wiley and sons, 2003

ARTEB, Centro Tecnológico. A História da lluminação Veicular. Encarte comemorativo 70 anos. São Paulo, 2004.

BOSCH. Manual de Tecnologia Automotiva - Distribution: SAE Society if Automotive Engineers. ISBN 0-7680-0669-4. 5th. Edition. 2000

BRASKEM -

Disponível em: http://www.braskem.com.br/plasticoverde/principal.html. Acesso em:12 jun 2009

BRYDSON, John, PLASTICS MATERIALS, 7a. Edition, University of North London, 2005

European Alliance for SMC - Bulk Moulding Compound

Disponível em: <http://www.smc-alliance.com/publications/bulk.pdf>.

Acesso em: 12 set 2007.

CALLISTER Jr, William D., Ciência dos Materiais - 7ª Edição, Editora LTC, Rio de Janeiro, 2008. 
CARDOSO, Eduardo, Estudo da espuma metálica no design automotivo. Porto Alegre, 2009, 172p. Dissertação (Mestrado em Design e Tecnologia) Universidade Federal do Rio Grande do Sul, Porto Alegre, 2009. In: ASHBY, Michael F. Metal Foams: A Design Guide. Butterworth-Heinemann, Oxford,2000

CANeVAROlo, S. V., Ciência dos Polímeros, São Paulo - Artliber Editora, 2006

CHANDA, Manas; ROY, Salil K.; Plastics Technology Handbook - New York CRC Press $-4^{\circ}$ Edition -2006

COSTA, Gustavo Garcia da, Avaliação da Influência dos Ciclos Térmicos na Propriedades dos Compósitos Termoplásticos de PPS e PEI com fibras de Carbono e Vidro Prensados Conformados por Prensagem à Quente. São José dos Campos, 2006, Dissertação (Mestrado em Engenharia Aeronáutica e Mecânica), 2006

DOMININGHAUS, H., Plastics for Engineers: Materials, Properties, Applications (Tradução by John Haim and David Hyatt) - Munique; Viena; Nova Yorque; Barcelona: Hanser, 1993.

EPELBAUM, Michel, $\boldsymbol{A}$ influência da gestão ambiental na competitividade e no sucesso empresarial, São Paulo, 2004, 190p. Dissertação (Mestrado em Engenharia de Produção) Universidade de São Paulo, São Paulo, 2004.

GNAUCK, Bernhard; FRÜNDT, Peter, Iniciación a la Química de los Plásticos, Hanser, 1를 Edición, Barcelona, Hanser Editorial, 1992

HARPER, A. Charles, Handbook of plastics, elastomers and composites.

Disponível em: <www.digitalengineeringlibrary.com> $4^{\circ}$ Edition, 2004

KIA, Hamid G., Sheet Molding Compound - Science and Technology, Hanser Editora Hanser Publishers - Munique, 1993 
MACHADO, L. B. D., MATOS, J. R., Análise Térmica - Termogravimetria, in: CANEVAROLO , S. V. ed., Técnicas de Caracterização de Polímeros, Artliber Editora, 2004.

MARTINS, Eduardo Reginato, Comparação entre os desempenhos de faróis automotivos convencionais e aqueles que empregam diodos emissores de luz. São Paulo, 2005, 99 p. Dissertação (Mestrado em Engenharia Automotiva), Universidade de São Paulo, São Paulo, 2005

MAZUMDAR, Sanjay K., Composites manufacturing - materials, product and process engineering, Florida CRC Press, 2002

MEDINA, Heloisa Vasconcellos de, Plásticos automotivos: 0 desenvolvimento recente de novos polímeros e compósitos poliméricos na Renault, Revista Plástico Industrial Aranda Editora, Ano IV, número 48, Agosto de 2002, pp 108-120

MEYER, Clarisse Rinaldi, Implicações energético ambientais de esquemas de sucateamento de automóveis no Brasil, Tese de Doutorado, Universidade Federal do Rio de Janeiro, UFRJ- COPPE, 2001

MONK, J. F.; MORGAN, L. S., The manufacture of a new generation of headlamp reflectors, Proceedings of the Institution of Mechanical Engineers, 1985 vol. 199 pt 3, pp 181-188

ORMANJI, Wagner, RODOLFO Jr., Antonio; NUNES, Luciano Rodrigues; Tecnologia do PVC - 2ª . Ed., São Paulo: Braskem, 2002.

Pesquisas viabilizam a reciclagem de veículos ao final da vida - Plástico Industrial, n. 107 p.12, 13 e 15 abril de 2007.

PIVA, Ana Magda; WIEBECK, Hélio - Reciclagem do Plástico. Artliber Editora, São Paulo, 2004. 
Polímeros e a indústria automobilística - Polímeros vol.13 no. 2 São Carlos Abril/Junho 2003.

Plástico no Automóvel - Plástico Moderno n. 336, p. 08 a 18, outubro de 2006.

PRESTVÁCUO Catálogo On Line.

Disponível em: <http://www.prestvacuo.com.br/metalizadoras.asp $>$.

Acesso em: 05 mai 2009.

Produção de Veículos de 1957 a 2006 ANFAVEA.

Disponível em: <http://www.anfavea.com.br/anuario2007/Cap2 1 2007.pdf>. Acesso em: 26 set 2007.

Projeto reciclagem de resíduos sólidos - ABMACO - Associação Brasileira dos Materiais Compósitos -

Disponível em:<http://www.abmaco.org.br>.

Acesso em:18 set 2007.

ROSA, Ederson Nunes; CECONE, Eduardo Christiano; FRATTA, Fábio; ENZENBERG, Jarbas, Polímeros de alto desempenho aplicados a refletores, Trabalho de conclusão de curso de engenharia, Centro Universitário Fundação Santo André, 2008

SABIC Innovative Plastics.- Catálogo Técnico Poli (éter imida) PEI

Disponível em: <http://www.sabic.ip.com>. Acesso em 12 nov. 2009.

STRONG, A. Brent; Plastics - Materials and processing - New Jersey: Editora Prentice-Hall do Brasil, 1996

State of the art of plastic sorting and recycling: Feedback to vehicle design Froelich et al; - Le Bourget du Lac Cedex, France

Disponível em: <http://www.elsevier.com/locate/mineng>.

Acesso em: 19 dez 2006. 
ZAPAROLLI, Domingos, Injetoras e galvanoplastias buscam estratégias no concorrido mercado de cromação de plásticos - Revista Plástico Moderno, num. 407, p. 11-16, set. 2008. 


\section{Sugestão de trabalhos futuros}

- A granulometria reduzida do pó de BMC após a moagem sugere o estudo da incorporação desses resíduos em outras matérias primas tanto de plásticos quanto de borrachas.

- Outros teores de BMC poderiam ser incorporados ao PVC rígido e também no PVC flexível e avaliado a influência do mesmo nas propriedades do novo composto.

- Incorporação do BMC moído em outras formulações do próprio BMC. 